\title{
Traducción del fallo de la Corte Internacional de Justicia en los casos Ciertas actividades llevadas a cabo por Nicaragua en la zona fronteriza (Costa Rica c. Nicaragua) y Construcción de una carretera en Costa Rica a lo largo del río San Juan (Nicaragua c. Costa Rica) (Procedimientos acumulados)
}

\author{
Ricardo Abello Galvis*, Walter Arévalo Ramírez ${ }^{* *}$ \\ y Giovanny Vega Barbosa ${ }^{* * *}$
}

* Profesor principal de Derecho Internacional Público de la Facultad de Derecho de la Universidad del Rosario (Bogotá, Colombia); miembro de la Corte Permanente de Arbitraje (CPA) (2014-2019); M/Phil en Derecho Internacional y Relaciones Internacionales del Instituto de Altos Estudios Internacionales de Ginebra (IUHEI); estudiante de Doctorado en Ciencias Jurídicas de la Pontificia Universidad Javeriana; director/editor del ACDI, Anuario Colombiano de Derecho Internacional; expresidente de la Academia Colombiana de Derecho Internacional (Accoldi); asociado del Instituto Hispano Luso Americano de Derecho Internacional (IHLADI). Correo electrónico: ricardo.abello@urosario.edu.co

** Profesor de Derecho Internacional Público de la Facultad de Derecho de la Universidad del Rosario (Bogotá, Colombia); LLM (Master of Laws) en Derecho Internacional; asistente de investigación de la Stetson University College of Law (2014); especialista en Derecho Constitucional; abogado y politólogo (cum laude); investigador del Grupo de Investigación de Derecho Internacional de la Facultad de Jurisprudencia de la Universidad del Rosario; estudiante de Doctorado en Derecho de la Universidad del Rosario. Director de la Red Latinoamericana de Revistas de Derecho Internacional (Relaredi.org). Correo electrónico: walter.arevalo@urosario.edu.co

*** Abogado de la Universidad del Rosario. Profesor de Derecho Internacional Público de la Facultad de Derecho de la Universidad del Rosario (Bogotá, Colombia); asesor de la Oficina de Asuntos ante la Corte Internacional de Justicia (CIJ) del Ministerio de Relaciones Exteriores de Colombia. Correo electrónico: giovanny.vega@urosario.edu.co 
Nota: a continuación, se presenta una traducción no oficial al idioma español del texto de la sentencia proferida por la Corte Internacional de Justicia, el 16 de diciembre de 2015, en los casos Ciertas actividades llevadas a cabo por Nicaragua en la zona fronteriza (Costa Rica c. Nicaragua) y Construcción de una carretera en Costa Rica a lo largo del río San Juan (Nicaragua c. Costa Rica), casos objeto de acumulación procesal mediante orden del 17 de abril de 2013, en aplicación del artículo 47 del Reglamento de la Corte. El texto original de la sentencia puede ser consultado en la página web de la Corte, en la siguiente dirección: http://www.icj-cij.org. La presente traducción es exclusivamente para fines de divulgación y no tiene carácter oficial. No existe una versión oficial en español de las sentencias de la Corte, estas se emiten solo en sus idiomas oficiales, los cuales son, según el artículo 39-1 del Estatuto, el francés y el inglés. Además, según lo ordenado en el párrafo 2 del mismo artículo, en cada sentencia la Corte determina cuál es el idioma en el cual hace fe. En el caso de la sentencia del 16 de diciembre de 2015, este idioma es el francés. Por razones de espacio, no es posible incluir aquí el texto integral de las opiniones individuales y disidentes que algunos jueces decidieron añadir a la sentencia. Sin embargo, al final del presente texto, se incluyó la traducción de los resúmenes preparados por la Secretaría de la Corte.

Tabla de contenido

Cronología del procedimiento

Parágrafos

I. Jurisdicción de la Corte

II. Contexto histórico y geográfico y origen de las disputas $56-64$

III. Asuntos en el caso Costa Rica c. Nicaragua $65-144$

A. Soberanía sobre el territorio en disputa y presuntas violaciones conexas

B. Presuntas violaciones del derecho internacional ambiental

1. Obligaciones procedimentales

$101-112$
a) La presunta violación de la obligación de llevar a cabo un estudio de impacto ambiental
b) La presunta violación de la obligación de notificación y consulta
c) Conclusión

101-105 
2. Obligaciones sustanciales concernientes al daño transfronterizo

C. Cumplimiento de las medidas provisionales

121-129

D. Derechos de navegación

$130-136$

E. Reparación

137-144

IV. Asuntos en el caso Nicaragua c. Costa Rica

$145-228$

A. La presunta violación de obligaciones procedimentales

$146-172$

1. La presunta violación de la obligación de llevar a cabo un estudio de impacto ambiental

146-162

2. La presunta violación del artículo 14 del Convenio sobre la Diversidad Biológica

$163-164$

3. La presunta violación de la obligación de notificación y consulta

B. Presuntas violaciones de las obligaciones sustanciales

$174-223$

1. La presunta violación de la obligación de no causar daño transfronterizo significativo a Nicaragua

a) La contribución de sedimento de la carretera al río

b) Si el sedimento derivado de la carretera causó un daño significativo a Nicaragua

$187-216$

i. Presunto daño causado por el incremento en la concentración de sedimento en el río

ii. Presunto daño a la morfología del río, a la navegación y los programas de dragado nicaragüense

iii. Presunto daño a la calidad del agua y al ecosistema acuático

iv. Otros presuntos daños

c) Conclusión

2. Presuntas violaciones de las obligaciones convencionales

3. La obligación de respetar la integridad territorial de Nicaragua y su soberanía sobre el río San Juan 


\section{Corte Internacional de Justicia}

Año 2015

2015

16 de diciembre

Listado general

$\mathrm{N}^{\circ} 150$ y 152

\section{Ciertas actividades llevadas a cabo por Nicaragua en la zona fronteriza (Costa Rica c. Nicaragua) \\ $\mathrm{y}$}

Construcción de una carretera en Costa Rica a lo largo del río San Juan (Nicaragua c. Costa Rica)

Jurisdicción de la Corte

Contexto geográfico e histórico y origen de la disputa.

El río San Juan, el bajo río San Juan y el río Colorado - Isla Calero e Isla Portillos - Laguna de Harbor Head - Humedales de importancia internacional Tratado de Limites de 1858 - Laudo Cleveland - Laudos Alexander - Dragado del San Juan por Nicaragua - Actividades de Nicaragua en la parte norte de la Isla Portillos - Dragado de un canal (caño) y establecimiento de presencia militar Construcción de la ruta 1856 Juan Rafael Mora Porras (la carretera) por Costa Rica.

Asuntos en el caso Costa Rica c. Nicaragua.

Soberanía sobre el territorio en disputa - Definición del territorio en disputa - Descripción del límite en el Tratado de 1858 y los laudos Clevelandy AlexanderArtículos II y VI del Tratado de 1858 deben ser leídos conjuntamente — Soberanía sobre el banco derecho del río San Juan hasta donde se extiende su boca atribuida a Costa Rica - Referencia a "el primer canal que encuentra" en el primer laudo Alexander - Las imágenes aéreas y satelitales son insuficientes para probar que el caño existía antes del dragado de 2010 — Las declaraciones de oficiales nicaragüenses son insuficientes - El valor de los mapas y las efectividades es limitado - Las efectividades no pueden afectar el título soberano resultante del Tratado de 1858 y los laudos Clevelandy Alexander - La existencia del caño antes de 2010 se contradice 
con otra evidencia — La petición de Nicaragua impediría que Costa Rica disfrute de la soberanía territorial sobre el banco derecho del río San Juan hasta su boca — El banco derecho del caño no hace parte del limite - La soberania sobre el territorio disputado pertenece a Costa Rica.

Presuntas violaciones a la soberanía de Costa Rica - No se discute que Nicaragua escavó tres caños y estableció presencia militar en la zona en disputa - La soberanía territorial en Costa Rica fue violada - Obligación de reparar - No existen violaciones al artículo IX del Tratado de 1858 - no es necesario considerar una posible violación a la probibición del uso o amenaza de la fuerza - No es necesario considerar si la conducta de Nicaragua constituye una ocupación militar.

Presuntas violaciones del derecho internacional ambiental.

Obligaciones procedimentales - Obligación de conducir un estudio de impacto ambiental concerniente a las actividades que puedan causar daño transfronterizo significativo - El contenido del estudio de impacto depende de circunstancias especiales - Si el estudio confirma el riesgo de daño transfronterizo significativo, el Estado que planea la actividad requiere, de conformidad con la obligación de debida diligencia, notificarle y consultarle al Estado potencialmente afectado en tanto sea necesario para determinar las medidas apropiadas para mitigar el daño - El programa de dragado nicaragüiense no dio lugar al peligro de daño transfronterizo significativo - Nicaragua no requiere realizar un estudio de impacto ambiental transfronterizo - No existe una obligación bajo el derecho internacional general de notificar y consultar cuando no hay riesgo de daño transfronterizo significativo - No hay obligación convencional de consultar y notificar en el presente caso - La Corte concluye que Nicaragua no violó ninguna obligación procedimental.

Obligaciones sustantivas - Obligaciones especificas concernientes al rio San Juan en el Tratado de 1858 interpretadas en el laudo Cleveland - Obligación de derecho consuetudinario a ejercer la debida diligencia para prevenir daño transfronterizo significativo - No es ir a discutir la relación entre esas obligaciones en tanto no se estableció ningún daño - No hay prueba de que el dragado en el bajo río San Juan dañara bumedales costarricenses - No se aprecia que el programa de dragado causara una reducción significativa en la corriente del río Colorado - Cualquier desviación de agua debida al dragado no afectó seriamente la navegación en el río Colorado ni causó daño a Costa Rica — La Corte concluye que Nicaragua no violó ninguna obligación sustantiva. 
Cumplimiento de medidas provisionales - Nicaragua incumplió sus obligaciones bajo la orden del 8 de marzo de 2011 al excavar dos caños y establecer presencia militar en el territorio en disputa en 2013 - No se establece incumplimiento de obligaciones relativas a la orden de la Corte del 22 de noviembre de 2013.

Derechos de navegación - La petición es admisible - Articulo VI del Tratado de 1858 - Sentencia de la Corte en la disputa relativa a derechos de navegación y conexos - No es necesario que la Corte interprete el Decreto 079-2009 de Nicaragua - Cinco ocasiones de violación de derechos de navegación denunciadas por Costa Rica - Dos de las cinco ocasiones son estudiadas — La Corte concluye que Nicaragua violó los derechos de navegación de Costa Rica frente al Tratado de 1858 - No es necesario para la Corte estudiar los otros incidentes invocados por Costa Rica.

Reparación - La solicitud de ordenar repeler el Decreto 079-2009 y cesar las actividades del dragado no puede ser concedida - La declaración de incumplimiento provee una satisfacción adecuada para el daño no material sufrido - No se requieren garantías de no repetición - Costa Rica tiene derecho a compensación por el daño material — Las partes deben entablar negociaciones para el monto de la compensación - De no lograr un acuerdo en dos meses, la Corte determinará el monto a solicitud de una de las partes - Fallo de costas bajo el artículo 64 del estatuto no procede.

Asuntos en el caso Nicaragua c. Costa Rica.

Obligaciones procedimentales.

Presunta violación a la obligación de llevar a cabo un estudio de impacto ambiental - La obligación de debida diligencia requiere que el Estado establezca cuando una actividad propuesta implica el riesgo de daño transfronterizo significativo $-E l$ estudio de impacto ambiental es requerido cuando existe riesgo de daño - No hay evidencia de que Costa Rica determinara si un estudio de daño ambiental era necesario antes de la construcción de la vía - Gran escala del proyecto - Proximidad al río San Juan en territorio nicaragüense - Riesgo de erosión por deforestación - Posibilidad de desastres naturales en el área - Presencia de dos humedales de importancia internacional en el área - La construcción de la carretera implicaba un riesgo de daño 
transfronterizo significativo - No habia una emergencia que justificara la construcción inmediata de la vía - La Corte no debe decidir si en el derecho internacional existe una excepción por emergencia para la obligación de realizar un estudio de daño ambiental - Costa Rica se encuentra obligada a realizar el estudio de daño ambiental - La obligación requiere una evaluación ex ante del riesgo de daño transfronterizo significativo - Los diagnósticos ambientales y otros estudios de Costa Rica fueron evaluaciones post hoc — Costa Rica no cumplió con su obligación de realizar un estudio de impacto ambiental.

Presunta violación del artículo 14 del Convenio sobre la Diversidad Biológica - No se establece ninguna violación.

Presunta violación a la obligación de notificar y consultar - Deber en el derecho internacional general de notificar y consultar no requiere una declaración en este caso en tanto Costa Rica no ha realizado su estudio de impacto ambiental - Tratado de 1858 no impone la obligación a Costa Rica de notificar a Nicaragua la construcción de una carretera - No surgen obligaciones procedimentales de la Convención de Ramsar.

Obligaciones sustantivas.

Presunta violación a la obligación de ejercer la debida diligencia para prevenir causar daño transfronterizo significativo - Modelos y estimados de expertos sugieren que el sedimento, consecuencia de la construcción de la carretera, alcanza hasta el $2 \%$ de la carga total del río San Juan — Medidas actuales entregadas a la Corte no indican que la carretera bubiese impactado significativamente los niveles de sedimento en el rio - El incremento en los niveles de sedimento como resultado de la construcción de la carretera no es, en si mismo, la causa de daño transfronterizo significativo - No se establece daño significativo a la morfología del río a la navegación o al programa de dragado nicaragüiense - No hay prueba de daño significativo al ecosistema del río o a la calidad del agua — Los argumentos concernientes a otro tipo de daño no procederán.

Presuntas violaciones a obligaciones del tratado — No se establece ninguna violación.

Pretensión concerniente a la violación de la integridad y soberanía territorial - No se establece ninguna violación.

Reparación - Declaración de conducta ilícita respecto a la obligación de realizar un estudio de impacto ambiental es la medida apropiada de satisfacción - No hay bases para ordenar a Costa Rica cese de actos ilícitos - La restitución y compensación no son 
reparaciones adecuadas en ausencia de daño significativo - No es necesario nombrar un experto o comité para evaluar el daño - La solicitud de Nicaragua de ordenar a Costa Rica no realizar a futuro ningún desarrollo sin un estudio de impacto ambiental, no procede.

\section{Sentencia}

Presentes: presidente ABRAHAM; vicepresidente YUSUF; jueces OWADA, TOMKA, BENNOUNA, CANCADO TRINDADE, GREENWOOD, XUE, DONOGHUE, GAJA, SEBUTINDE, BHANDARI, ROBINSON, GEVORGLAN; jueces ad hoc GUILLAUME, DUGARD; secretario COUVREUR.

En el caso concerniente a "Ciertas actividades llevadas a cabo por Nicaragua en la zona fronteriza (Costa Rica c. Nicaragua)" y el caso acumulado (ver parágrafo 19) "Construcción de una carretera en Costa Rica a lo largo del río San Juan (Nicaragua c. Costa Rica)".

\section{Entre}

la República de Costa Rica, representada por

S. E. Sr. Manuel A. González Sanz, Ministro de Relaciones Exteriores y Culto de Costa Rica,

S. E. Sr. Édgar Ugalde Álvarez, Embajador en Misión Especial, como agentes;

S. E. Sr. Sergio Ugalde, Embajador de Costa Rica ante el Reino de los Países Bajos, miembro de la Corte Permanente de Arbitraje, como coagente, consejero y abogado;

Sr. Marcelo Kohen, profesor de Derecho Internacional del Graduate Institute of International and Development Studies, Ginebra, miembro del Institut de droit international,

Sr. Samuel Wordsworth, Q. C., miembro de la Barra Inglesa, miembro de la Barra de París, de las Cámaras de la Corte de Essex,

Sr. Arnoldo Brenes, Consejero Sénior del Ministerio de Relaciones Exteriores y Culto de Costa Rica, miembro de la Barra de Costa Rica, Sra. Kate Parlett, litigante admitida en Queensland, Australia, England y Wales,

Sra. Katherine del Mar, miembro de la Barra Inglesa, 4 New Square, Lincoln's Inn, como consejeros y abogados; 
Sr. Simon Olleson, miembro de la Barra Inglesa, 13 Old Square Chambers, como consejero;

Sr. Ricardo Otárola, Consejero Sénior del Ministerio de Relaciones Exteriores y Culto de Costa Rica,

Sra. Shara Duncan, Consejera Sénior del Ministerio de Relaciones Exteriores y Culto de Costa Rica,

Sr. Gustavo Campos, Ministro Consejero y Cónsul General de Costa Rica en el Reino de los Países Bajos,

Sr. Rafael Sáenz, Ministro Consejero en la Embajada de Costa Rica en el Reino de los Países Bajos,

Sra. Ana Patricia Villalobos, oficial del Ministerio de Relaciones Exteriores y Culto de Costa Rica,

como asistentes consejeros;

Sra. Elisa Rivero, asistente administrativa del Ministerio de Relaciones Exteriores y Culto de Costa Rica,

como asistente;

$\mathrm{y}$

la República de Nicaragua, representada por

S. E. Sr. Carlos José Argüello Gómez, Embajador de Nicaragua ante el Reino de los Países Bajos, como agente y consejero;

Sr. Stephen C. McCaffrey, profesor de Derecho Internacional en la Universidad del Pacífico, Escuela de Derecho McGeorge, Sacramento, exmiembro y expresidente de la Comisión de Derecho Internacional,

Sr. Alain Pellet, profesor de la Universidad de Paris Ouest, Nanterre-La Défense, exmiembro y expresidente de la Comisión de Derecho Internacional, miembro del Institut de droit international,

Sr. Paul S. Reichler, abogado, Foley Hoag LLP, miembro de la Barra de la Suprema Corte de Estados Unidos y el Distrito de Columbia,

Sr. Andrew B. Loewenstein, abogado, Foley Hoag LLP, miembro de la Barra de la Mancomunidad de Massachussetts, como consejeros y abogados; 
Sr. César Vega Masís, Ministro Diputado de Relaciones Exteriores, Dirección de Asuntos Jurídicos, Soberanía y Territorio, Ministerio de Relaciones Exteriores de Nicaragua,

Sr. Walner Molina Pérez, asesor jurídico, Ministerio de Relaciones Exteriores de Nicaragua,

Sr. Julio César Saborío, asesor jurídico, Ministerio de Relaciones Exteriores de Nicaragua,

como consejeros;

Sr. Edgardo Sobenes Obregón, consejero, Embajada de Nicaragua ante el Reino de los Países Bajos,

Sra. Claudia Loza Obregón, Primera Secretaria, Embajada de Nicaragua ante el Reino de los Países Bajos,

Sr. Benjamin Samson, investigador, Centre de droit international de Nanterre (CEDIN), University of Paris Ouest, Nanterre — La Défense,

Sra. Cicely O. Parseghian, abogada, Foley Hoag LLP, miembro de la Barra de la Mancomunidad de Massachussetts,

Sr. Benjamin K. Guthrie, abogado, Foley Hoag LLP, miembro de la Barra de la Mancomunidad de Massachussetts,

Sr. Ofilio J. Mayorga, abogado, Foley Hoag LLP, miembros de las Barras de Nueva York y Nicaragua,

como consejeros asistentes;

Sr. Danny K. Hagans, principal científico terrestre en Pacific Watershed Associates, Inc.,

Sr. Robin Cleverly, consultor geográfico y técnico,

Sra. Blanca P. Ríos Touma, PhD, profesora asistente en la Universidad Tecnológica de Indoamérica de Quito, Ecuador,

Sr. Scott P. Walls, maestro de Arquitectura Paisajista y Planeación Ambiental, propietario y geomorfologista fluvial en Scott Walls Consulting, ecohidrologista en CBEC Ecoengineering, Inc., y principal oficial financiero y manager de proyecto en International Watershed Partners,

Sra. Victoria Leader, consultora geográfica y técnica, como asesores científicos y expertos.

La Corte, compuesta según se indicó arriba, tras deliberar profiere la siguiente sentencia: 
1. Por demanda registrada ante la Secretaría de la Corte el 18 de noviembre de 2010, la República de Costa Rica (en adelante Costa Rica) instituyó procedimientos contra la República de Nicaragua (en adelante Nicaragua) en el caso concerniente a "Ciertas actividades llevadas a cabo por Nicaragua en la zona fronteriza (Costa Rica c. Nicaragua)" (en adelante Costa Rica c. Nicaragua). En la demanda, Costa Rica alega en particular que Nicaragua invadió y ocupó territorio costarricense, y que, posteriormente, excavó un canal: más adelante, reprocha a Nicaragua el conducir trabajos (especialmente dragar el río San Juan) en violación de sus obligaciones internacionales.

2. En su demanda, Costa Rica invoca como base de la jurisdicción de la Corte el artículo XXXI del Tratado Americano de Solución Pacífica de Controversias, adoptado en Bogotá el 30 de abril de 1948 (en adelante, Pacto de Bogotá). Adicionalmente, Costa Rica busca encontrar la jurisdicción de la Corte en la declaración realizada el 20 de febrero de 1973 bajo el artículo 36, parágrafo 2, del Estatuto, como también en declaraciones que Nicaragua realizó el 24 de septiembre de 1929 (y enmendó el 23 de octubre de 2001) bajo el artículo 36 del Estatuto de la Corte Permanente Internacional de Justicia y que es considerado, bajo el artículo 36, parágrafo 5 , de la presente Corte, por el período en que siga vigente, como aceptación de la jurisdicción obligatoria de esta Corte.

3. El 18 de noviembre de 2010, habiendo presentado su demanda, Costa Rica también remitió una solicitud de medidas provisionales, bajo el artículo 41 del Estatuto y los artículos 73, 74, 75 del Reglamento de la Corte.

4. En concordancia con el artículo 40, parágrafo 2, del Estatuto, el Secretario comunicó al gobierno de Nicaragua una copia firmada de la demanda, y, bajo el parágrafo 3 del mismo artículo, todos los Estados con derecho a presentarse a la Corte fueron notificados de la presentación de la demanda.

5. Bajo las instrucciones de la Corte según el artículo 43 del Reglamento de la Corte, el Secretario se comunicó con los Estados partes de la Convención Relativa a los Humedales de Importancia Internacional especialmente como Hábitat de Aves Acuáticas, firmada en Ramsar el 2 de febrero de 1971 (en adelante Convención de Ramsar), para la notificación provista en el artículo 63, parágrafo 1, del Estatuto.

6. En tanto la Corte no presenta ningún juez de la nacionalidad de las partes en el estrado, cada una de ellas, en ejercicio del derecho conferido por el artículo 31, parágrafo 3, del Estatuto, eligió a un juez ad hoc 
para el caso. Costa Rica seleccionó al Sr. John Dugard y Nicaragua, al Sr. Gilbert Guillaume.

7. Por orden del 8 de marzo de 2011 (en adelante orden del 8 de marzo de 2011), la Corte, habiendo escuchado a las partes, indicó medidas provisionales destinadas a ambas partes. La Corte también solicitó a ambas partes informarle sobre el cumplimiento de las medidas provisionales. Mediante varias comunicaciones, ambas partes notificaron a la Corte de las medidas que habían tomado en referencia a la orden anteriormente mencionada y realizaron observaciones acerca del cumplimiento de la otra parte respecto a dicha orden.

8. Por orden del 5 de abril de 2011, la Corte fijó el 5 de diciembre de 2011 y el 6 de agosto de 2012 como los respectivos plazos para la presentación del memorial por Costa Rica y una contramemoria de Nicaragua. El memorial y la contramemoria fueron presentados dentro de los límites anteriormente prescritos.

9. Por medio de una demanda presentada ante la Secretaría el 22 de diciembre de 2011, Nicaragua instituyó procedimientos contra Costa Rica en el caso concerniente a "Construcción de una carretera en Costa Rica a lo largo del río San Juan (Nicaragua c. Costa Rica)" (en adelante "caso Nicaragua c. Costa Rica"). En su demanda, Nicaragua indica que el caso es relativo a la "violación de la soberanía nicaragüense y daños ambientales mayores en su territorio", sosteniendo, en particular, que Costa Rica estaba desarrollando grandes obras de construcción vial en el área de la frontera entre los dos países a lo largo del río San Juan, en violación a varias obligaciones internacionales y con graves consecuencias ambientales.

10. En su demanda, Nicaragua invoca el artículo XXXI del Pacto de Bogotá como base de la jurisdicción ante la Corte. Adicionalmente, Nicaragua busca fundar la jurisdicción de la Corte en las ya mencionadas declaraciones, aceptando la jurisdicción de la Corte (ver parágrafo 2).

11. De acuerdo con el artículo 40, parágrafo 2, del Estatuto, el Secretario comunicó una copia firmada de la demanda al gobierno de Costa Rica, y, bajo el parágrafo 3 de tal artículo, todos los Estados titulados a comparecer ante la Corte fueron notificados de la demanda.

12. Siguiendo las instrucciones de la Corte bajo el artículo 43 de su Reglamento, el Secretario envío las notificaciones provistas en el artículo 63, parágrafo 1, del Estatuto, a los Estados partes de la Convención de Ramsar, el Convenio de 1992 sobre la Diversidad Biológica y la Convención de 1992 para la Conservación de la Biodiversidad y Protección Prioritaria de Áreas de Vida Salvaje en América Central. 
13. En tanto la Corte no incluye jueces de la nacionalidad de las partes en el estrado, cada uno de ellos, en ejercicio del derecho conferido por el artículo 31, parágrafo 3, del Estatuto, seleccionó a un juez ad hoc para el caso. Nicaragua seleccionó al Sr. Gilbert Guillaume y Costa Rica, al Sr. Bruno Simma.

14. Por orden del 23 de enero de 2012, la Corte fijó el 19 de diciembre de 2012 y el 19 de diciembre de 2013 como los respectivos plazos para la presentación del memorial y de la contramemoria por Nicaragua y Costa Rica, respectivamente. El memorial y la contramemoria fueron presentados dentro del tiempo prescrito.

15. En la contramemoria presentada en el caso Costa Rica c. Nicaragua, el 6 de agosto de 2012, Nicaragua presentó cuatro pretensiones reconvencionales. En la primera pretensión reconvencional, solicitó a la Corte que declare que "Costa Rica es responsable frente a Nicaragua" por "la inhabilitación y posible destrucción de la navegabilidad del río San Juan causada por la construcción de la vía". En su segunda pretensión reconvencional, solicitó a la Corte que declarará que "se ha convertido en el único soberano en el área anteriormente ocupada por la bahía del San Juan del Norte". En su tercera pretensión reconvencional, solicitó a la Corte encontrar que "Nicaragua tiene un derecho de libre navegación en el Colorado... hasta que las condiciones de navegabilidad existentes para la época en que se concluyó el Tratado de 1858 se restablezcan". Finalmente, en su cuarta pretensión reconvencional, Nicaragua sostiene que Costa Rica violó las medidas provisionales indicadas por la Corte en su orden del 8 de marzo de 2011.

16. En la audiencia entre el Presidente con los representantes de las partes el 19 de septiembre de 2012, estas acordaron no solicitar a la Corte la autorización para presentar una réplica y una dúplica en el caso Costa Rica c. Nicaragua. En la misma reunión, el coagente de Costa Rica elevó ciertas objeciones a la admisibilidad de las tres primeras pretensiones reconvencionales contenidas en la contramemoria de Nicaragua. El confirmó estas objeciones el mismo día.

Por cartas del 28 de septiembre de 2012, el Secretario informó a las partes que la Corte había fijado el 30 de noviembre de 2012 y el 30 de enero de 2013 como los respectivos plazos para la presentación de las observaciones escritas por Costa Rica y Nicaragua sobre la admisibilidad de las, en su momento, tres primeras pretensiones reconvencionales. Ambas partes presentaron sus observaciones dentro del plazo prescrito. 
17. Por cartas del 19 de diciembre de 2012, que acompañaron su memorial en el caso Nicaragua c. Costa Rica, Nicaragua solicitó a la Corte "decidir proprio motu si las circunstancias del caso requerían de medidas provisionales" y considerar si existía la necesidad de unir los procedimientos en los casos Nicaragua c. Costa Rica y Costa Rica c. Nicaragua.

Por Carta del 15 de enero de 2013, el Secretario, actuando bajo instrucción del Presidente, solicitó a Costa Rica informarle a la Corte, para el 18 de febrero de 2013 a lo sumo, sus opiniones sobre ambas cuestiones. Costa Rica comunicó sus opiniones en el plazo debido.

18. Por cartas del 11 de marzo de 2013, el Secretario informó a las partes que la Corte consideraba que las circunstancias en el caso Nicaragua c. Costa Rica, como se presentaban en el momento, no eran tales para requerir el ejercicio de su poder bajo el artículo 75 del Reglamento, para indicar medidas provisionales proprio motu.

19. Por dos órdenes separadas del 17 de abril de 2013, la Corte unió los procedimientos en los casos Costa Rica c. Nicaragua y Nicaragua c. Costa Rica.

20. Por comunicación de la misma fecha, el Sr. Simma, quien había sido seleccionado por Costa Rica como juez ad hoc en el caso Nicaragua c. Costa Rica, informó a la Corte su decisión de renunciar a sus funciones, tras la unión de los procedimientos. Así bien, los jueces Guillaume y Dugard participaron como jueces ad hoc en los casos conjuntos (ver parágrafos 6 y 13).

21. Por orden del 18 de abril de 2013, la Corte decidió sobre la admisibilidad de las pretensiones reconvencionales de Nicaragua en el caso Costa Rica c. Nicaragua. Esta concluyó que no existía la necesidad de decidir sobre la admisibilidad de la primera pretensión reconvencional de Nicaragua. Encontró las segundas y terceras pretensiones reconvencionales inadmisibles. La Corte también encontró que no había necesidad de estudiar la cuarta demanda reconvencional y que las partes podían llevar cualquier pregunta relativa a la implementación de las medidas provisionales indicadas por la Corte en su orden del 8 de marzo de 2011 a los siguientes pasos del procedimiento.

22. En mayo 23 de 2013, Costa Rica, en referencia al artículo 41 del Estatuto y el artículo 76 del Reglamento de la Corte, presentó ante el Secretario una solicitud para la modificación de la orden de medidas provisionales del 8 de marzo de 2011. En sus observaciones escritas seguidamente, de fecha del 14 de junio de 2013, Nicaragua solicitó a la Corte que rechazará la petición de Costa Rica, a su turno solicitando a la Corte que, de 
otro lado, modificará la orden del 8 de marzo de 2011 bajo el artículo 76 del Reglamento. Costa Rica comunicó a la Corte sus observaciones escritas sobre la solicitud de Nicaragua el 20 de junio de 2013.

23. Por orden del 16 de julio de 2013, la Corte encontró que "las circunstancias, como se presentan hoy ante la Corte, no son tales como para requerir un ejercicio de su poder de modificar las medidas indicadas en la orden de 2011". La Corte reafirmó lo dicho en las medidas provisionales.

24. Para el 24 de septiembre de 2013, Costa Rica, en referencia al artículo 41 del Estatuto y a los artículos 73, 74 y 75 del Reglamento, presentó ante el Secretario una solicitud para la toma de nuevas medidas provisionales en el caso Costa Rica c. Nicaragua.

25. El 11 de octubre de 2013, Nicaragua presentó ante la Secretaría una solicitud de toma de medidas provisionales en el caso Nicaragua c. Costa Rica. Nicaragua sugirió que su solicitud fuera estudiada concurrentemente con la solicitud de Costa Rica para la toma de nuevas medidas provisionales en el caso Costa Rica c. Nicaragua, en un único procedimiento oral. Por carta del 14 de octubre de 2013, Costa Rica objetó la sugerencia de Nicaragua. Por carta del 14 de octubre de 2013, el Secretario informó a las partes que la Corte había decidido considerar las solicitudes de manera separada.

26. Por orden del 22 de noviembre de 2013, dentro del caso Costa Rica c. Nicaragua, la Corte, habiendo escuchado a las partes, reafirmó las medidas provisionales indicadas en su orden del 8 de marzo de 2011 e indicó nuevas medidas provisionales dirigidas a las dos partes. La Corte también dio instrucciones a las partes de informarle, en intervalos trimestrales, sobre el cumplimiento de las medidas provisionales. Mediante varias comunicaciones, cada una de las partes notificó a la Corte de las medidas que habían tomado en referencia a la mencionada orden e hicieron observaciones sobre el cumplimiento de la otra parte de dicha orden.

27. Por orden del 13 de diciembre de 2013, en el caso Nicaragua c. Costa Rica, la Corte, tras escuchar a las partes, encontró que "las circunstancias, como se presentan hoy ante la Corte, no son tales para requerir el ejercicio del poder bajo el artículo 41 del Estatuto para indicar medidas provisionales".

28. En reunión sostenida entre el Presidente y representantes de las partes el 22 de enero de 2014, Nicaragua solicitó a la Corte autorizar una segunda ronda de argumentos escritos en el caso Nicaragua c. Costa Rica, lo que fue objetado por Costa Rica. Por orden del 3 de febrero de 2014, la Corte autorizó la remisión de una réplica de Nicaragua y una dúplica de Costa Rica, y fijó el 4 de agosto de 2014 y el 2 de febrero de 2015 como 
los respectivos plazos de presentación. La réplica de Nicaragua y dúplica de Costa Rica fueron presentadas dentro del plazo prescrito.

29. Por cartas del 2 de abril de 2014, el Secretario informó a las partes que la Corte, en concordancia con el artículo 54, parágrafo 1, del Reglamento de la Corte, había fijado el 3 de marzo de 2015 como la fecha de apertura de los procedimientos orales en los casos conjuntos.

30. En carta del 4 de agosto de 2014, que acompaña su réplica en el caso Nicaragua c. Costa Rica, Nicaragua sugirió a la Corte designar un "experto neutral bajo los artículos 66 y 67 del Reglamento". Por carta del 14 de agosto de 2014, Costa Rica indicó que consideraba "que no existían bases para que la Corte ejerciera su poder de designar un experto como lo solicitaba Nicaragua".

31. Por carta fechada del 15 de octubre de 2014, Nicaragua solicitó que la apertura de los procedimientos orales en los casos conjuntos fuera pospuesta hasta mayo de 2015. Teniendo en cuenta que Costa Rica había manifestado en su carta del 14 de agosto de 2014, referida en el párrafo anterior, que la evidencia enviada por las partes "habría de ser adicionada y completada" en su dúplica en el caso Nicaragua c. Costa Rica, Nicaragua expresó su opinión de que sería "inadecuado e inequitativo para ella, tener menos de un mes para analizar y responder a la nueva evidencia científica y reportes de expertos presentados por Costa Rica". Por carta del 20 de octubre de 2014, Costa Rica se opuso a esta solicitud, argumentando que cualquier dilación de la Corte en cuanto a escuchar y juzgar el caso Costa Rica c. Nicaragua sería perjudicial para Costa Rica, que Nicaragua tuvo tiempo suficiente para analizar la dúplica y formular su respuesta antes del inicio de las audiencias, y que la solicitud de Nicaragua era extemporánea. Por cartas del 17 de noviembre de 2014, el Secretario informó a las partes que la Corte había decidido posponer la fecha de apertura de los procedimientos orales en los casos conjuntos para el 14 de abril de 2015.

32. Por cartas del 5 de diciembre de 2015, relativas a las comunicaciones mencionadas en el parágrafo 30, el Secretario informó a las partes que la Corte encontraría útil que, durante el curso de las audiencias en los dos casos, esta pudiera llamar a los expertos cuyos reportes fueron anexados a los argumentos escritos, en particular el Sr. Throne y el Sr. Kondolf. El Secretario también indicó que la Corte agradecería si, para el 15 de enero de 2015 a más tardar, las partes presentaran sugerencias relativas a las modalidades de interrogatorio para esos expertos. Estas sugerencias fueron recibidas de Nicaragua en el plazo debido. Por carta del 20 de enero de 2015, Costa Rica comentó las sugerencias de Nicaragua. 
33. Por carta del 2 de febrero de 2015, que acompaña su dúplica en el caso Nicaragua c. Costa Rica, Costa Rica eleva la posibilidad de una visita al "lugar de la carretera". Por carta del 10 de febrero de 2015, Nicaragua expresó su afabilidad de asistir en la medida de lo posible en la organización "de tal visita a lugar de la carretera y al río San Juan de Nicaragua". También reiteró su propuesta de que la Corte designara un experto (ver parágrafo 30) para evaluar la construcción de la carretera y sugirió que el experto fuera incluido en la delegación de la Corte para cualquier visita al terreno. Por carta del 11 de febrero de 2015, Costa Rica comentó la carta de Nicaragua del 10 de febrero de 2015, indicando que la designación de un experto era innecesaria. Por carta del 25 de febrero de 2015, el Secretario indicó a las partes que la Corte había decidido no hacer una visita al terreno.

34. Por cartas del Secretario, fechadas el 4 de febrero de 2015, las partes fueron informadas de que deberían indicar a la Corte, para el 2 de marzo de 2015, los nombres de los expertos que intentaban presentar, y comunicar la información requerida por el artículo 57 del Reglamento. A las partes también se les solicitó proveer a la Corte, para el 16 de marzo de 2015, las declaraciones escritas de esos expertos (limitadas a un resumen de los reportes del experto o sus observaciones de reportes de otros expertos en el expediente del caso) y fueron informadas que estas reemplazarían el interrogatorio principal. Adicionalmente, la Corte invitó a las partes a llegar a un acuerdo acerca de la distribución del tiempo para el interrogatorio cruzado y el contrainterrogatorio de los expertos, para el 16 de marzo de 2015.

Por las mismas cartas, el Secretario también notificó a las partes de los siguientes detalles relativos al proceso de interrogatorio de expertos. Tras hacer una declaración solemne requerida bajo el artículo 64 del Reglamento, el experto será llamado por la parte que lo solicita a sustentar su declaración escrita. La otra parte entonces tendrá la oportunidad de hacer un interrogatorio cruzado sobre los contenidos de la declaración escrita o sus reportes. Un contrainterrogatorio será posteriormente permitido, pero solo limitado a elementos que surgieran del interrogatorio cruzado. Finalmente, los jueces tendrán la oportunidad de presentarle sus preguntas al experto.

35. Por cartas del 2 de marzo de 2015, las partes indicaron los nombres de los expertos que deseaban presentar en las audiencias, y entregaron la otra información concerniente a lo requerido por el artículo 57 del Reglamento (parágrafo 34). 
36. Bajo una carta fechada el 3 de marzo de 2015, Costa Rica comunicó a la Corte un video que deseaba fuera incluido en el expediente para ser presentado en las audiencias. Por carta del 13 de marzo de 2015, Nicaragua declaró que no tenía objeciones a la solicitud de Costa Rica y presentó ciertos comentarios a la utilidad del video. También anuncio que en respuesta presentaría algunas fotografías. Por cartas del 23 de marzo de 2015, el Secretario informó a las partes que la Corte había admitido la solicitud de Costa Rica.

37. Por carta del 15 de marzo de 2015, las partes comunicaron las declaraciones escritas de los expertos que pretendían presentar en las audiencias. Costa Rica también le solicitó a la Corte extender al 20 de marzo el plazo dentro del cual las partes podían presentar un acuerdo acerca del tiempo destinado para el interrogatorio cruzado y el contrainterrogatorio de los expertos, lo que fue aceptado por la Corte. Aun así, en tanto las partes no pudieron ponerse de acuerdo plenamente en esta materia dentro del plazo extendido, el Secretario les informó, por cartas del 23 de marzo de 2015, de la decisión de la Corte respecto al tiempo máximo que podría ser utilizado para los interrogatorios. En este ámbito, se invitó a las partes a indicar el orden en que deseaban presentar a los expertos y el tiempo preciso que deseaban reservar para el interrogatorio cruzado de los expertos llamados por la contraparte, lo que hicieron en cartas del 30 de marzo y el 2 de abril de 2015. Por cartas del 10 de abril de 2015, el Secretario comunicó a las partes el programa detallado para el interrogatorio de expertos según lo adoptado por la Corte.

38. Por cartas del 23 de marzo de 2015, el Secretario informó a las partes que, en relación con el caso Nicaragua c. Costa Rica, la Corte deseaba que cada uno presentará, para el 10 de abril de 2015, un mapa donde apareciera el río San Juan y la carretera construida por Costa Rica, y que indicara las ubicaciones precisas discutidas en los estudios referidos en las declaraciones escritas provistas a la Corte el 16 de marzo de 2015 (ver parágrafo 37). Bajo cartas del 10 de abril de 2015, Nicaragua y Costa Rica presentaron a la Corte las versiones impresa y electrónica de los mapas que prepararon.

39. Por carta del 23 de marzo de 2015, Nicaragua, según lo anunciado (parágrafo 36), entregó a la Corte las fotografías que deseaba se incluyeran en el expediente del caso. Por carta del 31 de marzo de 2015, Costa Rica informó a la Corte que no tenía ninguna objeción a la solicitud de Nicaragua. Por carta del 8 de abril de 2015, el Secretario informó a las partes que la Corte aceptaba la solicitud de Nicaragua. 
40. Por carta del 13 de abril de 2015, Costa Rica solicitó que Nicaragua presentara una copia del reporte de la Misión de Asesoramiento 72 de Ramsar, en relación con el Refugio de Vida Silvestre Río San Juan (Nicaragua). Por Carta del 16 de abril de 2015, Nicaragua indicó que se encontraba en posesión de tan solo un reporte preliminar, en español, que adjuntó a su carta. Subsecuentemente, bajo carta del 24 de abril de 2015, Nicaragua transmitió a la Corte los comentarios que había remitido el 30 de noviembre de 2011 al reporte preliminar de la Misión de Asesoramiento de Ramsar (original en español y extractos en inglés), como también una respuesta del Secretario de Ramsar del 19 de diciembre de 2011 (versión en español únicamente). Las partes posteriormente entregaron a la Corte las traducciones en inglés de los documentos presentados en español por Nicaragua.

41. Por carta del 21 de abril de 2015, el Secretario informó a las partes que la Corte había decidido solicitar, bajo el artículo 62 del Reglamento, que Nicaragua presentara el texto completo de ambos documentos, de los cuales algunos extractos fueron anexados en su contramemoria en el caso Costa Rica c. Nicaragua. Por carta del 24 de abril de 2015, Nicaragua comunicó a la Corte el texto completo de las versiones en español de los documentos requeridos. Traducciones certificadas al inglés fueron presentadas por Nicaragua en carta del 15 de mayo de 2015.

42. Por carta del 28 de abril de 2015, Costa Rica solicitó que se incluyeran fotografías en el caso Nicaragua c. Costa Rica. En carta del 29 de abril de 2015, Nicaragua objetó la solicitud, que consideró tardía. Por cartas del 29 de abril de 2015, el Secretario informó a las partes que la Corte había decidido no conceder la solicitud a Costa Rica.

43. Según el artículo 53, parágrafo 2, del Reglamento, tras identificar la opinión de las partes, la Corte decidió que copias de los argumentos orales y de los documentos anexos serían entregadas al público durante la apertura de los procedimientos orales.

44. Las audiencias públicas se llevaron a cabo en los casos conjuntos del 14 de abril de 2015 al 1 de mayo de 2015. Entre el 14 y 17 de abril y el 28 y 29 de abril de 2015, las audiencias se enfocaron en el caso Costa Rica c. Nicaragua, entre el 20 y 24 de abril y el 30 de abril y el 1 de mayo, en el caso Nicaragua c. Costa Rica. La Corte escuchó las audiencias y respuestas de: 
En el caso Costa Rica c. Nicaragua, por Costa Rica:

S. E. Sr. Édgar Ugalde Álvarez,

S. E. Sr. Sergio Ugalde,

Sr. Arnoldo Brenes,

Sr. Samuel Wordsworth,

Sr. Marcelo Kohen,

Sra. Kate Parlett,

Sra. Katherine del Mar.

Por Nicaragua:

S. E. Sr. Carlos José Argüello Gómez,

Sr. Alain Pellet,

Sr. Paul S. Reichler,

Sr. Andrew B. Loewenstein,

Sr. Stephen C. McCaffrey.

En el caso Nicaragua c. Costa Rica,

por Nicaragua:

S. E. Sr. Carlos José Argüello Gómez,

Sr. Paul S. Reichler,

Sr. Andrew B. Loewenstein,

Sr. Stephen C. McCaffrey,

Sr. Alain Pellet.

Por Costa Rica:

S. E. Sr. Édgar Ugalde Álvarez,

Sr. Arnoldo Brenes,

Sra. Katherine del Mar,

Sr. Marcelo Kohen,

Sr. Samuel Wordsworth,

Sra. Kate Parlett,

S. E. Sr. Sergio Ugalde.

45. En el caso Costa Rica c. Nicaragua, Costa Rica llamó al Sr. Throne como experto durante la audiencia pública del 14 de abril de 2015 (tarde). Posteriormente, durante la audiencia pública del 17 de abril de 2015 (mañana) Nicaragua llamó a los siguientes expertos: Sr. Van Rhee y Sr. Kondolf. En el caso Nicaragua c. Costa Rica, Nicaragua llamó a los siguientes 
expertos durante las audiencias públicas del 20 de abril (mañana y tarde): Sr. Weaver, Sr. Kondolf, Sr. Andrews y Sr. Sheate. Costa Rica llamó al Sr. Cowx y al Sr. Thorne como expertos durante la audiencia pública del 24 de abril de 2015 (mañana). Algunos jueces formularon preguntas a los expertos, que respondieron oralmente.

46. En las audiencias, miembros de la Corte realizaron preguntas a las partes, que dieron sus respuestas oralmente, según el artículo 61, parágrafo 4, del Reglamento.

47. En su demanda en el caso Costa Rica c. Nicaragua, Costa Rica formuló las siguientes pretensiones:

Por tales razones, y reservándose el derecho a complementar, amplificar o enmendar la presente demanda, Costa Rica solicita a la Corte que juzgue y declare que Nicaragua se encuentra en violación de sus obligaciones internacionales según lo referido en el parágrafo 1 de la presente demanda en lo relativo a la incursión y ocupación de territorio costarricense. El serio daño infligido a sus selvas y pantanos protegidos, y el daño sobre el río Colorado, sus humedales y ecosistemas protegidos, como también en las actividades de dragado y canalización realizadas por Nicaragua en el río San Juan.

En particular, se le solicita a la Corte que juzgue y declare que, por esta vía, Nicaragua ha violado:

a) El territorio de la República de Costa Rica, en lo convenido y delimitado por el Tratado de Límites de 1858, el laudo Cleveland y el primer y segundo laudo Alexander;

b) Los principios fundamentales de integridad territorial y la prohibición del uso de la fuerza según la Carta de las Naciones Unidas y la Carta de la Organización de los Estados Americanos;

c) La obligación en cabeza de Nicaragua por el artículo IX del Tratado de 1858 de Límites frente a no usar el río San Juan para actos hostiles;

d) La obligación de no dañar el territorio de Costa Rica;

e) La obligación de no canalizar artificialmente el río San Juan fuera de su curso natural sin el consentimiento de Costa Rica; 
f) La obligación de no prohibir la navegación del río San Juan por nacionales costarricenses;

g) La obligación de no dragar el río San Juan si esto causa daño al territorio de Costa Rica (incluyendo el río Colorado), según el laudo Cleveland de 1888;

h) Las obligaciones bajo la Convención de Ramsar en materia de humedales;

i) La obligación de no agravar y extender la disputa mediante la adopción de medidas contra Costa Rica, incluyendo la expansión del territorio costarricense invadido y ocupado, o al adoptar cualquier otra medida o llevar a cabo futuras acciones que infrinjan la integridad territorial de Costa Rica según el derecho internacional.

Costa Rica también solicitó a la Corte que "determine la reparación que debe realizar Nicaragua, en particular en relación con cualquier medida referida a las pretensiones anteriores".

48. En el curso de los procedimientos escritos en el caso Costa Rica c. Nicaragua, las siguientes pretensiones fueron presentadas por las partes:

En nombre del gobierno de Costa Rica, en el memorial:

Por tales razones, y reservándose el derecho a adicionar, amplificar o enmendar las presentes pretensiones:

1. Costa Rica solicita a la Corte que juzgue y declare que, por su conducta, Nicaragua ha violado:

a) La obligación de respetar la soberanía e integridad territorial de la República de Costa Rica, dentro de los límites establecidos por el Tratado de Límites de 1858 y posteriormente definidos por la Comisión de Demarcación establecida por la Convención Pacheco-Matus, en particular por el primer y segundo laudo Alexander;

b) La prohibición del uso de la fuerza bajo el artículo 2(4) de la Carta de las Naciones Unidas y los artículos 10, 19 y 21 de la Carta de la Organización de Estados Americanos;

c) La obligación de Nicaragua bajo el artículo XI del Tratado de Límites de 1858 de no usar el río San Juan para realizar actos hostiles; 
d) Los derechos de los nacionales de Costa Rica a la libre navegación en el río San Juan según el Tratado de Límites de 1858, el laudo Cleveland y la sentencia de la Corte del 13 de julio de 2009;

e) La obligación de no dragar, desviar o alterar el curso del río San Juan, o conducir ningún otro tipo de trabajo en el río, si este causa daño al territorio costarricense (incluyendo el río Colorado), su medio ambiente, o los derechos de Costa Rica según el laudo Cleveland;

f) La obligación de consultar a Costa Rica acerca de la implementación de las obligaciones surgidas de la Convención de Ramsar, en particular la obligación de coordinar políticas y regulaciones futuras en materia de conservación de humedales y su flora y fauna, bajo el artículo 5(1) de la Convención de Ramsar; y

g) La orden de la Corte sobre medidas provisionales del 8 de marzo de 2011.

Y subsecuentemente juzgar y declarar que Nicaragua está:

h) Obligada a cesar estas violaciones y hacer las reparaciones correspondientes.

2. A la Corte se le solicita, en consecuencia, que ordene que Nicaragua:

a) Retire toda presencia, incluyendo tropas y otro personal (civil, policial, de seguridad o voluntario), de aquella parte de Costa Rica conocida como Isla Portillos, en el banco derecho del río San Juan, y prevenir el regreso de cualquiera de este personal;

b) Cese toda actividad de dragado en el río San Juan, en el área entre el punto de bifurcación del río Colorado y el río San Juan y en la desembocadura del río San Juan en el mar Caribe, aguardando:

i. Un estudio de impacto ambiental adecuado;

ii. La notificación a Costa Rica de futuros planes de dragado para el área, no menos de tres meses antes de la ejecución de dichos planes;

iii. La debida consideración de cualquier comentario de Costa Rica realizada durante el período de un mes posterior a la notificación.

c) No conduzca ninguna operación de dragado u otros trabajos en el área en tanto estos puedan causar daño significativo al territorio de Costa Rica (incluyendo el río Colorado) o su me- 
dio ambiente, o perjudiquen los derechos de Costa Rica bajo el laudo Cleveland.

3. A la Corte también se le solicita que determine, en una fase separada, la reparación y satisfacción que debe realizar Nicaragua.

\section{En nombre del gobierno de Nicaragua,} en su contramemoria:

Por las razones expresadas anteriormente, la República de Nicaragua solicita a la Corte:

1. Desestimary rechazar las pretensiones y solicitudes de Costa Rica en su demanda;

2. Juzgar y declarar que:

i. Nicaragua goza de soberanía plena sobre el caño que une la laguna de Harbor Head con el río San Juan, cuyo banco derecho constituye el límite territorial, como lo estableció el Tratado de 1858, interpretado por el laudo Cleveland y los laudos Alexander;

ii. Costa Rica tiene la obligación de respetar la soberanía y la integridad territorial de Nicaragua, dentro de los límites establecidos por el Tratado de Límites de 1858, interpretado por el laudo Cleveland y los laudos Alexander;

iii. Nicaragua tiene derecho, en concordancia con el Tratado de 1858, interpretado por los ya mencionados laudos, a ejecutar trabajos para mejorar la navegación en el río San Juan cuando lo considere pertinente, y que estos trabajos incluyen el dragado del propio río San Juan; y,

iv. Al hacerlo, Nicaragua tiene derecho, cuando lo considere necesario, a reestablecer la situación existente al momento de la conclusión del Tratado de 1858;

v. Los únicos derechos de los que goza Costa Rica en el río San Juan de Nicaragua son aquellos definidos por dicho tratado bajo la interpretación de los laudos Cleveland y Alexander.

49. En los procedimientos orales en los casos conjuntos, las siguientes pretensiones fueron presentadas por las partes en el caso Costa Rica c. Nicaragua: 
En nombre del gobierno de Costa Rica, en la audiencia del 28 de abril de 2015:

Por las razones anteriormente expresadas en los procedimientos orales y escritos, la República de Costa Rica solicita a la Corte que:

1. Rechace todas las peticiones de Nicaragua;

2. Juzgue y declare que:

a) La soberanía sobre el territorio en disputa, definido por la Corte en sus órdenes del 8 de marzo de 2011 y del 22 de noviembre de 2013, pertenece a Costa Rica;

b) Al ocupar y reclamar territorio costarricense, Nicaragua ha violado:

i. La obligación de respetar la soberanía e integridad territorial de la República de Costa Rica, dentro de los límites establecidos por el Tratado de Límites de 1858 y definidos posteriormente por la Comisión de Demarcación establecida por el Acuerdo Pacheco-Matus, en particular por el primer y segundo laudo Alexander;

ii. La prohibición de la amenaza o uso de la fuerza bajo el artículo 2(4) de la Carta de las Naciones Unidas y el artículo 22 de la Carta de la Organización de los Estados Americanos;

iii. La prohibición de hacer el territorio de otros Estados, así sea temporalmente, objeto de ocupación militar, contraría al artículo 21 de la Carta de la Organización de los Estados Americanos; $y$

iv. La obligación de Nicaragua bajo el artículo IX del Tratado de Límites de 1858 de no usar el río San Juan para llevar a cabo actos hostiles.

c) Por su conducta subsecuente, Nicaragua ha violado:

i. La obligación de respetar el territorio y medio ambiente de Costa Rica, incluyendo su humedal de importancia internacional bajo la Convención de Ramsar, el "Humedal Caribe Noreste", en territorio costarricense;

ii. Los derechos perpetuos de libre navegación de Costa Rica en el río San Juan, según el Tratado de Límites de 1858, el laudo Cleveland de 1888 y la decisión de la Corte del 13 de julio de 2009; 
iii. La obligación de informar y consultar a Costa Rica acerca de cualquier dragado, desviación o alteración del curso del río San Juan, o cualquier otro trabajo en el río San Juan que pueda dañar el territorio costarricense (incluyendo el río Colorado), su medio ambiente o los derechos de Costa Rica, según el laudo Cleveland de 1888 y el derecho consuetudinario y convencional aplicable;

iv. La obligación de realizar un adecuado estudio de impacto ambiental transfronterizo que dé cuenta de todos los aspectos potencialmente adversos en territorio costarricense;

v. La obligación de no dragar, desviar o alterar el curso del río San Juan, o realizar cualquier otro trabajo en el río San Juan, si este causa daño ambiental al territorio de Costa Rica (incluyendo el río Colorado), su medio ambiente o a los derechos de Costa Rica según el laudo Cleveland de 1888;

vi. Las obligaciones contenidas en las órdenes de la Corte que indican medidas provisionales, del 8 de marzo de 2011 y el 22 de noviembre de 2013;

vii. La obligación de consultar a Costa Rica acerca de la implementación de las obligaciones que nacen de la Convención de Ramsar, en particular la obligación de coordinar políticas y regulaciones futuras concernientes a la conservación de humedales, su flora y fauna, bajo el artículo 5(1) de la Convención de Ramsar; y

viii. El acuerdo entre las partes, establecido por el canje de notas del 19 y 22 de noviembre de 2014, concerniente a la navegación en el río San Juan por Costa Rica cerca del caño oriental construido por Nicaragua en 2013.

d) Nicaragua no deberá proceder a ninguna operación de dragado u otro trabajo en tanto este pueda causar daño al territorio de Costa Rica (incluyendo el río San Juan) o su medio ambiente, o perjudique los derechos de Costa Rica bajo el laudo Cleveland de 1888, incluyendo su derecho a no ver su territorio ocupado sin su expreso consentimiento.

3. Que ordene, en consecuencia, que Nicaragua debe:

a) Repudiar, por los medios de su elección, lo previsto en el Decreto 079-2009 y las normas regulatorias anexas del $1^{\circ}$ de octubre de 2009, que son contrarias al derecho de Costa Rica a la libre navegación bajo el artículo VI del Tratado de 1858 y 
el laudo Cleveland de 1888, como a la decisión de la Corte del 13 de julio de 2009;

b) Cesar toda actividad de dragado en el río San Juan en la vecindad del Delta de Costa Rica y en el bajo río San Juan, aguardando:

i. Un apropiado estudio de impacto ambiental transfronterizo, que tenga en cuenta todos los potencialmente adversos impactos sobre territorio costarricense, desarrollado por Nicaragua y presentado a Costa Rica;

ii. Una notificación formal y escrita a Costa Rica sobre futuros planes de dragado en cercanías del Delta de Costa Rica y el bajo río San Juan, no menos de tres meses antes a la implementación de tales planes; $y$

iii. La debida consideración a cualquier comentario hecho por Costa Rica tras la recepción de tal notificación.

c) Reparar en forma de compensación por el daño material causado a Costa Rica, incluyendo pero no limitada a:

i. Daño producto de la construcción de caños artificiales y la destrucción de árboles y vegetación en el "territorio en disputa";

ii. Los costos de las medidas de mitigación realizadas por Costa Rica en relación con tales daños, incluyendo pero no limitados a aquellas tomadas en la cercanía del caño oriental construido por Nicaragua en 2013, en relación con el parágrafo 59(2)(e) de la orden sobre medidas provisionales de la Corte, del 22 de noviembre de 2013;

El monto de tales compensaciones deberá ser determinado en una fase separada de los procedimientos.

d) Proveer satisfacción para lograr la plena reparación de los perjuicios causados a Costa Rica, en la manera que la Corte determine;

e) Proveer garantías adecuadas de no repetición frente a la conducta ilegal de Nicaragua, en la forma que la Corte ordene; y

f) Pagar todos los costos y gastos incurridos por Costa Rica en la solicitud y obtención de la orden de medidas provisionales del 22 de noviembre de 2013, incluyendo, pero no limitadas a, las tarifas y gastos de los abogados y expertos de Costa Rica, incluyendo intereses, bajo una plena compensación. 


\section{En nombre del gobierno de Nicaragua, en audiencia del miércoles 29 de abril de 2015:}

Según el artículo 60 del Reglamento y las razones dadas durante las fases escritas y orales, la República de Nicaragua respetuosamente solicita a la Corte que:

a) Desestime y rechace las pretensiones y solicitudes de Costa Rica;

b) Juzgue y declare que:

i. Nicaragua tiene soberanía plena sobre el caño que une la laguna de Harbor Head con el río San Juan, del cual el banco derecho constituye la frontera terrestre establecida por el Tratado de 1858 e interpretada por los laudos Cleveland y Alexander;

ii. Que Costa Rica se encuentra en la obligación de respetar la soberanía e integridad territorial de Nicaragua, dentro de los límites establecidos por el Tratado de 1858 e interpretados por los laudos Cleveland y Alexander;

iii. Nicaragua tiene derecho, según el Tratado de 1858 y la interpretación de los subsecuentes laudos arbitrales, a ejecutar trabajos para mejorar la navegación del río San Juan como lo considere pertinente, y que esos trabajos incluyen el dragado del río San Juan de Nicaragua;

iv. Que los únicos derechos de Costa Rica en el río San Juan son los definidos por dicho tratado, interpretado por el laudo Cleveland y los laudos Alexander.

50. En su demanda presentada en el caso Nicaragua c. Costa Rica, Nicaragua hizo las siguientes pretensiones:

Basada en las anteriores afirmaciones de hecho y de derecho, Nicaragua, reservándose el derecho de complementar, enmendar o modificar su demanda, solicita a la Corte que juzgue y declare que Costa Rica ha violado:

a) Su obligación de no violar la integridad territorial de Nicaragua según su delimitación por el Tratado de Límites de 1858, el laudo Cleveland de 1888 y los cinco laudos del árbitro E. P. Alexander del 
30 de septiembre de 1897, 20 de diciembre de 1897, 22 de marzo de 1898, 26 de julio de 1899 y 10 de marzo de 1900;

b) Su obligación de no dañar el territorio nicaragüense;

c) Sus obligaciones bajo el derecho internacional general y las convenciones de derecho ambiental relevantes, incluyendo la Convención de Ramsar, el Acuerdo sobre Áreas Fronterizas Protegidas entre Nicaragua y Costa Rica (sistema internacional de áreas protegidas para la paz, Acuerdo SI-A—PAZ), y el Convenio para la Conservación de la Biodiversidad y Protección de Áreas Silvestres Prioritarias en América Central.

Adicionalmente, Nicaragua le solicita a la Corte que juzgue y declare que Costa Rica debe:

a) Restaurar la situación a su status quo ante;

b) Pagar todos los daños causados, incluyendo los costos adicionados al dragado del río San Juan;

c) No perseverar en ningún otro proyecto en el área sin un adecuado estudio de impacto ambiental transfronterizo, y que tal estudio sea presentado en debido tiempo y forma a Nicaragua para su análisis y reacción.

Finalmente, Nicaragua solicita a la Corte que juzgue y declare que Costa Rica debe:

a) Cesar toda construcción actual que afecte o pueda afectar los derechos de Nicaragua;

b) Producir y presentar a Nicaragua un estudio de impacto ambiental adecuado con todos los detalles de la obra.

51. En el desarrollo de los procedimientos escritos en el caso Nicaraguac. Costa Rica, las siguientes solicitudes fueron presentadas por las partes:

En nombre del gobierno de Nicaragua, en el memorial:

1. Por las razones dadas anteriormente, la República de Nicaragua solicita a la Corte que juzgue y declare que, con su conducta, Costa Rica ha violado: 
i. Su obligación de no violar la integridad territorial de Nicaragua según su delimitación por el Tratado de Límites de 1858, el laudo Cleveland de 1888 y los cinco laudos del árbitro E. P. Alexander del 30 de septiembre de 1897, 20 de diciembre de 1897, 22 de marzo de 1898, 26 de julio de 1899 y 10 de marzo de 1900;

ii. Su obligación de no dañar el territorio nicaragüense;

iii. Sus obligaciones bajo el derecho internacional general y las convenciones de derecho ambiental relevantes, incluyendo la Convención de Ramsar, el Acuerdo sobre Áreas Fronterizas Protegidas entre Nicaragua y Costa Rica (sistema internacional de áreas protegidas para la paz, Acuerdo SI-A-PAZ), y el Convenio para la Conservación de la Biodiversidad y Protección de Áreas Silvestres Prioritarias en América Central.

2. Adicionalmente, Nicaragua solicita a la Corte que juzgue y declare que Costa Rica:

i. Cese toda construcción actual que afecte o pueda afectar los derechos de Nicaragua;

ii. Restaurar la situación a su status quo ante;

iii. Pagar todos los daños causados, incluyendo los costos adicionados al dragado del río San Juan, siendo el monto de la compensación decidido en una fase subsecuente del caso;

iv. No perseverar en ningún otro proyecto en el área sin un adecuado estudio de impacto ambiental transfronterizo, y que tal estudio sea presentado en debido tiempo y forma a Nicaragua para su análisis y reacción.

3. La República de Nicaragua, consecuentemente, solicita a la Corte que juzgue y declare que:

i. Nicaragua tiene derecho, según el Tratado de 1858 y la interpretación de los subsecuentes laudos arbitrales, a ejecutar trabajos para mejorar la navegación del río San Juan como lo considere pertinente, y que esos trabajos incluyen el dragado del río San Juan de Nicaragua para remover sedimentación y otras barreras a la navegación; $y$,

ii. Al hacerlo, Nicaragua tiene derecho a restablecer las condiciones de navegación existentes para el momento en que el Tratado de 1858 fue concluido;

iii. Que las violaciones al Tratado de 1858 y otras reglas de derecho internacional de Costa Rica le permiten a Nicaragua la toma 
de contramedidas apropiadas, incluyendo la suspensión de los derechos de navegación de Costa Rica en el río San Juan de Nicaragua.

4. Finalmente, Nicaragua solicita a la Corte que le ordene a Costa Rica que de forma inmediata tome las medidas de emergencia recomendadas por sus propios expertos y detalladas en el Reporte Kondolf, para aliviar o mitigar el continuado daño que se está causando al río San Juan de Nicaragua y su ambiente colindante.

En la réplica:

Por las razones dadas en su memorial y en esta réplica, la República de Nicaragua solicita a la Corte que juzgue y declare que, con su conducta, la República de Costa Rica ha violado:

i. Su obligación de no violar la integridad territorial de Nicaragua según su delimitación por el Tratado de Límites de 1858, el laudo Cleveland de 1888 y los cinco laudos del árbitro E. P. Alexander del 30 de septiembre de 1897, 20 de diciembre de 1897, 22 de marzo de 1898, 26 de julio de 1899 y 10 de marzo de 1900;

ii. Su obligación de no dañar el territorio nicaragüense;

iii. Sus obligaciones bajo el derecho internacional general y las convenciones de derecho ambiental relevantes, incluyendo la Convención de Ramsar, el Acuerdo sobre Áreas Fronterizas Protegidas entre Nicaragua y Costa Rica (sistema internacional de áreas protegidas para la paz, Acuerdo SI-A-PAZ), y el Convenio para la Conservación de la Biodiversidad y Protección de Áreas Silvestres Prioritarias en América Central.

2. Nicaragua también le solicita a la Corte que juzgue y declare que Costa Rica debe:

i. Cesar en todos sus actos internacionalmente ilícitos que afectan o puedan afectar los derechos de Nicaragua;

ii. En tanto sea posible, restaurar la situación a su status quo ante, en pleno respeto de la soberanía territorial de Nicaragua sobre el río San Juan de Nicaragua, incluyendo la toma de medidas de emergencia para aliviar o mitigar el daño que se está causando al río San Juan de Nicaragua y su ambiente colindante; 
iii. Pagar todos los daños causados, en tanto no sean cubiertos por la restitución, incluyendo los costos adicionados al dragado del río San Juan, siendo el monto de la compensación decidido en una fase subsecuente del caso.

3. Adicionalmente, Nicaragua le solicita a la Corte que juzgue y declare que Costa Rica debe:

i. No perseverar en ningún otro proyecto en el área sin un adecuado estudio de impacto ambiental transfronterizo, y que tal estudio sea presentado en debido tiempo y forma a Nicaragua para su análisis y reacción;

ii. Abstenerse de usar la ruta 1856 para transportar material peligroso en tanto no ha dado garantías de que la ruta cumple con las mejores prácticas de construcción y los más altos estándares regionales e internacionales de seguridad para el tráfico vial en condiciones similares.

4. La República de Nicaragua adicionalmente le solicita a la Corte que juzgue y declare que tiene derecho:

i. Según el Tratado de 1858 y la interpretación de los subsecuentes laudos arbitrales, a ejecutar trabajos para mejorar la navegación del río San Juan como lo considere pertinente, y que esos trabajos incluyen el dragado del río San Juan de Nicaragua para remover sedimentación y otras barreras a la navegación; y,

ii. Al hacerlo, Nicaragua tiene derecho a restablecer las condiciones de navegación existentes para el momento en que el Tratado de 1858 fue concluido.

5. Finalmente, si la Corte no ha elegido un experto neutral al momento de adoptar su decisión, Nicaragua le solicita a la Corte que seleccione tal experto, quien puede aconsejar a las partes en la implementación de la sentencia.

En nombre del gobierno de Costa Rica, en la contramemoria:

"Por tales razones, y reservándose el derecho a adicionar, amplificar o enmendar la presente, Costa Rica solicita a la Corte que desestime todas las pretensiones de Nicaragua en este procedimiento".

En la dúplica: 
"Por tales razones, y reservándose el derecho a adicionar, amplificar o enmendar la presente, Costa Rica solicita a la Corte que desestime todas las pretensiones de Nicaragua en este procedimiento".

52. Durante los procedimientos orales en los casos conjuntos, las siguientes pretensiones fueron presentadas por las partes en el caso $\mathrm{Ni}$ caragua c. Costa Rica:

En nombre del gobierno de Nicaragua,

en la audiencia del 30 de abril de 2015 :

1. De acuerdo con el artículo 60 del Reglamento y las razones dadas durante la fase escrita y oral, la República de Nicaragua respetuosamente solicita a la Corte que juzgue y declare que, con su conducta, la República de Costa Rica ha violado:

i. Su obligación de no violar la integridad territorial de Nicaragua según su delimitación por el Tratado de Límites de 1858, el laudo Cleveland de 1888 y los cinco laudos del árbitro E. P. Alexander del 30 de septiembre de 1897, 20 de diciembre de 1897, 22 de marzo de 1898, 26 de julio de 1899 y 10 de marzo de 1900;

ii. Su obligación de no dañar el territorio de Nicaragua;

iii. Sus obligaciones bajo el derecho internacional general y las convenciones de derecho ambiental relevantes, incluyendo la Convención de Ramsar, el Acuerdo sobre Áreas Fronterizas Protegidas entre Nicaragua y Costa Rica (sistema internacional de áreas protegidas para la paz, Acuerdo SI-A-PAZ), y el Convenio para la Conservación de la Biodiversidad y Protección de Áreas Silvestres Prioritarias en América Central.

2. Nicaragua también le solicita a la Corte que juzgue y declare que Costa Rica debe:

i. Cesar en todos sus actos internacionalmente ilícitos que afectan o puedan afectar los derechos de Nicaragua;

ii. En tanto sea posible, restaurar la situación a su status quo ante, en pleno respeto de la soberanía territorial de Nicaragua sobre el río San Juan de Nicaragua, incluyendo la toma de medidas de emergencia para aliviar o mitigar el daño que se está causando al río San Juan de Nicaragua y su ambiente colindante;

iii. Pagar todos los daños causados, en tanto no sean cubiertos por la restitución, incluyendo los costos adicionados al dragado del 
río San Juan, siendo el monto de la compensación decidido en una fase subsecuente del caso.

3. Adicionalmente, Nicaragua solicita a la Corte que juzgue y declare que Costa Rica debe:

i. No perseverar en ningún otro proyecto en el área sin un adecuado estudio de impacto ambiental transfronterizo, y que tal estudio sea presentado en debido tiempo y forma a Nicaragua para su análisis y reacción;

ii. Abstenerse de usar la ruta 1856 para transportar material peligroso en tanto no ha dado garantías de que la ruta cumple con las mejores prácticas de construcción y los más altos estándares regionales e internacionales de seguridad para el tráfico vial en condiciones similares.

4. La República de Nicaragua consecuentemente solicita a la Corte que juzgue y declare que Nicaragua tiene derecho:

i. Según el Tratado de 1858 y la interpretación de los subsecuentes laudos arbitrales, a ejecutar trabajos para mejorar la navegación del río San Juan como lo considere pertinente, y que esos trabajos incluyen el dragado del río San Juan de Nicaragua para remover sedimentación y otras barreras a la navegación.

\section{En nombre del gobierno de Costa Rica,}

en audiencia del 1 de mayo de 2015:

"Por las razones expresadas en los procedimientos escritos y orales, Costa Rica solicita que la Corte desestime todas las pretensiones de Nicaragua en el presente procedimiento".

53. La Corte iniciará abordando los elementos que son comunes a ambos casos. Abordará, en primer lugar, el asunto de su jurisdicción, antes de referirse, en una segunda parte, al contexto geográfico e histórico, como al origen de las disputas.

La Corte luego examinará a su turno, en dos secciones separadas, los asuntos en disputa en los casos Costa Rica c. Nicaragua y Nicaragua c. Costa Rica. 


\section{Jurisdicción de la Corte}

54. En relación con el caso Costa Rica c. Nicaragua, la Corte reconoce que Costa Rica invoca, como base de jurisdicción, el artículo XXXI del Pacto de Bogotá y las declaraciones por medio de las cuales las partes han reconocido la jurisdicción obligatoria bajo los parágrafos 2 y 5 del artículo 36 del Estatuto (ver parágrafo 2). También hace notar que Nicaragua no ha objetado esta jurisdicción para responder a la demanda de Costa Rica.

La Corte encuentra que tiene jurisdicción sobre la disputa.

55. En relación con el caso Nicaragua c. Costa Rica, la Corte reconoce que Nicaragua invoca, como base de jurisdicción, el artículo XXXI del Pacto de Bogotá y las declaraciones previamente mencionadas (ver parágrafo 2). También hace notar que Costa Rica no ha objetado esta jurisdicción para responder a la demanda de Nicaragua.

La Corte encuentra que tiene jurisdicción sobre la disputa.

\section{Contexto histórico y geográfico y origen de las disputas}

56. El río San Juan se extiende por aproximadamente 205 kilómetros desde el lago Nicaragua hasta el mar Caribe. En un punto conocido como el Delta del Colorado (o Delta de Costa Rica), el río San Juan se divide en dos ramas: el bajo río San Juan es la rama más al norte de aquellas, y fluye hasta donde se vierte en el mar Caribe, $30 \mathrm{~km}$ corriente abajo del delta, cerca del pueblo de San Juan de Nicaragua, antes conocido como San Juan del Norte o Greytown; el río Colorado es la más prolongada de estas dos ramas, ubicado al sur, y fluye enteramente en Costa Rica, alcanzando el mar Caribe en Barra del Colorado, unos $20 \mathrm{~km}$ al sur este de la desembocadura del bajo río San Juan. Las partes concuerdan en que el río Colorado actualmente recibe aproximadamente el 90\% del agua del río San Juan, el restante $10 \%$ fluye hacia el bajo río San Juan.

57. El área situada entre el río Colorado y el bajo río San Juan es generalmente conocida como Isla Calero (aproximadamente 150 kilómetros cuadrados). Dentro de esta área, existe una pequeña región conocida en Costa Rica como Isla Portillos y, para Nicaragua, como Harbor Head (aproximadamente 17 kilómetros cuadrados). Se encuentra al norte de lo 
que era el río Taura. Al norte de Isla Portillos se encuentra una laguna, conocida como laguna Los Portillos en Costa Rica y como laguna de Harbor Head en Nicaragua. Esta laguna se encuentra separada actualmente del mar Caribe por un banco de arena (ver mapa 1).

58. La Isla Calero es parte del Humedal Caribe Noreste, que fue designado en 1996 por Costa Rica como humedal de importancia internacional bajo la Convención de Ramsar. El área inmediatamente adyacente -incluyendo el río San Juan y una franja de tierra de 2 kilómetros de ancho colindante al banco izquierdo (nicaragüense) — fue designada por Nicaragua como humedal de importancia internacional bajo la Convención de Ramsar en 2001 y es conocido como el Refugio de Vida Silvestre Río San Juan.

59. Las presentes disputas entre las partes se dan dentro de un contexto histórico que data de los años 1850. Tras hostilidades entre los dos Estados en 1857, los gobiernos de Costa Rica y Nicaragua firmaron el 15 de abril de 1858 un Tratado de Límites, que fue ratificado por Costa Rica el 16 de abril de 1858 y por Nicaragua el 26 de abril de 1858 (en adelante el Tratado de 1858). El Tratado de 1858 fijaba el curso del límite entre Costa Rica y Nicaragua del océano Pacífico al mar Caribe. Según el artículo II del Tratado (transcrito en el parágrafo 71), parte de la frontera entre los dos Estados pasa por el banco derecho (costarricense) del río San Juan desde un punto a tres millas inglesas bajo Castillo Viejo, una pequeña población de Nicaragua, a "el fin de Punta de Castilla, en la desembocadura del río San Juan" en la costa del mar Caribe. El artículo VI del Tratado de 1858 (parágrafo 133 más adelante) establece que Nicaragua tiene dominium e imperium sobre las aguas del río, pero a la vez afirma los derechos de libre navegación de Costa Rica en el río, con propósitos comerciales. 


\section{3}

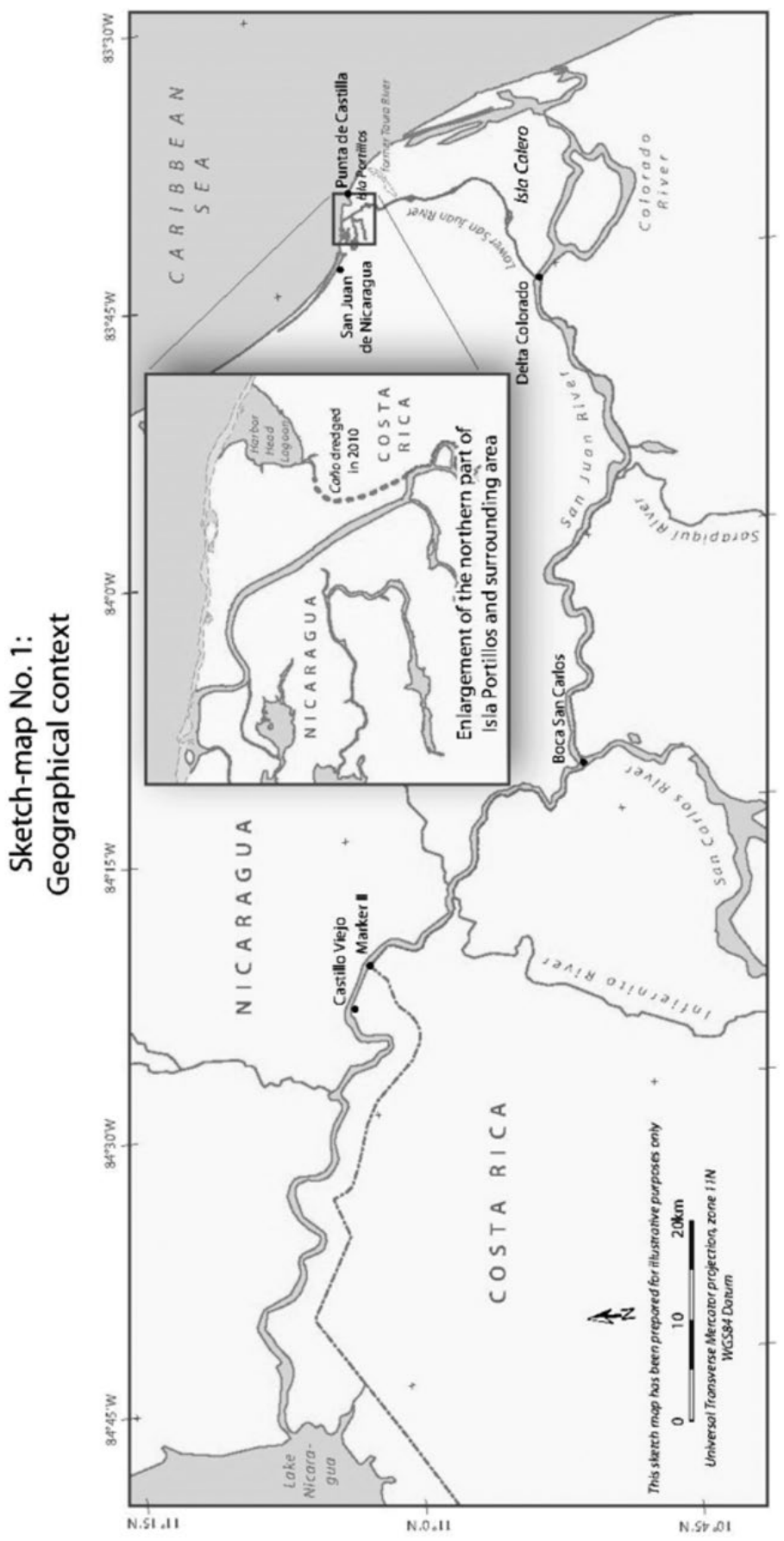



点

$\stackrel{0}{=}$

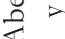

ACDI, Bogotá, ISSN: 2027-1131/ISSNe: 2145-4493, Vol. 10, pp. 427-543, 2017 
60. Tras numerosos cuestionamientos de Nicaragua sobre la validez del Tratado de 1858, Costa Rica y Nicaragua firmaron otro instrumento el 24 de diciembre de 1886, donde los dos Estados acordaban someter la cuestión de la validez del Tratado de 1858 a arbitraje del Presidente de los Estados Unidos, Grover Cleveland. Adicionalmente, las partes acordaron que, si el Tratado de 1858 era encontrado válido, el presidente Cleveland debería también decidir sobre "todo otro punto de dudosa interpretación que cualquiera de las partes encontrará en el Tratado". El 22 de junio de 1887, Nicaragua comunicó a Costa Rica 11 puntos de dudosa interpretación, que subsecuentemente se transmitieron al presidente Cleveland para su resolución. El laudo Cleveland de 1888 confirma, en su parágrafo 1, la validez del Tratado de 1858 y encuentra, en su parágrafo (3)(1), que la línea divisoria entre los dos Estados en el lado atlántico "inicia en el extremo de Punta de Castilla en la desembocadura del río San Juan de Nicaragua, como ambos existían el 15 de abril de 1858". El laudo Cleveland también resolvió los otros puntos de dudosa interpretación presentados por Nicaragua, como las condiciones bajo las cuales Nicaragua podía realizar trabajos de mejora del río San Juan — parágrafo 3(6), citado en el parágrafo 116 adelante-, las condiciones bajo las cuales Costa Rica puede prevenir que Nicaragua desvíe las aguas del San Juan — parágrafo 3(9) citado en el parágrafo 116 adelante- y el requisito de que Nicaragua no tome garantías con el propósito de construir un canal en su territorio sin antes consultar la opinión de Costa Rica — parágrafo 3(10)—o, "cuando la construcción del canal implique algún daño a los derechos naturales de Costa Rica", obteniendo su consentimiento — parágrafo 3(11)—.

61. Tras el laudo Cleveland, Costa Rica y Nicaragua acordaron en 1896, bajo el Convenio Pacheco-Matus de demarcación fronteriza, establecer dos Comisiones de Demarcación Nacional, cada una compuesta por dos miembros (art. I). El Convenio Pacheco-Matus posteriormente prescribiría que las comisiones deberían incluir un ingeniero, nombrado por el Presidente de los Estados Unidos de América, quien "tendría amplios poderes para decidir cualquiera de las diferencias que surgieran en el curso de cualquier operación y sus decisiones serían finales" (art. II). El general de los Estados Unidos Edward Porter Alexander fue nombrado como tal. Durante el proceso de demarcación, que inició en 1897 y fue concluido en 1900, el general Alexander produjo cinco laudos, los primeros tres de relevancia particular para el caso Costa Rica c. Nicaragua (ver parágrafos 73-75 adelante). 
62. Iniciando en 1980, algunos desacuerdos surgieron entre Costa Rica y Nicaragua, concernientes al alcance preciso de los derechos de navegación de Costa Rica bajo el Tratado de 1858. Esta disputa llevó a Costa Rica a presentar una demanda ante la Corte, dando inicio a los procedimientos contra Nicaragua el 29 de septiembre de 2005. La Corte dictó su fallo el 13 de julio de 2009, donde, inter alia, clarificó los derechos de navegación de Costa Rica y el alcance del poder de Nicaragua de regular la navegación en el río San Juan - Asunto relativo a los derechos de navegación y derechos conexos (Costa Rica c. Nicaragua), sentencia de fondo, CIJ Reportes 2009, p. 213-.

63. El 18 de octubre de 2010, Nicaragua inició el dragado del río San Juan para mejorar su navegabilidad. También desarrolló trabajos en la parte norte de Isla Portillos (ver mapa 1). En este respecto, Costa Rica sostiene que Nicaragua artificialmente creó un canal (ambas partes se refieren a estos canales como caños) en territorio costarricense, en Isla Portillos entre el río San Juan y la laguna Los Portillos/laguna de Harbor Head, mientras que Nicaragua argumenta que solo despejaba un caño existente en territorio nicaragüense. Nicaragua también envió algunas unidades militares y otro personal al área. El 18 de noviembre de 2010, Costa Rica presentó su demanda, iniciando procedimientos en el caso Costa Rica c. Nicaragua (ver parágrafo 1). Costa Rica también presentó una petición solicitando la toma de medidas provisionales bajo el artículo 41 del Estatuto (ver parágrafo 3).

64. En diciembre de 2010, Costa Rica inició trabajos para la construcción de la ruta 1856 Juan Rafael Mora Porras (en adelante la ruta/ la carretera), que va por el territorio costarricense y parte de su frontera con Nicaragua. La ruta tiene una longitud planeada de 159,7 kilómetros, extendiéndose desde Los Chiles en el occidente hasta un punto más allá del Delta del Colorado al este. Por 108,2 kilómetros, sigue el curso del río San Juan (ver mapa 2). El 21 de febrero de 2011, Costa Rica adoptó un decreto ejecutivo en el que declaraba el Estado de emergencia en el área de frontera, que Costa Rica sostiene le eximía de la obligación de realizar un estudio de impacto ambiental antes de construir la ruta. El 22 de diciembre de 2011, Nicaragua presentó su demanda, iniciando procedimientos en el caso Nicaragua c. Costa Rica (ver parágrafo 9), sosteniendo en particular que la construcción de la ruta derivó en daño transfronterizo significativo. 


\section{6}

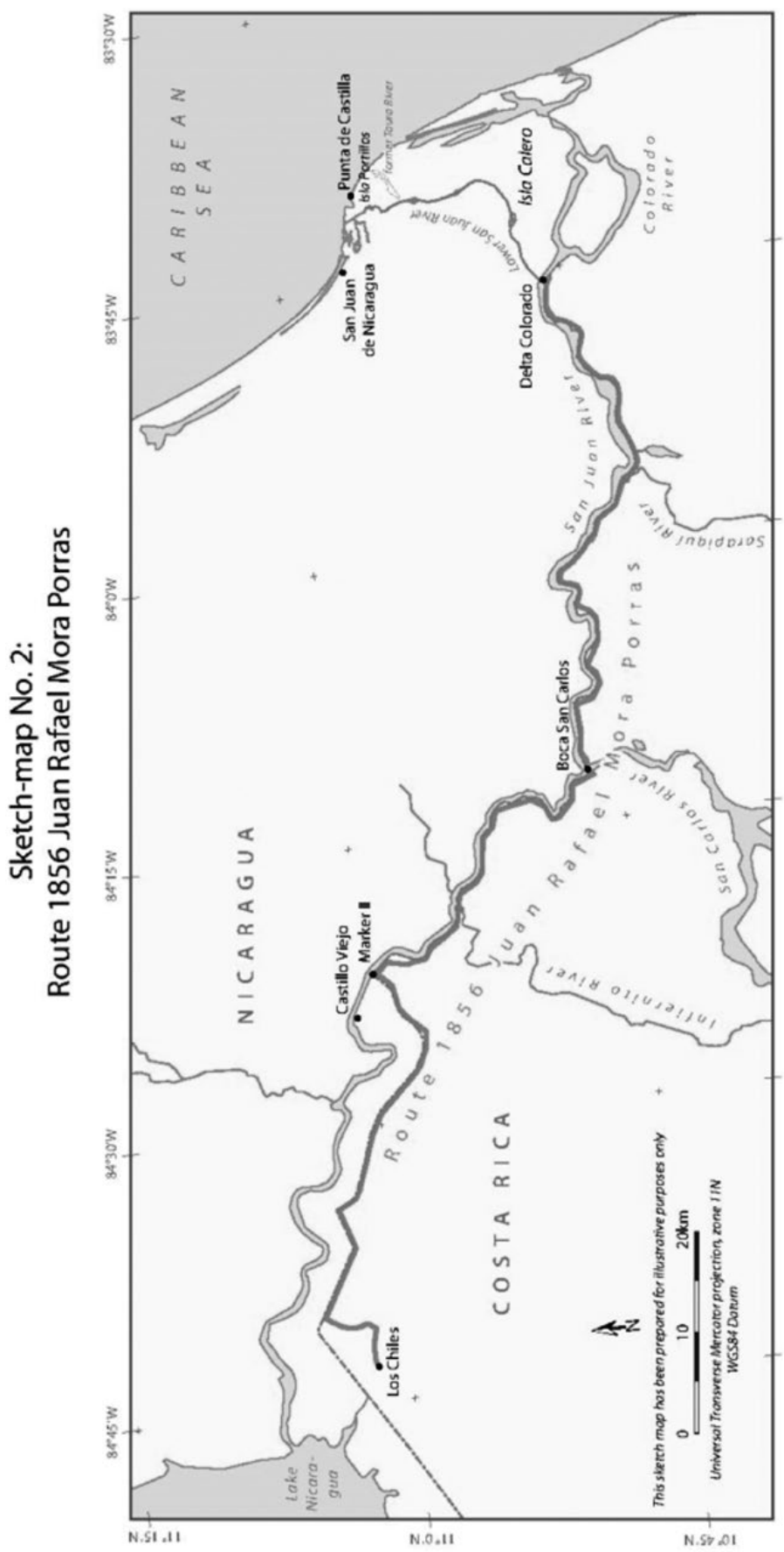




\section{Asuntos en el caso Costa Rica c. Nicaragua}

\section{A. Soberanía sobre el territorio en disputa y presuntas violaciones conexas}

65. Costa Rica sostiene que Nicaragua violó "la obligación de respetar la soberanía e integridad territorial de la República de Costa Rica, dentro de las fronteras delimitadas por el Tratado de Límites de 1858 y posteriormente demarcadas por la Comisión de Demarcación establecida por el Acuerdo Pacheco-Matus, en particular por el primer y segundo laudo Alexander" — solicitudes finales, para. 2(b)(i)—. Esta pretensión se basa en la premisa de que "la soberanía sobre el territorio en disputa, como lo definió la Corte en sus órdenes del 8 de marzo de 2011 y 22 de noviembre de 2013, pertenece a la República de Costa Rica" —ibíd., para. 2(a)—. En sus solicitudes finales, Costa Rica pide a la Corte que se pronuncie sobre la soberanía del territorio en disputa.

66. Costa Rica alega que Nicaragua violó su integridad territorial en el área de Isla Portillos, particularmente al excavar en 2010 un caño con el fin de conectar el río San Juan con la laguna de Harbor Head, y reclamar territorio costarricense. Según Costa Rica, esta violación de su soberanía se ve exacerbada por el establecimiento de presencia militar de Nicaragua en el área y por su excavación, en 2013, de otros dos caños localizados cerca de la punta norte de la Isla Portillos.

67. La Corte nota que, aunque las violaciones que presuntamente tuvieron lugar en 2013 ocurrieron después de la demanda, corresponden a hechos de la misma naturaleza a aquellos contemplados en la demanda y sobre los cuales las partes tuvieron la oportunidad de discutir durante los alegatos. Estas presuntas violaciones pueden ser, por lo tanto, examinadas por la Corte como parte de los méritos de la demanda. Ellas serán también posteriormente consideradas en relación con el cumplimiento de Nicaragua de la orden de medidas provisionales del 8 de marzo de 2011.

68. Nicaragua no niega que hubiese dragado los tres caños, pero sostiene que "Nicaragua goza de plena soberanía sobre el caño que une la laguna de Harbor Head con el propio río San Juan, cuyo banco derecho constituye la frontera terrestre según lo establecido en el Tratado de 1858 de acuerdo con la interpretación de los laudos Cleveland y Alexander" — solicitudes finales, para. (b)(i)—. Nicaragua posteriormente sostiene que "Costa Rica está en la obligación de respetar la soberanía e integridad territorial de Nicaragua, dentro de los límites establecidos por el Tratado 
de 1858 y su interpretación por los laudos Cleveland y Alexander" —ibíd., para. (b) (ii)—.

69. En tanto es inobjetado que Nicaragua condujera ciertas actividades en el territorio disputado, es necesario, en orden de establecer si existió una violación a la soberanía territorial de Costa Rica, determinar cuál Estado tiene soberanía sobre ese territorio. El "territorio en disputa" fue definido por la Corte en su orden del 8 de marzo sobre medidas provisionales como "la parte más al norte de la Isla Portillos, que es el área de humedal de aproximadamente 3 kilómetros cuadrados entre el banco derecho del caño en disputa, el banco derecho del río San Juan, hasta la desembocadura de este en el mar Caribe y la laguna de Harbor Head — ICJ Reports 2011, (I), p. 19, para. 55-. El caño referido es el que fue dragado por Nicaragua en 2010. Nicaragua no objeta esta definición del territorio en disputa, mientras que Costa Rica expresamente la compartió en sus solicitudes finales — para. 2(a)—. La Corte mantendrá la definición de "territorio disputado" dada en su orden de 2011. Recuerda también que en su orden del 22 de noviembre de 2013, indicando medidas provisionales, especificó que un campamento militar "localizado en la playa y cerca de la línea de vegetación" cerca de uno de los caños dragados en 2013 estaba "situado en el territorio en disputa según la definición de la orden del 8 de marzo de 2011" (ICJ Reports 2013, p. 365, para. 46).

70. La definición anterior del territorio en disputa no se refiere de forma específica a la extensión de la costa Caribe que se encuentra entre la laguna de Harbor Head, que ambas partes concuerdan es nicaragüense, y la desembocadura del río San Juan. En los argumentos orales, las partes expresaron diferentes posiciones al respecto. En todo caso, no se refirieron al asunto de la ubicación precisa de la desembocadura del río ni entregaron información detallada concerniente a la costa. Ninguna de las partes solicitó a la Corte definir el límite de manera más precisa en relación con esta costa, por lo que la Corte se abstendrá de ello.

71. En sus pretensiones sobre el territorio en disputa, ambas partes se refirieron al Tratado de 1858, el laudo Cleveland y los laudos Alexander. Según el artículo II del Tratado:

"La línea divisoria de las dos repúblicas, partiendo del mar del Norte, comenzará en la extremidad de Punta de Castilla, en la desembocadura del río San Juan de Nicaragua, y continuará marcándose con la margen derecha del expresado río, hasta un punto distante del Castillo Viejo tres millas inglesas..." (original del español). 
72. En 1888, el presidente Cleveland encontró en su laudo que:

"la línea divisoria entre las repúblicas de Costa Rica y Nicaragua, en el lado Atlántico, comienza en la extremidad de Punta de Castilla en la desembocadura del río San Juan de Nicaragua, como ambos existían para el día 15 del mes de abril de 1858. La propiedad de cualquier acrecimiento a dicha Punta de Castilla se gobierna por las normas aplicables a tal asunto" -Naciones Unidas, Reportes de laudos arbitrales internacionales (RIAA, Vol. XXVIII, p. 209-.

73. Cuando las Comisiones de Demarcación fueron establecidas por el Acuerdo Pacheco-Matus, uno de sus miembros, que era designado por el Presidente de los Estados Unidos de América, debía tener el poder de "resolver cualquier disputa entre las comisiones de Costa Rica y Nicaragua resultantes de su operación" (ver parágrafo 61). Según este acuerdo, "dicha persona deberá tener poderes amplios para decidir cualquier tipo de diferencias que puedan surgir en el curso de la operación y su decisión debe ser final" (art. II, RIAA, Vol. XXVIII, p. 212). Bajo tal precepto, el general Alexander, quien había sido asignado para tal posición, produjo cinco laudos concernientes a la frontera. En su primer laudo, indicó que la línea divisoria:

"debe seguir... la rama... llamada bajo río San Juan, por su costa y hasta el mar. El fin natural de tal línea es el cabo de la mano derecha de la desembocadura".

Él observó que:

"a lo largo del Tratado el río es tratado y reconocido como un medio del comercio. Esto implica que debe considerársele como en una situación promedio del agua, en cuya condición sea navegable" (ibíd., pp. 218-219).

Seguidamente, define la parte inicial del límite iniciando en el mar Caribe, en los siguientes términos:

El lugar exacto que fue la extremidad del cabo de Punta Castillo el 15 de abril de 1858 ha sido hace tiempo barrido por el mar Caribe y existe poca concurrencia entre la línea costera de los viejos mapas que permita afirmar con alguna certeza algo sobre la proyección exacta de ella frente al cabo presente. Se encontraba en algún punto al noreste, probablemente entre 600 y 1.600 pies de distancias, pero no puede ser localizada exactamente hoy. Bajo tales circunstancias, sirve mejor a los fines del Tratado y a los laudos del presidente Cleveland, adoptar lo que es hoy prácticamente el cabo actual, o la extremidad noroccidental de lo que parece ser tierra firme, en el lado este de la laguna de Harbor Head. 
He hecho una inspección personal de este terreno y declaro que la línea inicial del límite se proyecta de la siguiente manera:

Su dirección debe ser noreste a suroeste, cruzando el banco de área, del mar Caribe hacia las aguas de la laguna de Harbor Head. Debe pasar, en su punto más cercano, a 300 pies del lado noroccidental de la pequeña cabaña que actualmente se encuentra en tal vecindad. Al llegar a las aguas de la laguna de Harbor Head, la línea divisoria debe girar a la izquierda, o al sureste, y debe seguir el borde del agua alrededor del cabo hasta llegar al propio río por el primero de los canales. En este canal y río arriba, la línea debe continuar ascendiendo según el Tratado" (ibíd., p. 220).

Un diagrama que ilustra la parte inicial del límite en la situación geográfica de la época fue anexado a este primer laudo (ibíd., p. 221). En tal diagrama, lo que el árbitro consideró como el "primer canal" fue la rama del bajo río San Juan que fluía hacia la laguna de Harbor Head (ver mapa 3). La misma línea divisoria fue diagramada con mayor precisión en los procedimientos de las Comisiones de Demarcación.

Sketch-map No. 3: Printed sketch-map attached to Alexander's First Award

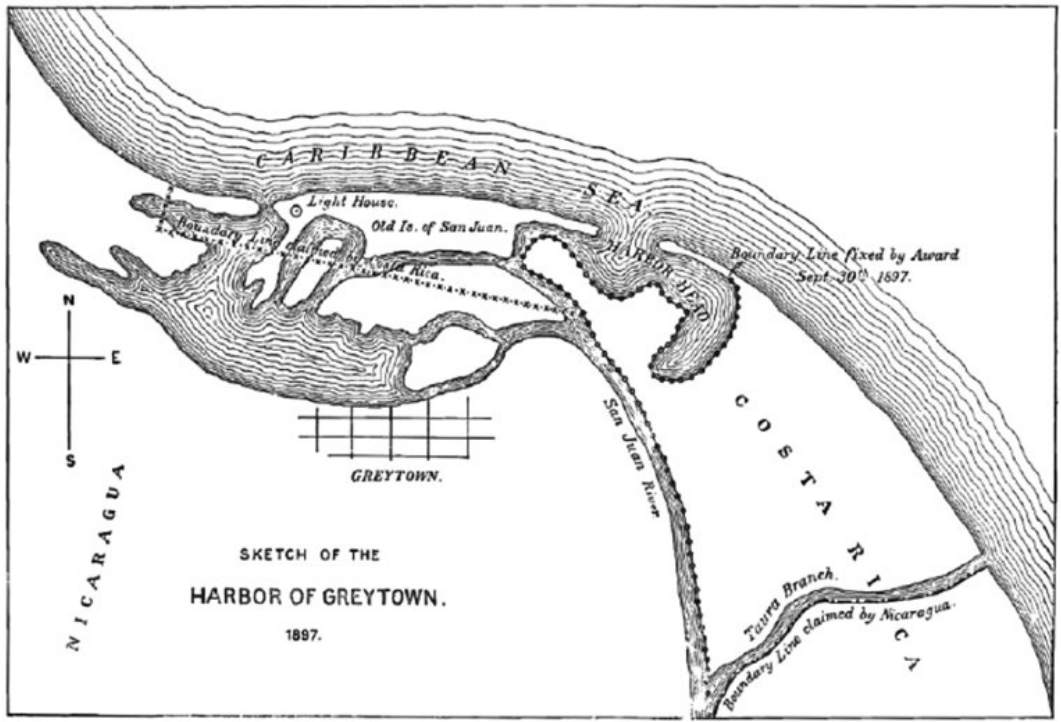


74. El segundo laudo Alexander contempló la posibilidad de que los bancos del río San Juan pudieran "no solo gradualmente expandirse y contraerse, sino que hubiera cambios radicales en ellos". El árbitro observó que:

"la línea actual debe necesariamente verse afectada en el futuro por todos esos cambios graduales o súbitos. Pero su impacto en cada caso solo puede ser determinado por las circunstancias del caso, en un proceder caso a caso, en concordancia con los principios de derecho internacional aplicables.

La medición y demarcación propuesta del límite no tendrá ningún efecto en la aplicación de tales principios" (RIAA, Vol. XXVIII, p. 224).

75. En su tercer laudo, el general Alexander notó que "las fronteras delimitadas por cursos de agua son susceptibles a cambiar cuando ocurren variaciones en el lecho de tales cursos. En otras palabras, es el lecho del río el que implica cambios y no las aguas sobre él, sobre o en sus bancos" (ibíd., p. 229). Él llegó a la siguiente conclusión:

Permítanme concluir brevemente y entregar un entendimiento más claro de todo el asunto relativo a los principios desarrollados anteriormente en mi primer laudo, es decir, que, en la interpretación práctica del Tratado de 1858, el río San Juan debe ser considerado un río navegable. Por lo tanto, declaro que la línea exacta que divide las jurisdicciones de los dos países es el banco derecho del río, con el agua a un nivel normal navegable por barcos y naves de propósitos generales. En el momento, toda porción de las aguas del río se encuentra en jurisdicción de Nicaragua. Toda porción del banco derecho se encuentra en jurisdicción de Costa Rica (ibíd., p. 230).

76. La Corte considera que el Tratado de 1858 y los laudos del presidente Cleveland y del general Alexander llevan a la conclusión de que el artículo II del Tratado de 1858, que ubica el límite en el "banco derecho... del río" debe ser interpretado en el contexto del artículo VI (citado completamente en el parágrafo 133), que indica que "la República de Costa Rica debe... tener un derecho perpetuo de libre navegación en... las aguas (del río) entre su desembocadura... y un punto localizado tres millas inglesas tras Castillo Viejo". Como el general Alexander observó al demarcar el límite, el Tratado se refiere al río "en condiciones normales del agua", como un "canal del comercio" (parágrafo 73). Para la Corte, los artículos II y VI, entendidos conjuntamente, indican que el banco derecho 
del canal del río forma el límite, asumiendo que el canal sea navegable como canal del comercio. Así, los derechos de navegación de Costa Rica están ligados a la soberanía sobre el banco derecho, que claramente se le ha atribuido a Costa Rica hasta la desembocadura del río.

77. Costa Rica argumenta que, aunque ningún canal del río San Juan fluye hoy hasta la laguna de Harbor Head, no ha existido un cambio significativo en el lecho del canal principal del bajo río San Juan desde los laudos Alexander. Costa Rica sostiene que el territorio en el banco derecho del canal hasta la desembocadura del río en el mar Caribe debe considerarse como de soberanía costarricense. Según Costa Rica, no se le debe dar importancia alguna a lo que considera un caño artificial excavado por Nicaragua en 2010 con el fin de conectar el río San Juan con la laguna de Harbor Head.

78. Nicaragua sostiene que, como resultado de modificaciones naturales a la configuración geográfica del territorio disputado, el "primer canal" al que se refería el general Alexander en su primer laudo, es ahora un canal que conecta al río, en un punto al sur de la laguna de Harbor Head, con el extremo sur de tal laguna. El canal en cuestión, según Nicaragua, es el caño que dragó en 2010 solo para mejorar la navegabilidad. Basado en la alegada existencia de este caño por un número de años y sosteniendo que hoy constituye el límite, Nicaragua reclama soberanía sobre el territorio disputado.

79. Según Nicaragua, la existencia del caño antes de 2010 es confirmada por imágenes de satélite, en particular, Nicaragua alega que una foto de satélite de 1961 muestra que un caño ya existía donde Nicaragua dragó en 2010.

80. Costa Rica indica que, especialmente a razón de la densa vegetación, las fotos de satélites y fotos aéreas del territorio en disputa no son claras, incluyendo la foto de 1961. Más aún, Costa Rica presenta una foto de satélite de agosto de 2010, que descartaría la existencia del canal en el período entre la limpieza de la vegetación en el lugar del caño y el dragado del caño. En los procedimientos orales, Nicaragua admitió que, por el follaje de los árboles, solo una inspección al terreno daría certeza sobre el caño.

81. En la opinión de la Corte, una inspección difícilmente sería útil para reconstruir la situación anterior a 2010. La Corte considera que, dada la falta general de claridad de las imágenes satelitales o aéreas, y el hecho de que los canales que pueden ser identificados en esas imágenes no corresponden a la localización del caño dragado en 2010, esta evidencia 
es insuficiente para probar un canal natural que uniera al río San Juan con la laguna de Harbor Head siguiendo el mismo curso que el caño que fue dragado.

82. Para probar la opinión de que el caño ya existía por algún tiempo antes de que fuera dragado, Nicaragua provee tres declaraciones juramentadas de policías y militares nicaragüenses que refieren una corriente que unía al río San Juan con la laguna y afirman que era navegable por un período durante el año. Algunas declaraciones juramentadas de otros agentes mencionan una corriente en el área de la laguna y describen que era navegable por botes, pero no especifican su ubicación.

83. La Corte recuerda que, "al determinar el valor como evidencia de cualquier declaración por parte de un individuo, la Corte necesariamente toma en consideración su forma y las circunstancias en las que fue realizada" —aplicabilidad de la Convención sobre la Prevención y el Castigo del Crimen de Genocidio (Croacia c. Serbia), sentencia del 3 de febrero de 2015, para. 196 — . Las declaraciones juramentadas serán tratadas "con precaución" en particular aquellas hechas por oficiales gubernamentales para propósitos del litigio (ibíd., paras. 196-197, en referencia a "Disputa territorial y marítima entre Nicaragua y Honduras en el mar Caribe (Nicaragua c. Honduras), sentencia, ICJ Reports 2007, (II), p. 731, para. 244). En el presente caso, la Corte encuentra que las declaraciones juramentadas de oficiales gubernamentales nicaragüenses, que fueron preparadas posteriormente a la solicitud de procedimientos por parte de Costa Rica, le dan poco soporte a la objeción de Nicaragua.

84. Nicaragua se refiere a un mapa producido en 1949 por el Instituto de Geografía Nacional de Costa Rica que muestra un caño en la ubicación del que fue dragado en 2010. También reconoce que el mapa describe el territorio en disputa en su integridad como de soberanía costarricense. Nicaragua posteriormente invoca un mapa publicado en 1971 por el mismo instituto que muestra una frontera cercana a la línea alegada por Nicaragua. Aun así, la Corte nota que esta evidencia se contradice con múltiples mapas oficiales de Nicaragua, en particular un mapa de 1967 de la Dirección de Cartografía y un mapa, de 2003, publicado por el Instituto Nicaragüense de Estudios Territoriales (INETER), que muestra el área en disputa como de soberanía costarricense.

85. Como sostuvo la Comisión de Límites en el caso Eritrea/Etiopía, en una sección que fue citada con la aprobación de la Corte en el caso concerniente a la soberanía sobre Pedra Branca/Pulau Batu Puteh, Middle Rocks y South Ledge (Malasia/Singapur), un mapa "constituye 
una afirmación de un hecho geográfico, especialmente cuando el Estado adversamente afectado lo ha producido y diseminado, incluso en contra de su propio interés" (sentencia, ICJ Reports 2008, p. 95, para. 271). En el caso presente, la evidencia de mapas publicados por las partes en general da soporte a la posición de Costa Rica, pero su significado es limitado, dado que son de muy pequeña escala y no se enfocan en los detalles del territorio en disputa.

86. Ambas partes invocan effectivités para corroborar sus pretensiones de soberanía territorial. Costa Rica sostiene que ha ejercido soberanía sobre el territorio en disputa sin ser interrumpida hasta 2010. Costa Rica recuerda que adoptó legislación aplicable especialmente al área, que expidió permisos o títulos para el uso de la tierra en ese territorio y que la Isla Portillos fue incluida dentro del área que había designado como humedal de importancia internacional bajo la Convención de Ramsar (Humedal Caribe Noreste). Costa Rica indica también que, cuando Nicaragua registró su propio humedal de importancia internacional relativo al área (Refugio de Vida Silvestre Río San Juan), solo incluyó la laguna de Harbor Head y no involucró el territorio en disputa.

87. Nicaragua, por su parte, objeta que es ella quien ha actuado como soberana sobre el territorio en disputa. Mediante declaraciones juramentadas de oficiales gubernamentales y dos reportes policiales, sostiene que por lo menos desde 1970 el Ejército de Nicaragua, la Marina y su Policía han patrullado el área dentro y alrededor de la laguna de Harbor Head, incluyendo los caños que conectan la laguna con el río San Juan.

88. Costa Rica cuestiona el valor de tal evidencia de Nicaragua para sustentar su argumento de haber ejercido poderes soberanos sobre el territorio en disputa.

Nicaragua sostiene que el ejercicio de soberanía reclamado por Costa Rica se limita a una mera presencia en el papel en el territorio disputado, no soportada por ninguna conducta real en el terreno.

89. Las effectivités invocadas por las partes, que la Corte considera son de relevancia limitada, no pueden afectar el título de soberanía resultante del Tratado de 1858 y de los laudos Cleveland y Alexander.

90. La Corte nota que la existencia por un significativo lapso de tiempo de un caño navegable en la ubicación reclamada por Nicaragua se pone en cuestión por el hecho de que en el lecho del canal había arboles de considerable tamaño y edad que habían sido limpiados por Nicaragua en 2010. Más aún, como fue denotado por el experto principal de Costa Rica, si el canal hubiese sido una ramificación del río San Juan, "el sedimento 
hubiera llenado, o mínimamente o parcialmente ocupado, la parte más al sur de la laguna". Adicionalmente, el hecho de que, como concuerdan los expertos de las partes, el caño dragado en 2010 no continuaba conectando el río con la laguna para el verano de 2010 levanta dudas sobre la existencia por cierto número de años de un canal navegable que siguiera la misma ruta antes de que Nicaragua desarrollara sus actividades de dragado. Este caño difícilmente pudo ser el canal navegable de comercio mencionado anteriormente (parágrafo 76).

91. Si las pretensiones de Nicaragua fueran aceptadas, Costa Rica se vería impedida de disfrutar de su soberanía territorial sobre el banco derecho del río San Juan hasta su desembocadura, contrario a lo establecido en el Tratado de 1858 y el laudo Cleveland. Adicionalmente, según el artículo VI del Tratado de 1858 (citado en el parágrafo 133), los derechos de navegación de Costa Rica están sobre las aguas del río y el banco derecho que forma el límite entre los dos países. Como lo anota la Corte (parágrafo 76), esos derechos de navegación están ligados a la soberanía sobre el banco derecho.

92. La Corte concluye entonces que el banco derecho del caño que Nicaragua dragó en 2010 no hace parte del límite entre Costa Rica y Nicaragua, y que el territorio bajo soberanía de Costa Rica se extiende al banco derecho del bajo río San Juan hasta la desembocadura en el mar Caribe. La soberanía sobre el territorio en disputa pertenece a Costa Rica.

93. No se objeta que Nicaragua llevó a cabo varias actividades en el territorio en disputa desde 2010, incluyendo excavar tres caños y establecer presencia militar en partes de tal territorio. Esas actividades fueron en violación de la soberanía territorial costarricense. Nicaragua es responsable por esas violaciones y, consecuentemente, incurre en la obligación de reparar el daño causado por sus actividades ilícitas (ver sección E).

94. Costa Rica sostiene que, "al ocupar y reclamar territorio de Costa Rica, Nicaragua también violó otras obligaciones”.

95. La petición final de Costa Rica 2(b)(iv) solicita a la Corte que juzgue y declare que Nicaragua violó la obligación de "no usar el río San Juan para llevar a cabo actos hostiles", bajo el artículo IX del Tratado de 1858, que indica lo siguiente:

"Por ningún motivo, ni en caso y estado de guerra, en que por desgracia llegasen a encontrarse las repúblicas de Nicaragua y Costa Rica, les será permitido ejercer ningún acto de hostilidad entre ellas en el puerto de San Juan del Norte, ni en el río de este nombre y lago de Nicaragua". 
No se presentó ninguna evidencia de hostilidades en el río San Juan. Por ello, la pretensión relativa a la violación por parte de Nicaragua a sus obligaciones bajo el artículo IX del Tratado es rechazada.

96. En su pretensión final 2(b)(ii), Costa Rica le pide a la Corte decidir que Nicaragua ha violado la "prohibición de la amenaza o uso de la fuerza bajo el artículo 2(4) de la Carta de las Naciones Unidas y el artículo 22 de la Carta de la Organización de Estados Americanos".

97. La conducta relevante de Nicaragua ya ha sido abordada en el contexto del examen de la Corte sobre la violación de la integridad territorial de Costa Rica. El hecho de que Nicaragua considerase que sus actividades estaban teniendo lugar en su propio territorio no excluye la posibilidad de caracterizarlas como un uso ilegal de la fuerza. Esto genera el interrogante sobre su compatibilidad tanto con la Carta de las Naciones Unidas como con la Carta de la Organización de Estados Americanos. Sin embargo, en las presentes circunstancias, dado que el carácter ilícito de estas actividades ya ha sido establecido, la Corte no necesita adentrarse más a fondo en esta pretensión. Como en el caso relativo a la Frontera terrestre y marítima entre Camerín y Nigeria (Camerún c. Nigeria; Guinea Ecuatorial como interviniente), la Corte encuentra que, "por el solo hecho del presente fallo y de la evacuación" del territorio en disputa, el perjuicio sufrido por Costa Rica "en todos los eventos habrá sido suficientemente resuelto" (ICJ Reports 2002, p. 452, para. 319).

98. En su pretensión final 2(b)(iii), Costa Rica le pide a la Corte que decida que Nicaragua hizo que el territorio de Costa Rica fuera "objeto, aun de manera temporal, de ocupación militar, contrario al artículo 21 de la Carta de la Organización de Estados Americanos". La primera frase de esta disposición prevé: "El territorio de un Estado es inviolable; no puede ser objeto de ocupación militar ni de otras medidas de fuerza tomadas por otro Estado, directa o indirectamente, cualquiera que fuere el motivo, aun de manera temporal".

Para fundamentar su reclamo, Costa Rica refiere a la presencia de personal militar de Nicaragua en el territorio en disputa.

99. La Corte ya ha establecido que la presencia de personal militar de Nicaragua en el territorio en disputa fue ilegal porque violó la integridad territorial de Costa Rica. La Corte no necesita analizar si esta conducta de Nicaragua constituye una ocupación militar en violación del artículo 21 de la Carta de la Organización de Estados Americanos. 


\section{B. Presuntas violaciones del derecho internacional ambiental}

100. La Corte pasará ahora al alegato de Costa Rica relativo a la violación por parte de Nicaragua de sus obligaciones bajo el derecho internacional ambiental en conexión con las actividades de dragado para mejorar la navegabilidad del río San Juan. Las alegaciones ambientales de Costa Rica pueden ser agrupadas en dos grandes categorías. Primero, de acuerdo con Costa Rica, Nicaragua violó la obligación procedimental de llevar a cabo un estudio de impacto ambiental transfronterizo apropiado en relación con los trabajos de dragado, y de notificar y consultar con Costa Rica sobre estos trabajos. En segundo lugar, Costa Rica alega que Nicaragua violó su obligación ambiental sustancial de no causar daño al territorio de Costa Rica. La Corte considerará los alegatos de Costa Rica uno a uno.

\section{Obligaciones procedimentales}

a) La presunta violación de la obligación de llevar a cabo un estudio de impacto ambiental

101. Las partes consienten en líneas generales la existencia bajo el derecho internacional general de una obligación de efectuar un estudio de impacto ambiental relativo a las actividades llevadas a cabo dentro de la jurisdicción del Estado que generen un riesgo de causar un daño significativo a otros Estados, particularmente en áreas o regiones que compartan condiciones ambientales.

102. Costa Rica alega que Nicaragua no ha cumplido con la obligación, y debe hacerlo de manera previa a cualquier dragado adicional. Señala en particular que el análisis realizado en el Estudio de impacto ambiental llevado a cabo en 2006 no apoya la conclusión de que el proyecto de dragado no causaría daño al caudal del río Colorado. Además, según Costa Rica, el Estudio de impacto ambiental no analizó el impacto del programa de dragado en los humedales. Costa Rica mantiene que los cambios artificiales a la morfología del río derivados de las actividades de dragado de Nicaragua están en riesgo de causar un impacto adverso en esos humedales. Costa Rica también argumenta que un documento titulado "Informe: Misión Ramsar de Asesoramiento No 72", preparado en abril de 2001, confirma la existencia de un riesgo de daño transfronterizo, demuestra que el es- 
tudio de Nicaragua no contiene un análisis del riesgo y concluye que ese análisis debió haberse efectuado antes de la implementación del programa de dragado.

103. Nicaragua alega, por su parte, que su Estudio de impacto ambiental de 2006 y la documentación relacionada abordó de manera completa el impacto transfronterizo potencial de su programa de dragado, incluyendo sus efectos en el medio ambiente de Costa Rica y la posible reducción en el caudal del río Colorado. Pone de presente que este estudio concluyó que el programa no generaba ningún riesgo de daño transfronterizo significativo y, en realidad, tendría efectos beneficiosos para el río San Juan y su área circundante. En relación con el documento titulado: "Informe: Misión Ramsar de Asesoramiento No 72", Nicaragua argumenta que este era solo una borrador de informe, en relación con el cual Nicaragua presentó observaciones en término, pero que la Oficina de la Convención de Ramsar nunca finalizó; en consecuencia, no se le debe otorgar ningún valor. Adicionalmente, Nicaragua explica que la conclusión del informe según la cual no hubo ningún análisis del impacto del programa de dragado en la hidrología del área era incorrecto, como lo puso de presente en sus comentarios ante la Oficina de la Convención de Ramsar.

104. Como la Corte tuvo ocasión de enfatizar en su fallo en el caso de las plantas de celulosa en el río Uruguay (Argentina c. Uruguay):

El principio de prevención, una regla del derecho internacional consuetudinario, tiene sus orígenes en la debida diligencia que se requiere del Estado en su territorio. Es la "obligación de todo Estado no permitir a sabiendas que su territorio sea usado para actos contrarios a los derechos de otros Estados" —Canal de Corfú (Reino Unido c. Albania), méritos, fallo, ICJ Reports 1949, p. 22-. Por lo tanto, un Estado está obligado a usar todos los medios a su disposición para evitar que actividades que tienen lugar en su territorio, o en cualquier área bajo su jurisdicción, causen un daño significativo al medio ambiente de otro Estado —ICJ Reports 2010, (I), pp. 55-56, para. 101—.

Adicionalmente, la Corte concluyó en ese caso que "podría considerarse hoy un requisito bajo el derecho internacional general llevar a cabo un estudio de impacto ambiental cuando existe un riesgo de que la actividad industrial propuesta pueda tener un impacto adverso significativo en un contexto extraterritorial, en particular, en un recurso compartido" —ICJ Reports 2010, (I), p. 83, para. 204_. Aunque la manifestación de la 
Corte en el caso de las plantas de celulosa se refiere a actividades industriales, el principio subyacente aplica de manera general a posibles actividades que pueden ocasionar un impacto adverso significativo en un contexto extraterritorial. Entonces, para cumplir su obligación de ejercer la debida diligencia en la prevención de un daño ambiental transfronterizo significativo, un Estado debe, antes de embarcarse en una actividad que tenga el potencial de afectar adversamente el medio ambiente de otro Estado, averiguar si existe un riesgo de un daño transfronterizo significativo, que activaría el requisito de llevar a cabo un estudio de impacto ambiental.

La determinación del contenido del estudio de impacto ambiental debe realizarse a la luz de las circunstancias específicas de cada caso. Como lo señaló la Corte en el caso de las plantas de celulosa:

"Le corresponde a cada Estado determinar, en su legislación doméstica o en el proceso de autorización del proyecto, el contenido específico del estudio de impacto ambiental requerido en cada caso, teniendo en consideración la naturaleza y magnitud del proyecto propuesto y su potencial impacto adverso en el medio ambiente, así como sobre la necesidad de ejercer la debida diligencia en la realización de ese estudio" — ICJ Reports 2010, (I), p. 83, para. 205-.

Si el estudio de impacto ambiental confirma que existe un riesgo de un daño transfronterizo significativo, el Estado que planea llevar a cabo la actividad debe, de conformidad con su obligación de debida diligencia, notificar y consultar en buena fe a los Estados potencialmente afectados, cuando esto sea necesario para determinar las medidas apropiadas para prevenir o mitigar ese riesgo.

105. La Corte observa que el riesgo a los humedales que alega Costa Rica se refiere a las actividades de dragados de Nicaragua como un todo, incluyendo el dragado del caño de 2010. La Corte recuerda que las actividades de dragado que se llevaron a cabo en violación de la soberanía territorial de Costa Rica han sido consideradas previamente. En consecuencia, la Corte limitará su análisis a determinar si las actividades de dragado de Nicaragua en bajo río San Juan conllevan un riesgo de daño transfronterizo significativo. El riesgo principal que cita Costa Rica fue el potencial impacto adverso de esas actividades de dragado en la corriente del río Colorado, lo cual también podría afectar adversamente sus humedales. En 2006, Nicaragua llevó a efecto un estudio sobre el impacto ambiental que el programa de dragado podría tener en su propio ambiente, el cual también señaló que el programa no causaría impactos significativos en el caudal del río Colorado. Habiendo examinado la evidencia en el expediente, 
incluyendo los informes y testimonios de los expertos llamados por las partes, la Corte encuentra que el programa de dragado planeado en 2006 no fue uno que generara un riesgo de daño transfronterizo significativo, ni en relación con la corriente del río Colorado ni con los humedales de Costa Rica. En vista de la ausencia de riesgo de daño significativo, Nicaragua no estaba obligada a llevar a cabo un estudio de impacto ambiental.

b) La presunta violación de la obligación de notificación y consulta

106. Las partes acuerdan sobre la existencia en el derecho internacional general de una obligación de notificación y consulta con los Estados potencialmente afectados en relación con actividades que conlleven un riesgo de daño transfronterizo significativo. Costa Rica alega que, además de sus obligaciones bajo el derecho internacional general, Nicaragua estaba bajo el deber de notificarle y consultarle como consecuencia de las obligaciones convencionales entre las partes. Primero, señala que el artículo 3, párrafo 2, y el artículo 5 de la Convención de Ramsar prevén un deber de notificación consulta. En segundo lugar, señala que los artículos 13(g) y 33 del Convenio para la Conservación de la Biodiversidad y Protección de Áreas Silvestres Prioritarias en América Central establece una obligación de compartir información relacionada con actividades que podrían ser particularmente nocivas para los recursos biológicos.

107. Aunque no niega la existencia de una obligación de notificación y consulta bajo el derecho internacional general, Nicaragua alega que en el presente caso esa obligación está limitada por el Tratado de 1858, según fue interpretado por el laudo Cleveland, el cual constituye la lex specialis con respecto a las obligaciones procedimentales. Para Nicaragua, ya que el Tratado de 1858 no contiene ningún deber de notificación o consulta en relación con el dragado o cualquier otro "trabajo de mejora", ningunos de esos deberes bajo el derecho consuetudinario o convencional aplica a los hechos de este caso. En cualquier evento, Nicaragua señala que el deber de notificación y consulta no se activaría porque los estudios de ambos países han demostrado que el programa de dragado de Nicaragua no presenta ninguna probabilidad de daño transfronterizo significativo. Más aún, Nicaragua argumenta que ni el artículo $3^{\circ}$, párrafo 2 , ni el artículo $5^{\circ}$ de la Convención de Ramsar es aplicable a los hechos del caso. Con respecto a la Conservación de la Biodiversidad y Protección de Áreas Silvestres Prioritarias en América Central, Nicaragua alega que no establece una obligación de compartir información relativa a actividades que puedan ser 
particularmente nocivas a los recursos biológicos; como mucho impulsa a los Estados a hacerlo.

108. La Corte observa que el hecho de que el Tratado de 1858 pueda contener obligaciones limitadas en relación con la notificación o consulta en situaciones específicas no excluye cualquier otra obligación procedimental con respecto al daño transfronterizo que pueda existir en el derecho internacional convencional o consuetudinario. En cualquier caso, la Corte encuentra que, ya que Nicaragua no estaba obligada bajo el derecho internacional a llevar a cabo un estudio de impacto ambiental a la luz de la ausencia de un riesgo de daño transfronterizo significativo (ver párrafo 105 arriba), no estaba obligada a notificar o consultar a Costa Rica.

109. En relación con la presunta existencia de una obligación de notificar y consultar conforme a tratados vinculantes para las partes, la Corte observa que tanto Costa Rica como Nicaragua son partes de la Convención de Ramsar y el Convenio para la Conservación de la Biodiversidad y Protección de Áreas Silvestres Prioritarias en América Central. La Corte recuerda que el artículo $3^{\circ}$, párrafo 2 , de la Convención de Ramsar prevé:

Cada parte contratante tomará las medidas necesarias para informarse lo antes posible acerca de las modificaciones de las condiciones ecológicas de los humedales situados en su territorio e incluidos en la lista, y que se hayan producido o puedan producirse como consecuencia del desarrollo tecnológico, de la contaminación o de cualquier otra intervención del hombre. Las informaciones sobre dichas modificaciones se transmitirán sin demora a la organización o al gobierno responsable de las funciones de la [Oficina de la Convención de Ramsar].

Aunque esta disposición contiene una obligación de notificación, esa obligación se limita a notificar a la Oficina de cambios o posibles modificaciones "de las condiciones ecológicas de los humedales" en el territorio del Estado notificante. En el presente caso, la evidencia ante la Corte no indica que el programa de dragado de Nicaragua haya traído cambios en el carácter ecológico del humedal, o que fuera probable que los generara a menos que se expandiera. Por eso, la Corte encuentra que no surge para Nicaragua ninguna obligación de informar a la Oficina de la Convención de Ramsar. 
110. La Corte recuerda adicionalmente que el artículo $5^{\circ}$ de la Convención de Ramsar prevé:

\section{Artículo 5}

Las partes contratantes celebrarán consultas sobre el cumplimiento de las obligaciones que se deriven de la Convención, especialmente en el caso de un humedal que se extienda por los territorios de más de una parte contratante o de un sistema hidrográfico compartido por varias de ellas. Al mismo tiempo, se esforzarán por coordinar y apoyar activamente las políticas y regulaciones actuales y futuras relativas a la conservación de los humedales y de su flora y fauna.

Aunque esta disposición contiene una obligación general de consultar "sobre el cumplimiento de las obligaciones que se deriven de la Convención", no crea una obligación para Nicaragua de consultar con Costa Rica en relación con un proyecto en particular que esté desarrollando, en este caso el dragado del bajo río San Juan. A luz de lo anterior, Nicaragua no estaba obligada bajo la Convención de Ramsar a notificar o consultar con Costa Rica antes de comenzar el proyecto de dragado.

111. En relación con el Convenio para la Conservación de la Biodiversidad y Protección de Áreas Silvestres Prioritarias en América Central, la Corte no ve necesidad de llevar más adelante su estudio, ya que ninguna de las dos disposiciones invocadas por Costa Rica contiene una disposición vinculante de notificación o consulta.

\section{c) Conclusión}

112. A la luz de lo anterior, la Corte concluye que no ha sido establecido que Nicaragua haya violado alguna obligación procedimental frente a Costa Rica, bajo tratados o el derecho internacional consuetudinario sobre el medio ambiente. La Corte toma nota del compromiso de Nicaragua, formulado durante el curso de los procedimientos orales, de llevar a cabo un nuevo estudio de impacto ambiental antes de cualquier expansión sustancial de su actual programa de dragado. También valora la Corte que Nicaragua señaló que ese estudio incluiría un análisis del riesgo de daño transfronterizo, y que notificaría y consultaría a Costa Rica como parte de ese proceso. 


\section{Obligaciones sustanciales concernientes al daño transfronterizo}

113. La Corte ya ha determinado que Nicaragua es responsable por el daño causado por sus actividades en violación de la soberanía territorial de Costa Rica. Lo que resta por ser examinado es si Nicaragua es responsable por algún daño transfronterizo presuntamente causado por las actividades de dragado que han tenido lugar en áreas bajo soberanía territorial en el río San Juan Bajo y en su banco izquierdo.

114. Costa Rica señala que Nicaragua ha violado "la obligación de no dragar, desviar o alterar el curso del río San Juan, o llevar a cabo cualquier otra obra en el río San Juan, si esta causa daños al territorio de Costa Rica (incluyendo el río Colorado), su medio ambiente, o a los derechos de Costa Rica bajo el laudo Cleveland de 1888" — pretensión final, para. 2(c)(v) - . De acuerdo con Costa Rica, el programa de dragado ejecutado por Nicaragua en el bajo río San Juan violó las obligaciones de Nicaragua bajo el derecho internacional consuetudinario y causó daño a las tierras de Costa Rica en el banco derecho del río, así como al mismo río Colorado.

115. Nicaragua alega que el programa de dragado no ha causado ningún daño al territorio de Costa Rica, incluyendo el río Colorado. Argumenta que la ejecución de los programas de dragado ha sido beneficiosa para la sección dragada del río San Juan Bajo y para los humedales de relevancia internacional río abajo. Además, Nicaragua sostiene que, bajo una regla especial señalada en el laudo Cleveland y que aplica al río San Juan, incluso si se derivara algún daño para el territorio de Costa Rica como resultado de los trabajos para mantener y mejorar el río, las actividades de dragado no serían ilegales.

116. Ambas partes hicieron referencia al aparte del laudo Cleveland que se lee en los siguientes términos:

La República de Costa Rica no puede impedirle a la República de Nicaragua ejecutar a su propio costo y dentro de su propio territorio aquellos trabajos de mejoramiento, siempre que eso trabajos de mejoramiento no resulten en ocupación o inundación o daño del territorio de Costa Rica, o en la destrucción o impedimento grave de la navegación del río o de algunas de sus bifurcaciones en ningún punto en donde Costa Rica tenga derecho a navegarlo. La República de Costa Rica tiene el derecho de demandar indemnización por cualquier lugar que le pertenezca en el banco derecho del río San Juan que pueda ser ocupada sin su consentimiento, y por cualquier tierra en el mismo 
banco que pueda resultar inundada o dañada de cualquier otra forma como consecuencia de trabajos de mejoramiento — RLAA, Vol. XXVIII, p. 201, para. 3(6), cursivas en el original-

Ambas partes también se refirieron al siguiente aparte del mismo laudo:

"La República de Costa Rica puede negarle a la República de Nicaragua el derecho de desviar las aguas del río San Juan en caso de que esa desviación resultare en la destrucción o impedimento grave de la navegación del río o de alguna de sus bifurcaciones en cualquier punto donde Costa Rica tenga derecho a navegarlo" —ibíd., para. 3(9)—.

117. De acuerdo con Nicaragua, las afirmaciones del laudo Cleveland, citado anteriormente, deben ser entendidas en el sentido de que Nicaragua está en libertad de llevar a cabo cualquier actividad de dragado, posiblemente incluso si es dañino para Costa Rica. De otra parte, de acuerdo con Costa Rica, Nicaragua estaría bajo la obligación de pagar compensación por cualquier daño causado a Costa Rica, sea el daño significativo o no, y ya sea que Nicaragua hubiere sido diligente o no en asegurar que el medio ambiente de Costa Rica no fuera afectado; el daño causado por "eventos imprevistos e incontrolables" relacionado con actividades de dragado también tendría que ser compensado por Nicaragua. Costa Rica también argumentó que "todos los derechos y obligaciones de Nicaragua bajo el Tratado de 1858 y el laudo de 1888 deben ser interpretados a la luz de los principios para la protección del medio ambiente que se encuentran vigentes hoy" y que el Tratado y el laudo no "derogan la aplicación de las obligaciones medioambientales bajo principios generales de derecho o bajo tratados internacionales" que obligan a los Estados a no causar un daño transfronterizo significativo.

118. Como la Corte lo declaró en el caso de las plantas de celulosa, bajo el derecho internacional consuetudinario, "[u]n Estado está... obligado a usar todos los medios a su disposición para evitar que actividades que ocurren en su territorio, o en áreas bajo su jurisdicción, causen daño significativo al medio ambiente de otro Estado" — ICJ Reports 2010, (I), p. 56, para. 101; ver también Legalidad de la amenaza o uso de armas nucleares, opinión consultiva, ICJ Reports 1996, (I), pp. 241-242, para. 29-.

En cualquier caso, para la Corte, resultaría necesario abordar la cuestión de la relación entre el Tratado de 1858 según fue interpretado en el laudo Cleveland y la actual regla del derecho internacional consuetudinario en relación con el daño transfronterizo, pero solo si Costa Rica 
probara que el programa de dragado en el bajo río San Juan produce daño en el territorio de Costa Rica.

119. Costa Rica no ha aportado ninguna evidencia convincente de que los sedimentos dragados del río fueron depositados en el banco derecho. Costa Rica no ha probado tampoco que el programa de dragado causó daño a sus humedales (ver párrafo 109 arriba). Con respecto al alegato de Costa Rica según el cual "el programa de dragado ha tenido efecto significativo en el río Colorado", ya se ha indicado que las partes acordaron que en el denominado "Delta Colorado" el río Colorado recibe cerca del $90 \%$ de las aguas que fluyen a través del río San Juan (ver párrafo 56 arriba). Nicaragua estima que la desviación de agua del río Colorado debido al dragado del bajo río San Juan afectó menos del 2\% de las aguas que fluyen dentro del río Colorado. Ningún número mayor ha sido sugerido por Costa Rica. Su principal experto observó que "no existe evidencia de que el programa de dragado ha afectado significativamente los caudales del río Colorado". Costa Rica sí adujo evidencia indicando una reducción significativa en el flujo del río Colorado entre enero de 2011 y octubre de 2014. Sin embargo, la Corte considera que no se ha establecido un nexo causal entre esta reducción y el programa de dragado de Nicaragua. Como lo admite Costa Rica, otros factores pueden ser relevantes en decrecimiento del flujo, el más notable, la relativamente pequeña cantidad de pluviosidad en el período relevante. En cualquier caso, la desviación del agua debido al dragado del bajo río San Juan está lejos de impedir gravemente la navegación en el río Colorado, según se prevé en el párrafo 3(9) del laudo Cleveland, o de dañar en cualquier otra forma a Costa Rica.

120. Por lo tanto, la Corte concluye que la evidencia disponible no muestra que Nicaragua haya violado su obligación al realizar actividades de dragado en el bajo río San Juan.

\section{Cumplimiento de las medidas provisionales}

121. En sus pretensiones finales, Costa Rica alega que Nicaragua también ha violado sus “obligaciones emanadas de las órdenes de la Corte de medidas provisionales del 8 de marzo de 2011 y 22 de noviembre de 2013" — para. 2(c)(vi)—.

122. Por su parte, Nicaragua presentó algunas cuestiones relacionadas con el cumplimiento por parte de Costa Rica de algunas medidas provisionales adoptadas por la Corte, pero no le pidió a la Corte hacer ninguna determinación sobre este particular. 
123. En su orden de medidas provisionales del 8 de marzo de 2011, la Corte indicó que "cada parte debe abstenerse de enviar a, o mantener, en el territorio en disputa, incluyendo el caño, cualquier personal, sea civil, de policía o seguridad"; la Corte también le pidió a cada parte "abstenerse de cualquier acción que pudiera agravar o extender la disputa ante la Corte o hacerla más difícil de resolver" —ICJ Reports 2011, (I), p. 27, para. 86-.

124. Costa Rica argumentó que la presencia en el territorio en disputa de grandes grupos de civiles nicaragüenses, miembros de un movimiento ambiental, constituía una violación de la orden de 2011. Nicaragua niega esto. En su orden del 16 de julio de 2013, la Corte especificó que "la presencia de grupos organizados de nacionales nicaragüenses en el área en disputa aparejaba el riesgo de incidentes que podían agravar la... disputa" (ICJ Reports 2013, p. 240, para. 37).

125. Costa Rica sostuvo y Nicaragua después reconoció que la excavación del segundo y tercer caño tuvo lugar después de que la orden de 2011 fuera adoptada, que esta actividad le era atribuible a Nicaragua y, además, que se había instalado un acampamiento militar en el territorio en disputa, según había sido definido por la Corte. En las audiencias orales, Nicaragua también reconoció que la excavación del segundo y tercer caño representaba una violación de sus obligaciones bajo la orden de 2011.

126. La Corte ya analizó estos hechos en su orden del 22 de noviembre de 2013 (ICJ Reports 2013, pp. 364-365, paras. 45-46). Sin embargo, esa declaración fue simplemente instrumental para asegurar la protección de los derechos de las partes durante los procedimientos judiciales. El fallo en los méritos es el lugar apropiado para que la Corte analice el cumplimiento de las medidas provisionales. Así, contrario a lo que ha sido argumentado por Nicaragua, la inclusión en este fallo de una manifestación sobre la existencia de una violación no puede ser vista como "redundante". Tampoco puede decirse que cualquier responsabilidad por la violación ha cesado: lo que puede haber cesado es la violación, no la responsabilidad que emerge de esa violación.

127. Sobre la base de los hechos que no han sido refutados, la Corte, en consecuencia, encuentra que Nicaragua violó sus obligaciones bajo la orden del 8 de marzo de 2011 al excavar dos caños y establecer una presencia militar en el territorio en disputa.

128. La orden de la Corte del 22 de noviembre de 2013 requirió la adopción de las siguientes medidas por parte de Nicaragua: "Abstenerse de cualquier dragado y otras actividades en el territorio en disputa"; "Rellenar la zanja en la playa norte del caño oriental"; "Generar el retiro de 
cualquier personal, civil, de policía o seguridad, del territorio en disputa"; y "Generar el retiro y prevenir la entrada al territorio en disputa de personas privadas bajo su jurisdicción o control” (ICJ Reports 2013, p. 369, para. 59). Costa Rica no formuló ningún alegato sobre violaciones posteriores de ninguna de esas obligaciones, y solo sostuvo que algunas de las actividades de Nicaragua después de la orden violaban su obligación de no agravar la disputa, la cual había sido mencionada en la orden de 2011. A la luz de la evidencia disponible, la Corte no encuentra que se haya demostrado una violación a esa obligación.

129. De esta forma, la Corte concluye que Nicaragua actuó en violación de sus obligaciones bajo la orden de 2011 al excavar el segundo y tercer caño, y al establecer presencia militar en el territorio en disputa. La Corte observa que esta determinación es independiente de la conclusión expuesta arriba (ver sección A) según la cual la misma conducta también constituye una violación de la integridad territorial de Costa Rica.

\section{Derechos de navegación}

130. En sus pretensiones finales, Costa Rica también alega que Nicaragua ha violado "los derechos perpetuos de Costa Rica a la libre navegación en el río San Juan, de conformidad con el Tratado de Límites de 1858, el laudo Cleveland de 1888 y el fallo de la Corte del 13 de julio de 2009" — pretensión final, para. 2(c)(iii)—.

131. Nicaragua refuta la admisibilidad de esta pretensión, la cual considera no está cubierta por la demanda y con un objeto desconectado de la "disputa principal". Costa Rica señala que ya había solicitado en su demanda - para. 41(f) — que la Corte juzgue y declare que, "por su conducta, Nicaragua ha violado... la obligación de no prohibir la navegación en el río San Juan por parte de los nacionales de Costa Rica”.

132. La Corte observa que, aunque la pretensión de Costa Rica podría haber sido entendida como relacionada con las "actividades de dragado y canalización que se llevan a cabo por Nicaragua en el río San Juan”, al que se refiere el mismo párrafo de la demanda, el fraseo de la pretensión citada arriba no contiene ninguna restricción al efecto. La Corte considera que la pretensión final de Costa Rica en relación con los derechos de navegación es admisible. 
133. El artículo VI del Tratado de 1858 prevé:

La República de Nicaragua tendrá exclusivamente el dominio y sumo imperio sobre las aguas del río San Juan, desde su salida del lago hasta su desembocadura en el Atlántico, pero la República de Costa Rica tendrá en dichas aguas los derechos perpetuos de libre navegación, desde la expresada desembocadura, hasta tres millas inglesas antes de llegar al Castillo Viejo [con objetos de comercio] ya sea con Nicaragua o al interior de Costa Rica, por los ríos de San Carlos o Sarapiquí, o cualquier otra vía procedente de la parte que en la ribera del San Juan se establece corresponder a esta república. Las embarcaciones de uno u otro país podrán indistintamente atracar en las riberas del río, en la parte en que la navegación es común, sin cobrarse ninguna clase de impuestos, a no ser que se establezcan de acuerdo entre ambos gobiernos.

El laudo Cleveland contiene algunas referencias a los derechos de navegación de Costa Rica que fueron citados arriba (ver párrafo 116). En su fallo en la causa relativa a la controversia sobre derechos de navegación y derechos conexos (Costa Rica c. Nicaragua), la Corte señaló:

Dos tipos de navegación privada están ciertamente cubiertos por los derechos de libre navegación de conformidad con el artículo VI del Tratado de 1858: la navegación de embarcaciones que llevan bienes dirigidos a transacciones comerciales; y la de embarcaciones que llevan pasajeros, quienes pagan un precio diferente a un precio simbólico (o a quienes se les paga un precio) a cambio de los servicios prestados (ICJ Reports 2009, p. 2454, para. 73).

Aunque el lenguaje expreso del artículo VI del Tratado de 1858 solo consideró navegación con objetos de comercio, la Corte también observó que:

"no puede haber sido la intención de los autores del Tratado de 1858 despojar a los habitantes del banco costarricense del río, donde el banco constituye la frontera entre los dos Estados, del derecho a usar el río en la medida necesaria para satisfacer sus necesidades esenciales, incluso en relación con actividades de carácter no comercial, dada la geografía del área" (ibíd., p. 246, para. 79).

En la parte operativa del mismo fallo, la Corte encontró que: 
"los habitantes del banco costarricense del río San Juan tienen el derecho de navegar en el río entre las comunidades ribereñas para los propósitos de las necesidades esenciales de la vida diaria, las cuales requieren transporte expedito" —ibíd., p. 270, para. 156(f)—.

134. Costa Rica incluye, dentro de las presuntas violaciones de sus derechos de navegación, la emisión por parte de Nicaragua del Decreto 079-2009 del 1 de octubre de 2009, relativo a la navegación en el río San Juan. La interpretación de este decreto es objeto de controversia entre las partes: Costa Rica considera que el decreto tiene una aplicación general, mientras que Nicaragua alega que aplica solo a los botes turísticos. Aunque es claro que el decreto debe estar acorde con el artículo VI del Tratado de 1858 según fue interpretado por la Corte, la Corte observa que ninguna de las instancias de inferencia con los derechos de navegación específicamente alegados por Costa Rica se refiere a la aplicación del Decreto 079-2009. Por lo tanto, la Corte no está llamada a examinar este decreto.

135. Costa Rica alega que las violaciones a sus derechos de navegación ocurrieron en cinco ocasiones. Nicaragua hace énfasis en el reducido número de presuntas violaciones, pero no refuta dos de esos incidentes. En el primero, de febrero de 2013, un granjero ribereño y su tío fueron detenidos por varias horas en una puesto militar nicaragüense y sometidos a tratos humillantes. Este incidente se expone en una declaración juramentada. En el segundo incidente, de junio de 2014, agentes de Nicaragua le impidieron a un propietario costarricense y a algunos miembros de una cooperativa local agrícola navegar el río San Juan. Esto está soportado en cinco declaraciones juramentadas.

136. La Corte encuentra que Nicaragua no aportó una justificación convincente en relación con el artículo VI del Tratado de 1858 para la conducta de sus autoridades en estos dos incidentes relativos a la navegación del río San Juan por parte de habitantes del banco costarricense. La Corte concluye que los dos incidentes demuestran que Nicaragua violó los derechos de navegación de Costa Rica en el río San Juan, de conformidad con el Tratado de 1858. En atención a esta determinación, es innecesario para la Corte examinar los otros incidentes invocados por Costa Rica.

\section{E. Reparación}

137. Costa Rica le pide a la Corte ordenarle a Nicaragua "repeler, por medios de su propia elección, aquellas disposiciones del Decreto 079-2009 y las normas regulatorias del 1 de octubre de 2009 anexas que 
resultan contrarias a los derechos de libre navegación de Costa Rica de conformidad con el artículo VI del Tratado de Límites de 1858, el laudo Cleveland de 1888 y el fallo de la Corte del 13 de julio de 2009", y cesar todas las actividades de dragado en el río San Juan hasta tanto se cumplan ciertas condiciones — pretensiones finales, para. 3(a) y (b)—.

Adicionalmente, Costa Rica le pide a la Corte ordenarle a Nicaragua:

Hacer la reparación en la forma de una compensación por el daño material causado a Costa Rica, incluyendo, pero sin limitarse, a: i) el daño derivado de la construcción de caños artificiales y la destrucción de árboles y vegetación en el "territorio en disputa"; ii) el costo de las medidas de mitigación llevadas a cabo por Costa Rica en relación con esos daños...; el monto de la compensación será determinado en una fase posterior de estos procedimientos —ibíd., para. 3(c)—.

También se le pide a la Corte ordenar a Nicaragua "proporcionar satisfacción de manera que se alcance una reparación completa de los perjuicios causados a Costa Rica en una forma que será determinada por la Corte" —ibíd., para. 3(d)—y "proveer seguridades apropiadas y garantías de no repetición de la conducta ilícita de Nicaragua, en la forma en que la Corte lo ordene" —ibíd., para. 3(e)—. Finalmente, Costa Rica solicita una condena en costas que será considerada posteriormente en la presente sección.

138. A la luz de las conclusiones a las que llegó la Corte en las secciones $\mathrm{B}$ y D arriba, las solicitudes de Costa Rica dentro del párrafo 3(a) y (d) de sus pretensiones finales, relativas a la derogación del Decreto 079-2009 en relación con la navegación y la cesación de las actividades de dragado, respectivamente, no pueden otorgarse.

139. La declaración de la Corte de que Nicaragua violó la integridad territorial de Costa Rica al excavar tres caños y establecer presencia militar en el territorio en disputa proporciona una satisfacción adecuada por el daño no material sufrido por esta razón. Lo mismo aplica a la declaración de violación de las obligaciones bajo la orden de la Corte del 8 de marzo de 2011 sobre medidas provisionales. Finalmente, la declaración de violación de los derechos de navegación de Costa Rica en los términos determinados arriba en la sección D otorgan una satisfacción adecuada por la violación.

140. La solicitud sobre "seguridades apropiadas y garantías de no repetición" estuvo basada originalmente en la presunta "mala fe" 
de Nicaragua en el dragado del caño de 2010 y la posterior violación de sus obligaciones bajo la orden de 2011.

141. Como lo indicó la Corte en Derechos de navegación y derechos conexos, "no existe razón para suponer que un Estado cuya acción o conducta ha sido declarada ilícita por la Corte repetirá el acto o conducta en el futuro, ya que su buena fe debe presumirse" y, por lo tanto, seguridades y garantías de no repetición solo serán ordenadas "en circunstancias especiales" (ICJ Reports 2009, p. 267, para. 150). Aunque Nicaragua no cumplió con las obligaciones bajo la orden de 2011, es necesario tomar igualmente en consideración el hecho de que Nicaragua posteriormente cumplió con los requerimientos previstos en la orden del 22 de noviembre de 2013 de "abstenerse de dragar o cualquier otra actividad en el territorio en disputa" y de "generar el retiro de cualquier personal, civil, de policía o seguridad, del territorio en disputa" (ICJ Reports 2013, p. 369, para. 59). Es de esperar que Nicaragua adoptará la misma actitud en relación con la situación legal derivada del presente fallo, en particular a la luz del hecho de que la cuestión de la soberanía territorial sobre el territorio en disputa ahora ha sido resuelta.

142. Costa Rica tiene derecho a recibir compensación por los daños materiales causados por la violación de obligación por parte de Nicaragua, los cuales han sido analizados por la Corte. El daño material relevante y el monto de la compensación pueden ser analizados por la Corte únicamente en procedimientos separados. La Corte es de la opinión de que las partes deben adelantar negociaciones para llegar a un acuerdo en este asunto. Sin embargo, si no lograran llegar a un acuerdo dentro de 12 meses desde la fecha del presente fallo, la Corte determinará, a petición de cualquiera de las partes, el monto de la compensación sobre la base de alegatos escritos posteriores limitados a esta cuestión.

143. Costa Rica también le pide a la Corte ordenarle a Nicaragua:

"Pagar todas las costas y gastos incurridos por Costa Rica al solicitar y obtener la orden de medidas provisionales del 22 de noviembre de 2013, incluyendo, pero sin limitarse a, los honorarios y gastos de los abogados y expertos de Costa Rica, con intereses, sobre una base de completa indemnidad" — pretensiones finales, para. 3(f) —.

La razón especial para esta solicitud es que los procedimientos que condujeron a la orden del 22 de noviembre de 2013 presuntamente se 
debieron a las violaciones de Nicaragua de sus obligaciones bajo la orden del 8 de marzo de 2011.

144. De acuerdo con el artículo 64 del Estatuto, "[s]alvo que la Corte determine otra cosa, cada parte sufragará sus propias costas". Este artículo prevé que, como regla, las costas no se le cargan a ninguna de las partes, pero le da a la Corte el poder para ordenar que una de ellas pague algunas o todas las costas. Aunque la violación de Nicaragua de sus obligaciones bajo la orden de 2011 obligó a Costa Rica a iniciar unos nuevos procedimientos de medidas provisionales, la Corte encuentra que, tomando en consideración la totalidad de las circunstancias del caso, un fallo de costas a favor de Costa Rica, como esta lo ha solicitado, no sería apropiado.

\section{Asuntos en el caso Nicaragua c. Costa Rica}

145. La demanda presentada por Nicaragua el 22 de diciembre de 2011 (ver párrafo 9 arriba) refiere a la presunta violación por parte de Costa Rica de sus obligaciones procedimentales y sustanciales en conexión con la construcción de una carretera a lo largo del río San Juan. La Corte comenzará por considerar la presunta violación de las obligaciones procedimentales; después, abordará la presunta violación de las obligaciones sustanciales.

\section{A. La presunta violación de obligaciones procedimentales}

\section{La presunta violación de la obligación de llevar a cabo un estudio de impacto ambiental}

146. De acuerdo con Nicaragua, Costa Rica violó su obligación bajo el derecho internacional general de evaluar el impacto ambiental de la construcción de la carretera antes de comenzarla, particularmente a la luz de la extensión y ubicación de la carretera.

147. Costa Rica niega esta acusación. Argumenta que la construcción de la carretera no creó un riesgo de daño transfronterizo significativo a causa del vertimiento de sustancias dañinas en el río San Juan, y de cualquier otra forma en el territorio de Nicaragua, y que no existía un riesgo de que el río pudiera resultar afectado materialmente por las cantidades relativamente insignificantes de sedimento provenientes de la carretera.

148. Costa Rica también sostiene que estaba exenta del requisito de preparar un estudio de impacto ambiental debido al estado de emergencia 
creado por la ocupación de la Isla Portillos por parte de Nicaragua (ver párrafos 63-64 arriba). En primer lugar, Costa Rica argumenta que una emergencia puede exonerar a un Estado del requerimiento de llevar a cabo un estudio de impacto ambiental, ya sea porque el derecho internacional contiene un renvoi al derecho doméstico en este punto, o porque incluye una excepción en situaciones de emergencia. En segundo lugar, Costa Rica señala que la construcción de la carretera fue la respuesta apropiada a la situación de emergencia, porque hubiera facilitado acceso a los puestos de policía y las comunidades remotas ubicadas a lo largo del banco derecho del río San Juan, particularmente a la luz del riesgo real de confrontación militar con Nicaragua, lo cual le hubiera exigido a Costa Rica evacuar el área. De esa forma, Costa Rica alega que podía proceder con los trabajos de construcción sin un estudio de impacto ambiental.

149. En cualquier caso, Costa Rica sostiene que, incluso si hubiera estado requerida por el derecho internacional a llevar a cabo un estudio de impacto ambiental en este caso, cumplió con la obligación al efectuar un número de estudios de impacto ambiental, incluyendo un Estudio de diagnóstico ambiental en 2013.

150. En respuesta, Nicaragua argumenta que no existía una emergencia en buena fe. Señala que la carretera no está ubicada cerca del territorio en disputa, según se definió en la orden de la Corte del 8 de marzo de 2011, y que la emergencia fue declarada varios meses después del comienzo de los trabajos de construcción. Nicaragua argumenta también que no existe una excepción de emergencia frente a la obligación internacional de realizar un estudio de impacto ambiental. Agrega que de forma inapropiada Costa Rica busca apoyarse en una declaración de emergencia bajo su derecho doméstico para justificar el incumplimiento de sus obligaciones internacionales.

151. Finalmente, Nicaragua señala que los estudios de impacto ambiental producidos por Costa Rica después de que la mayor parte de los trabajos de construcción se habían completado no constituyen un estudio de impacto ambiental adecuado. Como consecuencia, le pide a la Corte declarar que Costa Rica no debe llevar a cabo futuros desarrollos en el área sin un estudio de impacto ambiental apropiado.

152. Siguiendo las líneas de argumentación presentadas por las partes, la Corte examinará, en primer lugar, si Costa Rica tenía la obligación de llevar a cabo un estudio de impacto ambiental bajo el derecho internacional general. Y, de ser así, la Corte analizará si estaba exonerada 
de esa obligación o si cumplió con esta al efectuar el Estudio de diagnóstico ambiental y otros estudios.

153. La Corte recuerda (ver párrafo 104 arriba) que la obligación del Estado de ejercer la debida diligencia en la prevención del daño transfronterizo significativo requiere que el Estado examine si existe un riesgo de daño transfronterizo significativo antes de llevar a cabo una actividad que tenga el potencial de afectar adversamente el medio ambiente de otro Estado. Si ese es el caso, el Estado concernido debe efectuar un estudio de impacto ambiental. La obligación en cuestión le corresponde al Estado que realiza la actividad. En concordancia, en el presente caso, le correspondía a Costa Rica, no a Nicaragua, evaluar la existencia de un riesgo de daño transfronterizo significativo antes de la construcción de la carretera, sobre la base de una evaluación objetiva de todas las circunstancias relevantes.

154. En los procedimientos orales, el abogado de Costa Rica manifestó que una evaluación preliminar del riesgo presentado por el proyecto de la carretera se había realizado cuando se tomó la decisión de construir la carretera. De acuerdo con Costa Rica, esta evaluación tomó en consideración la naturaleza del proyecto y su impacto probable en el río, y concluyó que la carretera no representaba un riesgo de daño significativo. En apoyo a esta reclamación, Costa Rica enfatiza la escala modesta del proyecto, que la carretera claramente no era una autopista, que una parte de ella estaba construida en caminos preexistentes y que el único riesgo posible era la contribución de sedimento de la carretera en un río que ya llevaba una fuerte carga de sedimentos.

La Corte observa que llevar a cabo un análisis preliminar del riesgo representado por una actividad es una de las formas en que un Estado puede determinar si una actividad conlleva un riesgo de daño transfronterizo significativo. Sin embargo, Costa Rica no ha aducido ninguna evidencia de que en efecto llevó a cabo ese análisis preliminar.

155. Al evaluar si, para el final de 2010, la construcción de la carretera representaba un riesgo de daño transfronterizo significativo, la Corte deberá tener en consideración la naturaleza y magnitud del proyecto y el contexto en el cual iba a llevarse cabo.

Primero, la Corte observa que, contrario a lo manifestado por Costa Rica, la escala del proyecto de carretera era sustancial. La carretera, que tiene aproximadamente $160 \mathrm{~km}$, corre a lo largo del río por 108,2 km (ver 
mapa 2). Aproximadamente la mitad de esa extensión corresponde a una construcción completamente nueva.

En segundo lugar, la Corte observa que, debido a la planeación de la ubicación de la carretera a lo largo del río San Juan, cualquier daño causado por la carretera al medio ambiente circundante podría afectar fácilmente el río, y, por lo tanto, el territorio de Nicaragua. La evidencia ante la Corte demuestra que aproximadamente la mitad de la extensión de la carretera a lo largo del río San Juan está situada dentro del rango de 100 metros del banco del río; por casi $18 \mathrm{~km}$ está ubicado dentro del rango de 50 metros del río; y, en algunos sectores, llega hasta los 5 metros del banco derecho del río. La ubicación de la carretera en tan cercana proximidad del río y el hecho de que a menudo se construiría en pendientes generan riesgo de un incremento de descarga de sedimentos dentro del río. Otro factor relevante al evaluar la probabilidad de sedimentación debido a la erosión de la carretera es que casi un cuarto de la carretera fue construida en áreas que fueron previamente forestadas. La posibilidad de desastres naturales en el área como consecuencia de eventos adversos, tales como huracanes, tormentas tropicales y terremotos, que elevarían el riesgo de erosión sedimentaria, deben tomarse igualmente en consideración.

Tercero, las condiciones geográficas de la cuenca del río en donde la carretera se situaría deben tomarse en cuenta. La carretera pasaría a lo largo de un humedal de importancia regional en el territorio de Costa Rica y se localizaría en cercana proximidad de otro humedal protegido - el Refugio de Vida Silvestre del Río San Juan — situado en el territorio de Nicaragua. La presencia de sitios Ramsar protegidos eleva el riesgo de daño significativo, porque denota que el medio ambiente receptor es particularmente sensible. El daño principal que podía generarse era un potencial vertimiento extensivo de sedimentos de la carretera, con riesgos resultantes para la ecología y la calidad del agua del río, así como cambios morfológicos.

156. En conclusión, la Corte encuentra que la construcción de la carretera por parte de Costa Rica conllevaba un riesgo de daño transfronterizo significativo. Por lo tanto, el umbral para activar la obligación de evaluar el impacto ambiental de la carretera se cumplió.

157. La Corte pasará ahora la pregunta de si Costa Rica estaba eximida de su obligación de evaluar el impacto ambiental del proyecto de carretera debido a una emergencia. Primero, la Corte recuerda su posición 
según la cual "le corresponde a cada Estado determinar en su legislación doméstica o en el proceso de autorización del proyecto, el contenido específico del estudio de impacto ambiental requerido en cada caso", teniendo en consideración varios factores - ver párrafo 104 arriba, citando Plantas de celulosa en el río Uruguay (Argentina c. Uruguay), fallo, ICJ Reports 2010, (I), p. 83, para. 205-. La Corte observa que esta referencia al derecho doméstico no se relaciona con la cuestión de si un estudio de impacto ambiental debe realizarse. Así, el hecho de que pueda existir una excepción de emergencia en el derecho de Costa Rica no afecta la obligación de Costa Rica bajo el derecho internacional de llevar a cabo un estudio de impacto ambiental.

158. En segundo lugar, con independencia de la cuestión de si una emergencia podía eximir a un Estado de su obligación bajo el derecho internacional de llevar a cabo un estudio de impacto ambiental, o diferir la ejecución de esta obligación hasta que la emergencia haya cesado, la Corte considera que, en las circunstancias de este caso, Costa Rica no ha demostrado la existencia de una emergencia que justifique la construcción de una carretera sin llevar a cabo un estudio de impacto ambiental. De hecho, la terminación del proyecto iba a ser requerida, como en efecto lo está requiriendo, varios años. Adicionalmente, cuando Costa Rica se embarcó en la construcción de la carretera, la situación en el territorio en disputa se había sometido ante la Corte, la cual poco después emitió medidas provisionales. Aunque Costa Rica sostiene que la construcción de la carretera tenía como propósito facilitar la evacuación del área de territorio costarricense contiguo al río San Juan, la Corte observa que la carretera proporciona acceso solo a una parte del área y, por lo tanto, solo de forma limitada podía constituir una respuesta a la presunta emergencia. Adicionalmente, Costa Rica no ha demostrado una amenaza inminente de confrontación militar en las regiones que la carretera atraviesa. Finalmente, la Corte observa que el decreto ejecutivo que proclamó la emergencia fue emitido por Costa Rica el 21 de febrero de 2011, después de que los trabajos en la carretera ya habían comenzado.

159. Habiendo concluido que, en las circunstancias de este caso, no existía una emergencia que justificara la construcción inmediata de la carretera, la Corte no ve necesidad de decidir si hay una excepción de emergencia frente a la obligación de llevar a cabo un estudio de impacto ambiental en los casos en que exista un riesgo de daño transfronterizo significativo.

Se sigue que Costa Rica estaba bajo la obligación de llevar a cabo un estudio de impacto ambiental antes de comenzar los trabajos de construcción. 
160. Pasando ahora a la pregunta de si Costa Rica cumplió con su obligación de realizar un estudio de impacto ambiental, la Corte observa que Costa Rica produjo varios estudios, incluyendo un Plan de Manejo Ambiental para la carretera en abril de 2012, un Estudio de diagnóstico ambiental en noviembre de 2013 y un estudio de seguimiento en enero de 2015. Estos estudios analizaron los efectos adversos que ya habían sido causados por la construcción de la carretera en el medio ambiente y sugirieron pasos para prevenirlos o reducirlos.

161. En el fallo en el caso de las plantas de celulosa, la Corte señaló que la obligación de llevar a cabo un estudio de impacto ambiental es de carácter continuado, y que se debe realizar un monitoreo de los efectos del proyecto en el medio ambiente, cuando sea necesario, a lo largo de la vida del proyecto — ICJ Reports 2010, (I), pp. 83-84, para. 205-. Sin embargo, la obligación de llevar a cabo un estudio de impacto ambiental precisa de una evaluación ex ante del riesgo de daño transfronterizo significativo, $y$, de esta forma, "un estudio de impacto ambiental debe llevarse a cabo antes de la implementación de un proyecto" (ibíd., p. 83, para. 205). En el presente caso, Costa Rica estaba bajo la obligación de efectuar ese análisis antes de comenzar la construcción de la carretera, para asegurar que el diseño de ejecución del proyecto minimizaría el riesgo de daño transfronterizo significativo. En contraste, el Estudio de diagnóstico ambiental de Costa Rica y los otros estudios fueron análisis post hoc del impacto ambiental de las secciones de la carretera que ya se habían construido. Estos estudios no evaluaron el riesgo de daño futuro. La Corte observa además que el Estudio de diagnóstico ambiental fue llevado a cabo aproximadamente tres años después de la construcción de la carretera.

162. Por las razones anteriores, la Corte concluye que Costa Rica no ha cumplido con su obligación bajo el derecho internacional general de llevar a cabo un estudio de impacto ambiental relativo a la construcción de la carretera.

\section{La presunta violación del artículo 14 del Convenio sobre la Diversidad Biológica}

163. Nicaragua alega que Costa Rica estaba obligada a llevar a cabo un estudio de impacto ambiental en virtud del artículo 14 del Convenio sobre la Diversidad Biológica. Costa Rica responde que la disposición en 
cuestión refiere a la introducción de procedimientos apropiados en relación con proyectos que tienen la probabilidad de tener un efecto significativo adverso en la diversidad biológica. Costa Rica alega que disponía de esos procedimientos y que, en cualquier caso, no aplican a la construcción de carreteras, ya que no tenía la potencialidad de generar efectos adversos en la diversidad biológica.

164. La Corte recuerda la parte relevante de la disposición mencionada:

1. Cada parte contratante, en la medida de lo posible y según proceda:

a) Establecerá procedimientos apropiados por los que se exija la evaluación del impacto ambiental de sus proyectos propuestos que puedan tener efectos nocivos adversos importantes para la diversidad biológica con miras a evitar o reducir al mínimo esos efectos y, cuando proceda, permitirá la participación del público en esos procedimientos.

La Corte considera que la disposición bajo análisis no crea una obligación de llevar a cabo un estudio de impacto ambiental antes de efectuar una actividad que pueda tener efectos significativos adversos en la diversidad biológica. Por lo tanto, no ha sido establecido que Costa Rica haya violado el artículo 14 del Convenio sobre la Diversidad Biológica al no realizar un estudio de impacto ambiental para su proyecto de carretera.

\section{La presunta violación de la obligación de notificación y consulta}

165. Nicaragua alega que Costa Rica violó su obligación de notificación y consulta con Nicaragua en relación con los trabajos de construcción. Nicaragua establece la existencia de esta obligación en tres bases, a saber, el derecho internacional consuetudinario, el Tratado de 1858 y la Convención de Ramsar. La Corte examinará cada uno de los argumentos de Nicaragua a su turno.

166. En la posición de Nicaragua, Costa Rica le debió haber notificado el proyecto de carretera y le debió haber consultado, ya que Costa Rica tenía todas las razones para creer que la construcción de la carretera 
creaba un riesgo significativo de daño transfronterizo. De acuerdo con Nicaragua, la presunta emergencia no eximía a Costa Rica de esta obligación.

167. Para Costa Rica, el umbral de "riesgo de impacto transfronterizo adverso" no se cumplió en este caso. Adicionalmente, Costa Rica alega haber invitado a Nicaragua a adelantar consultas, pero Nicaragua no lo hizo. En cualquier caso, de acuerdo con Costa Rica, Nicaragua está impedida de invocar la obligación de notificación, ya que ella misma ha creado la emergencia a la que Costa Rica tuvo que responder mediante la construcción de la carretera.

168. La Corte recuerda su conclusión según la cual, si el estudio de impacto ambiental confirma que existe un riesgo de daño transfronterizo significativo, un Estado que planea una actividad que acarrea un riesgo tal debe, para cumplir su obligación de ejercer la debida diligencia en la prevención del daño transfronterizo significativo, notificar y consultar al Estado potencialmente afectado de buena fe, cuando eso sea necesario para determinar las medidas apropiadas para prevenir o mitigar ese riesgo (ver párrafo 104 arriba). Sin embargo, el deber de notificación y consulta no requiere examen por parte de la Corte en el presente caso, puesto que la Corte ha establecido que Costa Rica no ha cumplido con su obligación bajo el derecho internacional general de llevar a cabo un estudio de impacto ambiental antes de la construcción de la carretera.

169. Nicaragua también afirma la existencia de una obligación de notificación bajo el Tratado de 1858. En su fallo de 2009 en el caso sobre los derechos de navegación, la Corte sostuvo que Nicaragua tiene una obligación de notificar a Costa Rica sobre sus regulaciones relativas a la navegación en el río. De acuerdo con Nicaragua, dado que la carretera afecta los derechos de navegación de Nicaragua, el mismo razonamiento aplica a fortiori en este caso.

170. Para Costa Rica, la referencia de Nicaragua al Tratado de 1858 es incorrecta, ya que el Tratado no impone a Costa Rica una obligación de notificar a Nicaragua en el evento en que Costa Rica lleve a cabo trabajos de infraestructura en su propio territorio.

171. La Corte recuerda su determinación en el fallo de 2009 en el sentido de que la obligación de Nicaragua de notificar a Costa Rica bajo el Tratado de 1858 surge, entre otros factores, por virtud de los derechos de navegación de Costa Rica en el río, el cual es parte de territorio de 
Nicaragua (ICJ Reports 2009, pp. 251-252, paras. 94-97). En contraste, el Tratado de 1858 no le otorga a Nicaragua ningún derecho en el territorio de Costa Rica en donde se localiza la carretera. Por lo tanto, no surge ninguna obligación de notificar a Nicaragua en relación con las medidas que Costa Rica lleva a cabo en su territorio. La Corte concluye que el Tratado de 1858 no impone a Costa Rica una obligación de notificar a Nicaragua la construcción de la carretera.

172. Finalmente, Nicaragua se basa en el artículo $3^{\circ}$, párrafo 2 , y en el artículo $5^{\circ}$ de la Convención de Ramsar (ver párrafos 109-110 arriba), al señalar que estos imponen una obligación de notificación y consulta a los Estados partes. En consideración de la Corte, Nicaragua no ha demostrado que, al construir la carretera, Costa Rica haya modificado o era probable que modificara el carácter ecológico de los humedales situados en su territorio. Más aún, contrario al alegato de Nicaragua, en febrero de 2012 Costa Rica notificó a la Oficina de la Convención de Ramsar sobre el sector de la carretera que pasa a través del Humedal Caribe Noreste. Por lo tanto, la Corte concluye que Nicaragua no ha demostrado que Costa Rica violó el artículo $3^{\circ}$, párrafo 2 , de la Convención de Ramsar. En relación con el artículo $5^{\circ}$ de la Convención de Ramsar, la Corte encuentra que esta disposición no crea una obligación a cargo de Costa Rica de consultar a Nicaragua en relación con un proyecto específico que esté adelantando, en este caso la construcción de la carretera (ver también párrafo 110 arriba).

173. En conclusión, la Corte encuentra que Costa Rica no cumplió con su obligación de evaluar el daño impacto ambiental de la construcción de la carretera. Costa Rica continúa estando obligada a preparar un estudio de impacto ambiental apropiado para cualquier trabajo futuro en la carretera o en un área contigua al río San Juan, si es que este apareja un riesgo de daño transfronterizo significativo. Costa Rica acepta que está vinculada por esta obligación. No existe razón para suponer que no tomará nota del razonamiento y conclusiones en este fallo en la medida en que realice cualquier desarrollo en el área, incluyendo trabajos ulteriores de construcción en la carretera. La Corte también toma nota del compromiso de Nicaragua, efectuado en el curso de los procedimientos, en el sentido 
de cooperar con Costa Rica en la evaluación del impacto de esos trabajos en el río. En este sentido, la Corte considera que, si las circunstancias así lo requieren, Costa Rica tendrá que consultar en buena fe a Nicaragua, que es soberana sobre el río San Juan, para determinar las medidas apropiadas a fin de prevenir un daño transfronterizo significativo o minimizar el riesgo.

\section{B. Presuntas violaciones de las obligaciones sustanciales}

174. La Corte pasa ahora al examen de las presuntas violaciones por parte de Costa Rica de sus obligaciones sustanciales bajo el derecho internacional consuetudinario y las convenciones internacionales aplicables. En particular, Nicaragua alega que la construcción de la carretera causó daño al río San Juan, el cual está bajo soberanía de Nicaragua de acuerdo con el Tratado de 1858. Así, en opinión de Nicaragua, Costa Rica violó la obligación bajo el derecho internacional consuetudinario de no causar un daño transfronterizo significativo a Nicaragua, la obligación de respetar la integridad territorial de Nicaragua y otras obligaciones convencionales sobre protección del medio ambiente.

175. Durante los últimos cuatro años, las partes han presentado ante la Corte una vasta cantidad de material fáctico y científico en apoyo a sus respectivos alegatos. También han presentado numerosos reportes y estudios preparados por expertos y consultores, comisionados por cada Estado en relación con asuntos como los estándares técnicos para la construcción de carreteras; morfología de ríos; niveles de sedimentación en el río San Juan, sus causas y efectos; el impacto ecológico de la construcción de la carretera; y el estatus de los trabajos de recuperación llevados a cabo por Costa Rica. Algunos de estos especialistas también han comparecido ante la Corte para aportar evidencia en su capacidad de expertos de conformidad con los artículos 57 y 64 del Reglamento de la Corte.

176. Es deber de la Corte, después de darle la debida consideración a toda la evidencia en el expediente, evaluar su valor probatorio, para determinar qué hechos deben ser considerados relevantes y derivar conclusiones a partir de ellos en la medida de lo pertinente. Apegándose a esta práctica, la Corte hará sus propias determinaciones sobre los hechos, sobre la base de la totalidad de la evidencia presentada ante ella, y luego aplicará las reglas relevantes del derecho internacional a los hechos que haya considerado probados - Plantas de celulosa en el río Uruguay (Argentina c. Uruguay), sentencia, ICJ Reports 2010, (I), p. 72, para. 168-. 


\section{La presunta violación de la obligación de no causar daño transfronterizo significativo a Nicaragua}

177. Nicaragua alega que los trabajos de construcción resultaron en el vertimiento de grandes cantidades de sedimento dentro del río San Juan, en particular, debido a que Costa Rica descartó principios básicos de ingeniería, se generó una erosión significativa. Por ejemplo, Costa Rica llevó a cabo una deforestación extensiva en áreas adyacentes al río, así como movilizaciones de tierra que condujeron a la creación de cortes inestables y rellenos en las proximidades del río. Además, los constructores de la carretera dejaron pilas de tierra expuestas a la lluvia y no construyeron sistemas de drenaje adecuados y senderos para evitar la erosión. Más aún, Nicaragua sostiene que el sector de la carretera a lo largo de río San Juan está ubicado demasiado cerca del río — casi la mitad de ella fue construida a una distancia de 100 metros del río, y algunas partes incluso a 5 metros del banco del río- o en colinas inclinadas (steep slopes), incrementando de esa forma el aporte de sedimentos en el río. El principal experto de Nicaragua opinó que la erosión es particularmente severa en el sector situado en el kilómetro 4,16 de la carretera en donde se ubican las secciones más empinadas, entre un punto denominado "Hito II" (el punto occidental desde donde el banco derecho del río San Juan marca la frontera con Nicaragua) y Boca San Carlos (en la unión de los ríos San Juan y San Carlos; ver mapa 2).

178. Según Nicaragua, el vertimiento de grandes cantidades de sedimento en el río San Juan causó un incremento en las concentraciones de sedimentos en él, que hoy en día ya se han elevado de forma no natural. Nicaragua señala que este incremento, en y por sí mismo, produjo un daño en el río, ya que el sedimento es un contaminante, y tiene diversos efectos adversos. Primero, produjo cambios en la morfología del río, pues grandes cantidades de sedimento erosionado de la carretera se acumularon en el lecho del bajo río San Juan, exacerbando de esta forma los problemas para la navegación de este sector del río y haciendo necesario dragados adicionales para restaurar la navegabilidad del canal. Adicionalmente, el sedimento erosionado de la carretera creó grandes deltas a lo largo del banco costarricense del río que obstruyen la navegación. Segundo, Nicaragua argumenta que la construcción de la carretera ha tenido un impacto adverso en el turismo y la salud de las comunidades ribereñas. También sostiene Nicaragua que el continuo incumplimiento por parte de Costa Rica de los estándares de construcción expone a Nicaragua a un daño futuro, 
y que Costa Rica no ha adoptado las medidas de mitigación apropiadas. Más aún, Nicaragua alega que se derivan riesgos adicionales de la posibilidad de derrames de materiales tóxicos en el río, el desarrollo posterior del banco costarricense y la probabilidad de desastres naturales causados por eventos adversos, tales como huracanes, tormentas tropicales y terremotos.

179. Por su parte, Costa Rica señala que la construcción de la carretera no ha causado ningún daño a Nicaragua. Según Costa Rica, la erosión es un proceso natural y el sedimento no es un contaminante. Alega que Nicaragua no ha aducido ninguna evidencia de un daño real al río, menos de un daño significativo. Adicionalmente, Costa Rica argumenta que la contribución de sedimento de la carretera es diminuta comparada con la carga de sedimento existente en el río. También recuerda que, desde el año 2012, ha llevado a cabo trabajos de mitigación para evitar la erosión en las pendientes y en los cruces de los cursos de agua (tales como la construcción de terraplenes en las pendientes, cavado de canales de dragado, instalación de drenajes cruzados en la carretera, construcción de trampas de sedimentos y reemplazo de los puentes de madera por puentes modulares), con el objetivo de reducir en mayor medida la cantidad de sedimento de la carretera que llega hasta el río San Juan.

180. Para pronunciarse sobre los alegatos de Nicaragua, la Corte, primero, abordará los argumentos de las partes sobre la contribución de sedimentos de la carretea al río; después, examinará si el sedimento derivado de la carretera causó un daño significativo a Nicaragua.

\section{a) La contribución de sedimento de la carretera al rio}

181. Las partes acuerdan que el sedimento erosionado de la carretera llega al río, pero están en considerable desacuerdo frente al volumen real.

182. Nicaragua sostiene que el método más directo y confiable para evaluar la cantidad total de sedimento aportado por la carretera al río es estimar el volumen de sedimento que entra al río desde todos los sitios a lo largo de la carretera que están sujetos a erosión. Argumenta, basada en las estimaciones de sus expertos principales, que la totalidad del sedimento que llega al río es aproximadamente entre 190.000 y 250.000 toneladas por año, incluyendo el sedimento erosionado desde los caminos de acceso que conectan la carretera con las áreas internas. Nicaragua indica, adicionalmente, que el volumen de sedimento en el río debido a la construcción de la carretera se incrementaría en un factor mínimo de diez durante una tormenta tropical o un huracán. 
183. Costa Rica refuta las estimaciones de sedimento presentadas por Nicaragua. En particular, argumenta, con base en la evidencia de su perito experto, que los expertos de Nicaragua sobreestimaron las áreas sujetas a erosión, las cuales ellos no podían medir directamente debido a que la carretera está en territorio de Costa Rica. Añade que los estimativos de Nicaragua se inflaron como consecuencia de la inclusión de las vías o caminos de acceso, los cuales no contribuyen con ninguna cantidad apreciable de sedimento al río San Juan. Según Costa Rica, la contribución de sedimento desde la carretera es de aproximadamente 75.000 toneladas por año. En la posición de Costa Rica, incluso este número es una sobreestimación porque no toma en consideración los efectos de los trabajos de mitigación que recientemente se han llevado a cabo. Finalmente, Costa Rica sostiene que los expertos de Nicaragua han sobrevalorado el riesgo de lluvias sin precedentes y los impactos de cargas de sedimentos en el río como resultado de huracanes y tormentas tropicales.

184. Costa Rica señala que el método más directo y confiable para medir el impacto de la carretera en las concentraciones de sedimento en el río San Juan hubiera sido que Nicaragua, que es soberana sobre el río, llevara a cabo un programa de muestreo. Sin embargo, Nicaragua no ha aportado mediciones de sedimentación y de niveles de flujo en el río. La única información empírica ante la Corte son dos reportes del Instituto Nicaragüense de Estudios Territoriales (INETER), los cuales contienen mediciones de tasas de flujo y concentraciones de sedimento suspendido tomados en varias locaciones a lo largo del río San Juan en 2011 y 2012. Costa Rica argumenta que ninguna de las mediciones demuestra algún impacto de la carretera.

185. Nicaragua respondió que un programa de muestreo no hubiera sido de ayuda para evaluar el impacto de la carretera a causa de la sedimentación, porque la base sedimentaria del río San Juan antes de la construcción de la carretera es desconocida.

186. La Corte observa que no se ha refutado que el sedimento erosionado de la carretera se deposita en el río. En relación con el volumen total de sedimento aportado por la carretera, la Corte observa que la evidencia ante ella está basada en modelaciones y estimativos de expertos designados por las partes. La Corte también observa que existe un desacuerdo considerable entre los expertos en relación con información clave, tal como las áreas sujetas a erosión y las tasas apropiadas de erosión, que los llevaron a adoptar conclusiones diferentes en relación con la cantidad total de sedimento aportado por la carretera. La Corte no ve 
necesidad de adentrarse en un examen detallado de la validez científica y técnica de los diferentes estimativos presentados por los expertos de las partes. Es suficiente notar que la cantidad de sedimento en el río debida a la construcción de la carretera representa al menos un 2\% de la carga sedimentaria del río, según los cálculos aportados por Costa Rica y basados en los números proporcionados por el experto de Nicaragua y que no fueron refutados por esta (ver párrafos 182 a 183 y 188 a 191 arriba). La Corte volverá sobre este punto más abajo (ver párrafo 194), después de considerar otros argumentos de las partes.

\section{b) Si el sedimento derivado de la carretera causó un daño significativo a Nicaragua}

187. El principal interrogante ante la Corte es si la construcción de la carretera por parte de Costa Rica ha causado un daño significativo a Nicaragua. La Corte comenzará su análisis considerando el hecho de que la totalidad del sedimento del río se hubiera incrementado como resultado de la construcción de la carretera en y por sí mismo, causando un daño significativo a Nicaragua. La Corte examinará, posteriormente, si ese incremento en las concentraciones de sedimento causó daño, en particular a la morfología del río, a la navegación y a los programas de dragado de Nicaragua; la calidad del agua y el ecosistema acuático; o si causó cualquier otro daño que pueda ser significativo.

i. Presunto daño causado por el incremento en la concentración de sedimento en el río

188. Nicaragua alega que el volumen (cantidad abstracta) de sedimento erosionado de la carretera, con independencia de su cantidad total, contaminó el río, causando un daño significativo a Nicaragua. En la posición de Nicaragua, el impacto del aporte sedimentario de la carretera debe ser considerado tomando en cuenta la elevada carga de sedimentos en río San Juan, la cual presuntamente se debe a la deforestación y a las precarias prácticas agrarias de Costa Rica. Un experto de Nicaragua estimó la carga sedimentaria actual en aproximadamente 13.700 .000 toneladas por año. En este contexto, Nicaragua sostuvo que existe una carga máxima de sedimento en el río San Juan, y que cualquier cantidad adicional de sedimento aportado desde la carretera al río resultaría necesariamente dañina. 
189. Costa Rica responde que Nicaragua no ha demostrado que el río San Juan tenga una capacidad máxima de sedimento que ha sido superada. Para Costa Rica, el interrogante ante la Corte es si el impacto relativo del sedimento derivado de la carretera en el total de la carga sedimentaria de río San Juan causó un daño significativo. Costa Rica alega que no. Según Costa Rica, el río San Juan lleva naturalmente una pesada carga de sedimento, la cual es atribuible a la geología de la región, y, en particular, a la ocurrencia de terremotos y erupciones volcánicas en el área de dragado del río y sus afluentes. El volumen de sedimento aportado por la carretera es insignificante en el contexto de la carga total de sedimento del río (estimado por Costa Rica en 12.678.000 toneladas por año), representando un mero 0,6\% como máximo. El sedimento derivado de la carretera es también indiscernible tomando en consideración la alta variabilidad de las cargas sedimentarias del río que derivan de otras fuentes. Costa Rica añade que, incluso si las cifras de Nicaragua pudieran aceptarse, el aporte sedimentario debido a la construcción de la carretera seguiría representando una pequeña proporción únicamente, dentro del orden del 1-2\% del total de carga transportada por el río San Juan. En opinión de Costa Rica, esta cantidad es demasiado pequeña para tener un impacto significativo.

190. Nicaragua también argumenta, sobre la base de los comentarios al proyecto de artículos de la Comisión de Derecho Internacional en Relación con la Prevención del Daño Transfronterizo Resultante de Actividades Peligrosas, que cualquier impacto nocivo de la construcción de la carretera en el río San Juan debe ser susceptible de medición para calificar como daño significativo. Dado que la cantidad de sedimento en el río derivado de la construcción de la carretera es cuantificable, como lo demostró el hecho de que tanto los expertos de Costa Rica como los de Nicaragua hayan estimado su cantidad, esta última alega que aquel ha causado un daño significativo.

191. Costa Rica replica que Nicaragua no ha demostrado un daño significativo mediante estándares fácticos y objetivos. También argumenta que, incluso careciendo de la línea de base apropiada, Nicaragua podía haber medido el impacto de la construcción de la carretera en las concentraciones de sedimento del río tomando sus propias medidas río arriba y río abajo desde los trabajos de construcción. Sin embargo, Nicaragua no lo hizo. 
192. En consideración de la Corte, la posición de Nicaragua, según la cual cualquier impacto nocivo en el río que sea susceptible de cuantificación constituye un daño significativo, es infundada. El sedimento se encuentra de manera natural en el río en grandes cantidades, y Nicaragua no ha demostrado, que los niveles de sedimento en el río son tales, que la introducción de sedimentos adicionales erosionados desde la carretera generan una suerte de nivel crítico en términos de sus efectos perjudiciales. Además, la Corte determina que, contrario a las pretensiones de Nicaragua, el presente caso no concierne a una situación en donde el sedimento aportado por la carretera excedió el nivel máximo permitido, lo que no ha sido determinado en relación con el río San Juan. Así, la Corte no está convencida con el argumento de Nicaragua según el cual la cantidad bruta de sedimento en el río debido a la construcción de la carretera causó un daño significativo per se.

193. Por lo tanto, la Corte procederá a considerar el impacto relativo del sedimento derivado de la carretera en la actual carga total del río San Juan. En este sentido, la Corte observa que la carga total sedimentaria del río San Juan no ha sido establecida. En efecto, Nicaragua no ha proporcionado medidas directas de los niveles de sedimento en el río. Costa Rica, basada en el reporte de su principal experto, estimó la carga total de sedimento del río en aproximadamente 12.678.000 toneladas por año, usando mediciones del río Colorado. Nicaragua no ha aportado una figura comparable, aunque su experto señaló que el nivel total de carga sedimentaria del río San Juan es de aproximadamente 13.700.000 toneladas por año.

194. Sobre la base de la evidencia ante ella, y tomando en cuenta los estimados aportados por los expertos sobre la cantidad de sedimento en el río debido a la construcción de la carretera y el total de carga de sedimento del río San Juan, la Corte observa que la carretera contribuye al menos en un $2 \%$ de la carga total del río. La Corte considera que no puede inferirse un daño significativo a partir de ello, particularmente tomando en consideración la alta variabilidad natural en las cargas de sedimento del río.

195. En cualquier caso, en consideración de la Corte, las únicas mediciones que se encuentran ante ella, a saber, aquellas contenidas en los reportes INETER de 2011 y 2012, no apoyan la pretensión de Nicaragua según la cual el sedimento erosionado desde la carretera ha tenido un impacto significativo en las concentraciones de sedimento en el río. Unas comparaciones de las mediciones tomadas en 2011, cuando la mayoría de la carretera no se había construido aún, y en 2012, cuando los trabajos de construcción estaban en marcha, demuestra que los niveles de sedimento en el río son variables, y que los afluentes (particularmente los ríos San 
Carlos y Sarapiqui) son fuentes mayores de sedimento para el San Juan. Sin embargo, la información no indica un impacto significativo en los niveles de sedimento a causa de la construcción de la carretera. Adicionalmente, las mediciones tomadas en El Castillo y río arriba de Boca San Carlos, que son representativas de los puntos más inclinados de la carretera, no demuestran un impacto significativo.

196. A la luz de lo anterior, la Corte concluye que Nicaragua no ha establecido el hecho de que las concentraciones de sedimento en el río se hubieran incrementado a causa de la construcción de la carretera por sí y en sí misma, causando un daño transfronterizo significativo.

ii. Presunto daño a la morfología del río, a la navegación y los programas de dragado nicaragüense

197. La Corte examinará si el sedimento, aportado por la carretera, corresponde como máximo al $2 \%$ del promedio total de carga del río, causó un daño significativo. El argumento primario de Nicaragua sobre el daño causado por la construcción de la carretera refiere al impacto del sedimento en la morfología del río, particularmente en el bajo río San Juan.

198. Las partes en general están de acuerdo en que, asumiendo que en el "Delta Colorado" el 10\% de las aguas del río San Juan fluyen dentro del bajo río San Juan, aproximadamente un 16\% de los sedimentos suspendidos y un $20 \%$ de la carga pesada en el río San Juan fluirían dentro del bajo río San Juan. También están de acuerdo en que, a diferencia del más extenso río Colorado, el bajo río San Juan carece de una capacidad de reserva para transportar el sedimento. Así, el sedimento pesado se deposita en el lecho del bajo río San Juan. Los expertos de las partes también concuerdan en que el sedimento que se asienta en el lecho del río no se esparce de manera homogénea, sino que tiende a acumularse en bancos de arena que pueden obstruir la navegación, especialmente en la temporada seca. Sin embargo, las partes están en desacuerdo sobre si, y en que extensión, los sedimentos suspendidos más finos también se depositan en el lecho del río y, de manera más general, sobre los efectos de la construcción de la carretera en el vertimiento de sedimentos en el bajo río San Juan.

199. De acuerdo con el experto de Nicaragua, todo el sedimento pesado y un $60 \%$ del sedimento fino aportado por la carretera al bajo río San Juan se asienta en el lecho del río. Para mantener la navegabilidad del río, Nicaragua debe dragar el sedimento fino y pesado que se acumula en el bajo río San Juan. En opinión de Nicaragua, en un río que ya está 
sobrecargado con sedimento, como el bajo río San Juan, cualquier adición de sedimento que provenga de la carretera causa un daño significativo a Nicaragua, porque incrementa la carga de dragado. Adicionalmente, la acumulación de sedimento derivado de la carretera reduce el flujo de agua fresca a los humedales río abajo, los cuales dependen del balance ecológico.

200. Nicaragua también argumenta que el sedimento erosionado de la carretera creó deltas "gigantes" a lo largo del canal del río que obstruyen la navegación, causando de esta forma un daño significativo a Nicaragua.

201. Costa Rica responde, con base en la evidencia de su principal experto, que la acumulación de sedimentos en el bajo río San Juan es un fenómeno natural inevitable que no está relacionado con la construcción de la carretera. Para Costa Rica, el experto presentado por Nicaragua sobreestimó dramáticamente la cantidad de sedimento derivado de la carretera que se deposita en el bajo río San Juan. En primer lugar, según Nicaragua, únicamente el sedimento pesado se acumula en el lecho del río, mientras que la mayoría del sedimento liviano se desplaza hasta el mar Caribe. En segundo lugar, Costa Rica argumenta que no existe evidencia de que el sedimento pesado derivado de la carretera haya alcanzado efectivamente el bajo río San Juan. La deposición de sedimentos no es un proceso lineal; en particular, el sedimento tiende a acumularse en estrechos del río denominados "depósitos" o "response reaches" y puede permanecer allí por varios años antes de ser transportado más abajo en el canal. Además, Costa Rica indica que los estimativos de las partes se basan en varias suposiciones sin corroboración, incluyendo estimativos sobre la separación de flujos y las cargas de sedimentos entre el río Colorado y el bajo río San Juan en el "Delta Colorado". Costa Rica argumenta adicionalmente que la posición de Nicaragua frente al daño descansa en una suposición incorrecta, según la cual el sedimento que se acumula en el lecho del río San Juan necesariamente requería ser dragado.

202. En relación con los deltas a lo largo del banco costarricense del río, Costa Rica sostiene que Nicaragua no ha demostrado que fueron creados como resultado de la construcción de la carretera. Por ejemplo, las imágenes satelitales demuestran que al menos dos de esos deltas preceden a la carretera. Costa Rica también señala que existen deltas similares en el banco nicaragüense de la carretera. En cualquier caso, su impacto en la morfología del río y en la navegación es insignificante debido a su tamaño relativamente pequeño en relación con el ancho del río. 
203. La Corte observa que Nicaragua no ha aportado prueba directa sobre cambios en la morfología del bajo río San Juan o de un deterioro en su navegación desde que comenzó la construcción de la carretera. El caso de Nicaragua se basa en modelos y estimaciones por parte de sus expertos, los cuales no han sido sustanciados sobre la base de datos empíricos. La Corte observa en este sentido que existe una incertidumbre importante en relación con el volumen de sedimento erosionado desde la carretera y que presuntamente ha llegado al bajo río San Juan y se ha depositado en su lecho. Por ejemplo, Nicaragua no ha aducido evidencia científica sobre la división del flujo y de las cargas de sedimento en el "Delta Colorado", sino que basó sus estimaciones en un reporte del Instituto Costarricense de Electricidad, el cual a su vez se basó en mediciones tomadas únicamente del río Colorado.

204. La Corte también considera que la evidencia experta ante ella establece que la acumulación de sedimento es una característica natural perdurable en el bajo río San Juan, y que el aporte de sedimento a lo largo del San Juan no es un proceso linear. El sedimento derivado de la carretera es uno en un número de factores que pueden tener un impacto en la acumulación de sedimentos en el bajo río San Juan. Por lo tanto, la Corte considera que la evidencia presentada por Nicaragua no prueba que cualquiera de los cambios morfológicos en el bajo río San Juan haya sido causado por la construcción de la carretera en particular.

205. En relación con la pretensión de Nicaragua según la cual la construcción de la carretera ha tenido un impacto significativo adverso en la carga de dragado, la Corte indica que Nicaragua no ha aducido ninguna evidencia sobre un incremento en sus actividades de dragado debido a la construcción de la carretera. En este sentido, la Corte también recuerda que Nicaragua inició su programa de dragado antes de que la construcción de la carretera comenzara (ver párrafos 63-64 arriba). En cualquier caso, la Corte recuerda su conclusión en el sentido de que la construcción de la carretera ha causado un incremento en las concentraciones de sedimento en el río correspondientes como máximo a un 2\% (ver párrafo 194 arriba). La Corte observa que no existe evidencia de que el sedimento derivado de la construcción de la carretera tenga mayor probabilidad de asentarse en el lecho del río, que el sedimento emanado de otras fuentes. Así, el sedimento proveniente de la carretera correspondería como máximo al $2 \%$ del sedimento dragado por Nicaragua en el río San Juan. De esta forma, la Corte no está convencida de que el sedimento emanado de la carretera 
haya llevado a un incremento significativo del nivel del lecho del bajo río San Juan o en la carga de dragado de Nicaragua.

206. Finalmente, la Corte pasa a analizar el alegato de Nicaragua según el cual los deltas de sedimento a lo largo del banco costarricense del río han causado un daño significativo en la morfología del río y en la navegación. En consideración de la Corte, la evidencia fotográfica aducida por Nicaragua indica que existen deltas en el banco costarricense del río a los cuales la construcción de la carretera les aporta sedimentos. La Corte observa que Nicaragua señaló que en el punto más inclinado de la carretera existen ocho deltas "gigantes", pero no pudo especificar el número total de deltas que presuntamente fueron creados como consecuencia de la construcción de la carretera. La Corte también indica que las imágenes satelitales en el expediente demuestran que al menos dos de estos deltas preceden la carretera. En cualquier caso, la Corte considera que Nicaragua no ha presentado suficiente evidencia para probar que estos deltas, que únicamente ocupan el borde del canal del río en el banco costarricense, hayan tenido un impacto significativo adverso en la morfología del río o en la navegación.

207. Por las razones anteriores, la Corte concluye que Nicaragua no ha acreditado que el sedimento aportado por la carretera ha causado un daño significativo en la morfología y navegabilidad del río San Juan y en el bajo río San Juan, ni tampoco que ese sedimento haya incrementado significativamente la carga de dragado de Nicaragua.

iii. Presunto daño a la calidad del agua y al ecosistema acuático

208. La Corte considerará ahora el alegato de Nicaragua en relación con el daño a la calidad del agua y al ecosistema acuático. En sus alegatos escritos, Nicaragua arguyó que las acrecentadas concentraciones de sedimento en el río como resultado de la construcción de la carretera causaron un daño significativo a las especies de peces, muchas de las cuales pertenecen a familias que son vulnerables a niveles elevados de sedimentos, a los macroinvertebrados y a las comunidades de algas del río. Adicionalmente, de acuerdo con Nicaragua, el sedimento de la carretera causó un deterioro en la calidad del agua del río. Para probar el daño a los organismos acuáticos y a la calidad del agua, Nicaragua se basó inter alia en un reporte experto fundado en las muestras en 16 deltas del río, las cuales concluyeron que tanto la riqueza de especies como la abundancia 
de los macroinvertebrados eran significativamente más bajos en el banco sur que en el banco norte.

209. Durante el curso de los procedimientos orales, la posición de Nicaragua cambió frente a su inicial de daño real al ecosistema del río, para alegar un riesgo de daño. Las partes ahora concuerdan que no ha habido estudios de especies de peces en el río San Juan para determinar si ellos son vulnerables a niveles elevados de sedimentos. Sin embargo, Nicaragua alega que el Estudio de diagnóstico ambiental de Costa Rica y el estudio de seguimiento realizado en enero de 2015 por parte del Centro de Ciencia Tropical (en adelante ССT) demuestran que la carretera dañó a los macroinvertebrados y la calidad del agua en los afluentes que fluyen dentro del río San Juan. El CCT midió la calidad del agua en los afluentes costarricenses río arriba y río abajo de la carretera y registró una menor calidad de agua río abajo de la carretera. Para Nicaragua, esto demuestra un riesgo de daño al río mismo debido al impacto acumulativo de esos afluentes.

210. Para Costa Rica, el caso de Nicaragua en relación con el impacto sobre especies de peces es defectuoso debido a la falta de evidencia sobre daño real. Apelando a uno de sus expertos, Costa Rica argumenta que es muy probable que las especies que viven en el río estén adaptadas a condiciones en donde hay altas y variables cargas de sedimento, y que sean altamente tolerantes a esas condiciones. En relación con los macroinvertebrados y la calidad del agua, Costa Rica señala que el estudio del CCT no demuestra ningún impacto significativo. En cualquier caso, sus resultados están basados en muestras de pequeños arroyos afluentes en Costa Rica, y no pueden ser transpuestos al mucho más grande río San Juan. Adicionalmente, Costa Rica argumenta que el reporte experto aducido por Nicaragua no proporciona soporte suficiente al alegato de Nicaragua según el cual la construcción de la carretera ha tenido un impacto adverso en los macroinvertebrados que viven en los deltas a lo largo del banco sur del río.

211. La Corte observa que Nicaragua no ha presentado ninguna evidencia de daño real a los peces en el río San Juan, y tampoco ha identificado con precisión qué especies de peces han sido presuntamente dañadas por la construcción de la carretera.

212. En consideración de la Corte, el Estudio de diagnóstico ambiental invocado por Nicaragua solo demuestra que la construcción de la carretera ha tenido un impacto localizado en las comunidades de macroinvertebra- 
dos y en la calidad del agua en pequeños arroyuelos de Costa Rica que se drenan al interior del río San Juan. Sin embargo, la Corte no está persuadida de que los resultados del Estudio de diagnóstico ambiental y el estudio de seguimiento pueden ser traspasados al río San Juan, el cual tiene un promedio de ancho de casi 300 metros. En relación con el reporte experto presentado por Nicaragua, la Corte encuentra difícil atribuir cualquier diferencia en la riqueza de macroinvertebrados y abundancia entre los bancos norte y sur del río a la construcción de la carretera únicamente, en vez de también a otros factores, como el tamaño del área de pesca y los niveles de nutrientes.

213. A la luz de las consideraciones anteriores, la Corte encuentra que Nicaragua no ha probado que la construcción de la carretera causó un daño significativo a los ecosistemas del río y a la calidad del agua.

iv. Otros presuntos daños

214. Nicaragua también alega que la construcción de la carretera ha tenido un efecto adverso en la salud de las comunidades a lo largo del río, que dependen de la salud del río mismo. Adicionalmente, en consideración de Nicaragua, la carretera afectó significativamente el área de turismo potencial, ya que ha tenido efectos visuales negativos en el paisaje natural. Finalmente, Nicaragua argumenta que, además del daño transfronterizo que la carretera ya ha causado, genera un riesgo significativo de daño trasfronterizo en el futuro. De acuerdo con Nicaragua, los riesgos adicionales derivan de la posibilidad de derrames de materiales tóxicos en el río cuando las sustancias peligrosas sean transportadas por la carretera, así como de cualquier otro desarrollo en el banco derecho del río, como, por ejemplo, un incremento en las actividades agrícolas y comerciales.

215. Costa Rica responde que Nicaragua no ha aducido ninguna evidencia del impacto efectivo en el turismo o en la salud de las comunidades ribereñas. Adicionalmente, no explicó la base legal de su reclamación. Además, Costa Rica alega que el argumento de Nicaragua sobre el riesgo de derrames tóxicos en el río está basado por completo en la especulación: la Regulación de Costa Rica de 1995 para el Transporte Terrestre de Materiales Peligrosos prevé que las sustancias peligrosas solo pueden ser transportadas en rutas autorizadas, y la ruta 1856 no es una de ellas. 
216. La Corte encuentra que Nicaragua no ha confirmado su alegato en relación con el daño al turismo y la salud. La Corte también observa que los argumentos de Nicaragua en relación con el riesgo de derrames tóxicos en el río y de futuros trabajos de Costa Rica en el banco del río son especulativos y no demuestran ningún daño. Por lo tanto, estos argumentos son defectuosos.

\section{c) Conclusión}

217. A la luz de lo anterior, la Corte concluye que Nicaragua no ha probado que la construcción de la carretera le causó un daño transfronterizo significativo. Por lo tanto, la pretensión de Nicaragua, según la cual Costa Rica violó su obligación sustancial bajo el derecho internacional consuetudinario en relación con el daño transfronterizo, debe ser rechazada.

\section{Presuntas violaciones de las obligaciones convencionales}

218. Nicaragua también alega que Costa Rica violó sus obligaciones sustanciales contenidas en varios instrumentos universales y regionales. Primero, arguye que Costa Rica violó el artículo 3, párrafo 1, de la Convención de Ramsar. Segundo, argumenta que Costa Rica actuó de manera contraria al objeto y propósito del Acuerdo de 1990 sobre Áreas Protegidas de Frontera entre Nicaragua y Costa Rica (Acuerdo SI-A-PAZ). Tercero, Nicaragua sostiene que, con sus actividades, Costa Rica violó los artículos $3^{\circ}$ y $8^{\circ}$ del Convenio sobre la Diversidad Biológica. Cuarto, reclama que Costa Rica violó varias disposiciones del Convenio para la Conservación de la Biodiversidad y Protección de Áreas Silvestres Prioritarias en América Central. Quinto, alega violaciones del Convenio Centroamericano para la Protección del Ambiente y del Protocolo de Tegucigalpa a la Carta de la Organización de Estados Americanos. Finalmente, Nicaragua sostiene que Costa Rica violó el artículo $3^{\circ}$ del Acuerdo Regional sobre el Movimiento Transfronterizo de Desechos Peligrosos, debido a que no adoptó ni implementó un enfoque de precaución frente a los problemas de polución derivados de ese instrumento.

219. En respuesta a estas alegaciones, Costa Rica señala, desde el principio, que Nicaragua desde el principio que Nicaragua no demostró que la construcción de la carretera causó ningún daño transfronterizo significativo, razón por la cual su alegato es fallido. Costa Rica además indica que la construcción de la carretera no afecta los humedales protegidos de Nicaragua conforme a la Convención de Ramsar. Además, precisa que 
Nicaragua no ha identificado ninguna disposición del Acuerdo SI-A-PAZ que hubiera sido presuntamente violada. Costa Rica también sostiene que el Convenio Centroamericano para la Protección del Ambiente y el Protocolo de Tegucigalpa no son de relevancia en la actual disputa y que no existe base fáctica para el alegato de Nicaragua en relación con el Acuerdo Regional sobre el Movimiento Transfronterizo de Desechos Peligrosos.

220. La Corte observa que tanto Nicaragua como Costa Rica son partes de los instrumentos invocados por Nicaragua. Con independencia de la cuestión sobre el carácter vinculante de algunos de las disposiciones en discusión, la Corte señala que, en relación con estos instrumentos, Nicaragua simplemente hace manifestaciones sobre las presuntas violaciones por parte de Costa Rica, pero no explica cómo los "objetivos" de los instrumentos o sus disposiciones habrían sido violados, especialmente, en ausencia de prueba de daño ambiental significativo (ver párrafo 217 arriba). Por lo tanto, la Corte considera que Nicaragua no ha demostrado que Costa Rica infringió los instrumentos anteriormente mencionados.

\section{La obligación de respetar la integridad territorial de Nicaragua y su soberanía sobre el río San Juan}

221. Nicaragua también alega que los deltas creados por el sedimento erosionado de la carretera constituyen "invasiones físicas, incursiones por parte de Costa Rica en el territorio soberano de Nicaragua... a través de la agencia del sedimento", y la presencia de estos constituye una "invasión" dentro del territorio de Nicaragua. Además, Nicaragua sostiene que el vertimiento de sedimentos, tierra, vegetación y árboles talados al río por parte de Costa Rica genera una amenaza seria al ejercicio del derecho de navegación de Costa Rica en el río San Juan, que se basa en su derecho soberano en el río. Por lo tanto, Nicaragua reclama que, en razón de su conducta y actividades, Costa Rica violó la integridad territorial de Nicaragua y su soberanía sobre el río San Juan, según se estableció en el Tratado de 1858.

222. Costa Rica señala que llevar a cabo trabajos de infraestructura vial por completo dentro de su territorio no infringe la frontera delimitada por el Tratado de 1858 ni viola la soberanía de Nicaragua, tampoco afecta el derecho de Nicaragua a navegar el río San Juan. Adicionalmente, Costa Rica sostiene que el Tratado de 1858 no tiene ningún efecto en este caso, ya que no regula las cuestiones que están en juego aquí. 
223. La Corte considera que, ya sea que se creen deltas de sedimentos como consecuencia de la construcción de la carretera, la teoría de Nicaragua para apoyar su pretensión de una violación de su integridad territorial a través del sedimento no es convincente. No existe evidencia de que Costa Rica ejerciera ninguna autoridad en el territorio de Nicaragua o que haya llevado a cabo ninguna actividad allí. Adicionalmente, por las razones ya expresadas en los párrafos 203 a 207 arriba, Nicaragua no ha demostrado que la construcción de la carretera hubiera afectado sus derechos de navegación en el río San Juan. Por lo tanto, la pretensión de Nicaragua frente a la violación de su integridad territorial y soberanía debe ser rechazada.

\section{Reparación}

224. Nicaragua le solicita a la Corte que juzgue y declare que, con su conducta, Costa Rica ha violado su obligación de no violar la integridad territorial de Nicaragua, su obligación de no dañar el territorio de Nicaragua y sus obligaciones bajo el derecho internacional general y los tratados ambientales (pretensiones finales, para. 1; ver párrafo 52 arriba).

A la luz del razonamiento anterior, la declaración de la Corte sobre la violación por parte de Costa Rica de su obligación de llevar a cabo un estudio de impacto ambiental es la forma apropiada de satisfacción para Nicaragua.

225. En segundo lugar, Nicaragua le pide a la Corte ordenar a Costa Rica "[c]esar todos los hechos internacionalmente ilícitos de carácter continuado que afectan o tienen la probabilidad de afectar los derechos de Nicaragua" —ibíd., para. 2(i)—.

La Corte considera que el hecho de que Costa Rica no haya llevado a cabo un estudio de impacto ambiental actualmente no afecta adversamente los derechos de Nicaragua ni tiene la probabilidad de afectarlos ulteriormente. En consecuencia, no existen fundamentos para otorgar la reparación solicitada.

226. En tercer lugar, Nicaragua le pide a la Corte ordenar a Costa Rica restaurar en la medida de lo posible la situación que existía antes de que la carretera fuera construida y que le proporcione una compensación por el daño causado en la medida en que no se logre la reparación a través de la restitución —ibíd., para. 2(ii) y (iii)—.

La Corte recuerda que la restitución y la compensación son formas de reparación con el daño material. La Corte observa que, aunque Costa Rica no cumplió con la obligación de llevar a cabo un estudio de impacto 
ambiental, no se ha establecido que la construcción de la carretera causó un daño significativo a Nicaragua o violó otras obligaciones sustanciales bajo el derecho internacional. Como tal, restaurar la condición original del área en donde la carretera se localiza no constituiría el remedio apropiado frente a la violación de Costa Rica de su obligación de realizar un estudio de impacto ambiental — ver Plantas de celulosa en el río Uruguay (Argentina c. Uruguay), ICJ Reports 2010, (I), p. 104, para. 271). Por las mismas razones, la Corte declina otorgar la solicitud de compensación de Nicaragua.

En vista de que Nicaragua no aportó prueba de que se hubiera causado un daño significativo, la Corte no encuentra necesidad de considerar la designación de un experto o de un comité para evaluar la extensión del daño y la cadena de causación, como lo sugirió Nicaragua.

227. La Corte también considera que la solicitud de Nicaragua para que se ordene a Costa Rica no llevar a cabo desarrollos futuros en el área de frontera sin el estudio de impacto ambiental apropiado — pretensión final, para. 3(i) — debe ser rechazada. Como la Corte lo expresó en el párrafo 173 arriba, la obligación de Costa Rica de efectuar un estudio de impacto ambiental solo aplica a las actividades que implican un riesgo de daño transfronterizo significativo, y no existe razón para suponer que Costa Rica no cumplirá con sus obligaciones bajo el derecho internacional, como se describieron en este fallo, en la conducción de nuevas actividades en el área, incluyendo trabajados de construcción adicionales en la carretera.

228. Para concluir, la Corte observa que Costa Rica ha iniciado trabajos de mitigación para reducir los efectos adversos de la construcción de la carretera en el medio ambiente. Espera que Costa Rica continúe avanzando en estos esfuerzos en cumplimiento de su obligación de debida diligencia en el monitoreo de los efectos del proyecto en el medio ambiente. También reitera el valor de una cooperación continuada entre las partes en el cumplimiento de sus respectivas obligaciones en relación con el río San Juan.

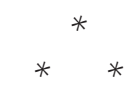

229. Por estas razones,

LA CORTE

1) Por catorce votos contra dos, 
Determina que Costa Rica tiene soberanía sobre el "territorio en disputa”, según fue definido por la Corte en los párrafos 69-70 del presente fallo.

A FAVOR: presidente Abraham; vicepresidente Yusuf; jueces Owada, Tomka, Bennouna, Cançado Trindade, Greenwood, Xue, Donoghue, Gaja, Sebutinde, Bhandari, Robinson; juez ad hoc Dugard.

EN CONTRA: juez Gevorgian, juez ad hoc Guillaume.

2) Unánimemente,

Determina que, al excavar los tres caños y establecer presencia militar en territorio de Costa Rica, Nicaragua ha violado la soberanía territorial de Costa Rica,

3) Unánimemente,

Determina que, al excavar los tres caños y establecer en 2013 presencia militar en el territorio en disputa, Nicaragua ha violado sus obligaciones bajo la orden de medidas provisionales emitida por la Corte el 8 de marzo de 2011.

4) Unánimemente,

Determina que, por las razones expuestas en los párrafos 135-136 del presente fallo, Nicaragua ha violado los derechos de Costa Rica a la navegación del río San Juan de conformidad con el Tratado de Límites de 1858.

5)

(a) Unánimemente,

Determina que Nicaragua tiene la obligación de compensar a Costa Rica por los daños materiales causados por las actividades ilegales de $\mathrm{Ni}$ caragua en el territorio de Costa Rica.

(b) Unánimemente,

Decide que, en ausencia de acuerdo entre las partes sobre este aspecto dentro de los doce meses siguientes a la fecha de este fallo, la cuestión de la compensación debida a Costa Rica deberá, a solicitud de una de las partes, ser resuelta por la Corte, y reserva para estos propósitos el siguiente procedimiento en el caso relativo a Ciertas actividades llevadas a cabo por Nicaragua en el área de frontera (Costa Rica c. Nicaragua).

(c) Por doce votos contra cuatro,

Rechaza la solicitud de Costa Rica para que se ordene a Nicaragua pagar las costas incurridas en los procedimientos. 
A FAVOR: presidente Abraham; vicepresidente Yusuf; jueces Owada, Bennouna, Cançado Trindade, Xue, Donoghue, Gaja, Sebutinde, Bhandari, Robinson, Gevorgian; juezad hoc Guillaume.

EN CONTRA:juez Tomka, Greenwood, Sebutinde; juezad hoc Dugard.

6) Unánimemente,

Determina que Costa Rica ha violado su obligación bajo el derecho internacional general al no llevar a cabo un estudio de impacto ambiental en relación con la construcción de la ruta 1856 .

7) Por trece votos contra tres,

Rechaza todas las otras pretensiones hechas por las partes.

A FAVOR: presidente Abraham; vicepresidente Yusuf; jueces Owada, Bennouna, Cançado Trindade, Xue, Donoghue, Gaja, Sebutinde; juez ad hoc Guillaume.

EN CONTRA: jueces Bhandari, Robinson; juezad hoc Dugard. 



\section{Opiniones separadas de los jueces}

\section{Declaración del vicepresidente Yusuf}

Aunque en acuerdo con las cláusulas operativas del fallo, el juez Yusuf indica que ambas partes alegaron que su integridad territorial había sido violada por las acciones de la otra. El razonamiento de la Corte, en su consideración, abordó de forma inadecuada esas pretensiones.

La inviolabilidad de las fronteras es una parte fundamental de la integridad territorial. Una intrusión dentro del territorio de un Estado, tan pequeña como pueda ser, viola la inviolabilidad de un Estado, norma consagrada en la Carta de la Organización de Estados Americanos, la Carta de las Naciones Unidas y el derecho internacional consuetudinario. La violación de este principio está necesariamente vinculada con la violación de la prohibición de la amenaza o uso de la fuerza por parte de la parte invasora, como es evidente a partir de la Declaración sobre los Principios de Derecho Internacional Referentes a las Relaciones de Amistad y a la Cooperación entre los Estados de conformidad con la Carta de las Naciones Unidas.

Así mismo, en su jurisprudencia previa, la Corte ha enfatizado el rol crucial que la integridad territorial juega en la comunidad internacional. $\mathrm{Al}$ no reiterar y enfatizar la importancia de este principio, el presente fallo es inconsistente con la jurisprudencia previa de la Corte.

\section{Opinión separada del juez Owada}

Aunque el juez Owada votó a favor de las conclusiones de la Corte en la parte operativa del fallo, en su opinión separada él desea elaborar su posición en aquellos aspectos del razonamiento de la Corte que considera no fueron desarrollados con suficiente claridad en el fallo. 


\section{La cuestión de la soberanía sobre el territorio en disputa}

El juez Owada observa que la Corte correctamente concluyó que los instrumentos legales relevantes para determinar la soberanía sobre el "territorio en disputa" deben ser el Tratado de 1858, el laudo Cleveland de 1888 y el laudo Alexander de 1897 (fallo, párrafo 76). Sin embargo, el juez Owada encuentra que el fallo no ha sido lo suficientemente articulado en la secuencia lógica que existe entre esos instrumentos legales. En la posición del juez Owada, lo que es decisivo para los propósitos de establecer la soberanía sobre el territorio en disputa es, en primer lugar, y ante todo, la interpretación de los instrumentos legales relevantes a la luz de los roles que les fueron asignados, sus propósitos y contextos.

El juez Owada enfatiza que bajo estas circunstancias la tarea de la Corte no ha sido ni podía ser la de identificar la ubicación geográfica del "primer punto de encuentro del canal" o la de seguir la línea descrita en el primer laudo Alexander de 1897. El juez Owada considera que la respuesta de la Corte a la cuestión de la soberanía territorial sobre el territorio en disputa debe estar basada en las mismas fuentes legales y en el mismo razonamiento legal que el general Alexander aplicó en la implementación del laudo Cleveland de 1888, el cual previó la interpretación y determinación autorizada y vinculante de la frontera prescrita por el Tratado de 1858.

El juez Owada indica que el general Alexander estaba tratando, en su primer laudo, de seguir fielmente la precepción contenida en el artículo II del Tratado de 1858. Como el juez Owada también lo observó y discutió en detalle, el resultado inequívoco que la Corte ha alcanzado en el presente fallo sobre la cuestión de la soberanía en los territorios en disputa está confirmado por la aplicación del razonamiento subyacente en el primer y segundo laudo Alexander a la actual situación geográfica del área en disputa.

El juez Owada recuerda que las partes en el presente caso le han proporcionado a la Corte un número de argumentos y han aportado una variedad de material probatorio de apoyo, todos relacionados con la cuestión de si alguno de los canales navegables ha atravesado o actualmente atraviesan el territorio en disputa. El juez Owada concurre con la evaluación que la Corte hizo de la evidencia, aunque enfatiza su propia conclusión en el sentido de que, de la totalidad de esa evidencia, es realmente poca la que llega a ser materia o conclusiva para la decisión de la cuestión de la soberanía territorial sobre el territorio en disputa. 


\section{Consecuencias legales de la determinación de la Corte en relación con la soberanía en el territorio en disputa}

El juez Owada da inicio a esta parte de su opinión separada distinguiendo la situación del presente caso de la disputa territorial que típicamente se lleva ante la Corte Internacional de Justicia, después de que las partes han intentado resolver pacíficamente el asunto. El juez Owada subraya que en el presente caso, como está implícito en el lenguaje del fallo mismo, la disputa territorial ha sido causada de forma primaria por acciones unilaterales adoptadas en la forma de incursiones física de un Estado en el territorio del otro, territorio que de forma principal ha sido resguardado por varios años por el último.

En opinión del juez Owada, a la luz de este hecho indiscutido, hubiera resultado apropiado que la Corte hubiera tratado los actos relevantes de Nicaragua como un claro y directo hecho internacionalmente ilícito que podría equivaler a un uso ilícito de la fuerza bajo el artículo 2(4) de la Carta de las Naciones Unidas. El juez Owada anota que, aunque él ha concurrido con las conclusiones de la Corte en este punto, hubiera sido más apropiado para la Corte haber ido más lejos y declarar que estos hechos internacionalmente ilícitos de las autoridades de Nicaragua constituyeron un uso ilegal de la fuerza bajo el artículo 2(4) de la Carta de las Naciones Unidas.

El juez Owada también observa que la referencia del fallo en este contexto al caso de Camerún c. Nigeria parece inapropiada y puede ser bastante engañosa. De acuerdo con el juez Owada, ese caso debe ser claramente distinguido de la presente situación, en la medida en que el caso de Camerún c. Nigeria no fue causado por una acción de una parte para alterar el statu quo existente a través de acciones unilaterales.

\section{La naturaleza del requisito de llevar a cabo un estudio de impacto ambiental}

El juez Owada comenzó esta parte de su opinión separada observando que, en el proceso de cumplir con la obligación de actuar en debida diligencia bajo el derecho internacional ambiental, el requisito de llevar a cabo un estudio de impacto ambiental constituye un elemento clave para determinar si ciertas actividades podrían causar un daño transfronterizo 
significativo. El juez Owada recuerda que en este contexto ambas partes se refirieron con aprobación al dictum de la Corte en el fallo del caso sobre las plantas de celulosa en el río Uruguay (Argentina c. Uruguay), donde la Corte ha referido que el estudio de impacto ambiental es una "práctica que en años recientes ha ganado tanta aceptación entre los Estados que puede considerarse ahora un requisito bajo el derecho internacional general" —ICJ Reports 2010, (I), p. 83, para. 204-.

El juez Owada observa que este dictum de la Corte debe considerarse en contraste con la determinación del Tribunal Internacional sobre el Derecho del Mar en su opinión consultiva sobre la responsabilidad y obligaciones de los Estados con respecto a las actividades en la zona, según la cual el estudio de impacto ambiental como tal "es una obligación general bajo el derecho internacional consuetudinario" —ITLOS Reports 2011, para. 145- El juez Owada considera que, en comparación, el razonamiento de la Corte en el fallo en plantas de celulosa parece tomar un enfoque más matizado frente a este requisito. En opinión del juez Owada, en su fallo en el caso de las plantas de celulosa enfatizó la importancia del estudio de impacto ambiental en el contexto del proceso de cumplir con la obligación de debida diligencia, el cual es un proceso holístico. El juez Owada observa que llevar a cabo un estudio de impacto ambiental es un elemento constitutivo importante del proceso que emana de la obligación internacional de los Estados de actuar con la debida diligencia para evitar o mitigar el impacto transfronterizo significativo, más que una obligación de existencia independiente y separada bajo el derecho internacional general.

En la posición del juez Owada, este enfoque balanceado ha sido preservado en el presente fallo y se refleja en la parte de este que se ocupa del "requisito de llevar a cabo un estudio de impacto ambiental" (fallo, párrafo 104). El juez Owada recuerda que la conclusión de la Corte en la parte operativa del fallo — párrafo 229(6) — está basada en este razonamiento. Finalmente, el juez Owada enfatiza que el estudio de impacto ambiental, que es esencialmente de naturaleza técnica, es una de las formas posibles para alcanzar el objetivo legal final vinculante para los Estados que interactúan en el escenario ambiental —una obligación de actuar con la debida diligencia para prevenir el daño trasfronterizo significativo a la luz de los riesgos involucrados analizados-. 


\section{Declaración conjunta de los jueces Tomka, Greenwood y Sebutinde y del juez 'ad hoc' Dugard}

Los jueces Tomka, Greenwood y Sebutinde y el juez ad hoc Dugard consideran que la Corte debió haber ordenado a Nicaragua pagar las costas en las que Costa Rica incurrió para obtener una segunda orden de medidas provisionales en 2013. Ellos recuerdan que el artículo 64 del Estatuto de la Corte, junto con el artículo 97 de las reglas de la Corte, le otorga a la Corte la discrecionalidad para otorgar costas. Ellos observan que las costas incurridas por Costa Rica fueron una consecuencia de las serias violaciones por parte de Nicaragua de sus obligaciones bajo la orden de 2011 sobre medidas provisionales. Ellos indican que Nicaragua pudo haber adoptado acciones que hubieran hecho innecesarias las audiencias de octubre de 2013, pero no lo hizo. Aunque Costa Rica podrá obtener compensación por los daños derivados de la violación de la orden de 2011, no podrá recuperar los gastos de casi una semana de audiencias. Los jueces Tomka, Greenwood y Sebutinde y el juez ad hoc Dugard consideran que es ilógico que un Estado que viola una orden de medidas provisionales sea tratado de manera menos favorable cuando busca rectificación ante la Corte que cuando ha adoptado medidas unilaterales de remediación. Los jueces opinan que, aunque el poder de otorgar costas bajo el artículo 64 nunca ha sido usado, las circunstancias excepcionales de este caso le ordenan a la Corte ejercer ese poder y, por ende, otorgar costas a Costa Rica.

\section{Opinión separada del juez Cançado Trindade}

1. En su opinión separada, compuesta de doce partes, el juez Cançado Trindade destaca, primeramente, que, aunque se alinea con la mayoría en la presente sentencia de la Corte Internacional de Justicia (CI) del 16.12.2015, en los casos acumulados “Ciertas actividades llevadas a cabo por Nicaragua en la zona fronteriza (Costa Rica c. Nicaragua)" y "Construcción de una carretera en Costa Rica a lo largo del río San Juan (Nicaragua c. Costa Rica)", él encuentra que hay ciertos puntos involucrados en ellos, que no fueron tratados a profundidad por la Corte en su razonamiento, que en su opinión merecen de mayor importancia, requerida al adecuado ejercicio de la función judicial internacional. Por ello, se siente obligado a volver sobre ellos, en la presente opinión 
separada, alimentando la esperanza de que sean útiles para la resolución de estos asuntos en casos futuros de la CIJ.

2. El juez Cançado Trindade comienza señalando (parte I) los puntos que tiene en mente, siendo estos: a) las manifestaciones de la prevención en el derecho internacional contemporáneo; b) La evolución y conformación de un régimen autónomo de medidas provisionales de protección; c) medidas provisionales y el crecimiento del ámbito de la protección; d) la violación de medidas provisionales de protección como una violación autónoma, resultante en responsabilidad internacional por sí misma; e) la determinación de la CIJ de violación de obligaciones bajo medidas provisionales de protección. Seguidamente, presenta sus reflexiones, en forma de una súplica, para una pronta determinación de las violaciones sobre las medidas provisionales de protección.

3. El juez Cançado Trindade luego procede a examinar los siguientes puntos: a) supervisión del cumplimiento de medidas provisionales de protección; b) incumplimiento de las medidas provisionales y reparación de daños; c) debida diligencia y la correlación entre el principio de prevención y el principio de precaución; d) el camino hacia un desarrollo progresivo de las medidas provisionales de protección como una violación autónoma, resultante en responsabilidad internacional del Estado por sí misma. Con esto se prepara el camino para la presentación, en un epílogo, de una recapitulación de sus conclusiones sobre tales puntos.

4. Respecto al primero de los puntos mencionados, principalmente las manifestaciones de la dimensión preventiva en el derecho internacional contemporáneo (parte II), el juez Cançado Trindade observa que los presentes casos acumulados "Ciertas actividades llevadas a cabo por Nicaragua en la zona fronteriza (Costa Rica c. Nicaragua)" " "Construcción de una carretera en Costa Rica a lo largo del río San Juan (Nicaragua c. Costa Rica)" llaman la atención sobre la relevancia de la dimensión preventiva, como se refleja en la presente sentencia, en la búsqueda de consecuencias legales a la violación de medidas provisionales de protección (en el caso de "Ciertas actividades llevadas a cabo por Nicaragua"), como también al reconocimiento de la obligación de conducir un estudio de impacto ambiental (en el caso "Construcción 
de una carretera"). Esta dimensión preventiva crece en importancia en el marco de regímenes de protección (como, por ejemplo, de la persona humana y el medio ambiente). Más aún, nos lleva particularmente cerca a principios generales de derecho (para. 4).

5. Tal dimensión preventiva es relevante en la sucesión de órdenes de la Corte sobre medidas provisionales de protección del 8.3.2011, 16.7.2013 y 22.11.2013, y ha sido reseñado por las partes en el curso de los procedimientos (fases orales y escritas) ante la Corte (también en la etapa de méritos). La Corte ha debidamente considerado las solicitudes de las partes y ha encontrado que el Estado demandado incurrió (en el caso "Ciertas actividades") en la violación de obligaciones bajo la orden de medidas provisionales de protección del 8.3.2011, al excavar dos caños en 2013 y el establecimiento de presencia militar en el territorio en disputa (paras. 127 y 129, punto resolutorio 3 del dispositif).

6. El juez Cançado Trindade recuerda que ya por algún tiempo ha estado llamando la atención de la Corte hacia la existencia de un régimen legal autónomo de medidas provisionales de protección, en el que él concibe y ha conceptualizado a lo largo de los años tal régimen legal autónomo, en una sucesión de opiniones separadas y declaraciones en esta Corte (parte III). La presente sentencia de la Corte en los casos acumulados "Ciertas actividades" y "Construcción de una carretera" es otra de esas ocasiones, y una muy apropiada, para profundizar sobre ello. Para iniciar, ese régimen legal puede ser mejor apreciado si consideramos las medidas provisionales desde su evolución histórica. Permítase recordar que, en sus orígenes, en la doctrina del derecho procesal interno, por más de un siglo, las medidas provisionales fueron consideradas, y evolucionaron, en orden de salvaguardar la efectividad de la función judicial misma (para. 7).

7. Por lo tanto, emergieron — continúa - en los sistemas legales domésticos, en forma de una acción legal de precaución (mesure conservatoire/acción cautelar/ação cautelar), apuntando a garantizar, no directamente derechos subjetivos per se, sino el proceso jurisdiccional mismo. Ellas "aún no se han liberado de cierto formalismo jurídico, dando la impresión de tomar el 
proceso judicial como un fin en sí mismo, más que un medio para la realización de la justicia" (para. 8). Con su transposición al procedimiento legal internacional, y el crecimiento de su uso recurrente dentro de marcos de protección (por ejemplo, la persona humana o el medio ambiente), se han convertido en recurrentemente requeridas, frente a las más diversas circunstancias, ante la probabilidad o inminencia de un daño irreparable, que se debe prevenir o evitar. Esto tiene el efecto, en su percepción, de aumentar el ámbito de la jurisdicción internacional, y refinar su conceptualización (para. 9).

8. Con su considerable expansión a lo largo de las últimas tres décadas, es claro para las partes en litigio que debían abstenerse de cualquier acción que pueda agravar la disputa pendente lite, o pueda tener un efecto perjudicial en el cumplimiento del fallo subsecuente en cuanto al fondo. Su racionalidad se hizo aún más clara al girar hacia la protección de derechos, la igualdad de armas (égalité des armes), y no solo la legalidad del proceso. Ellas

se han liberado del formalismo jurídico de la doctrina procesal de más de un siglo atrás, y han, en mi percepción, llegado más cerca de obtener su plenitud. Han sido dotadas de un carácter de precaución, verdaderamente cautelar. Cuando sus requisitos básicos — gravedad y urgencia, y la necesidad de prevención de un daño irreparable — se cumplen, han sido ordenadas, a la luz de la necesidad de protección y han conformado una verdadera garantía judicial de carácter preventivo (para. 10).

9. Un tribunal internacional como la CIJ tiene el poder inherente o faculté de determinar el ámbito de las medidas provisionales que decida ordenar, lo que refuerza la dimensión preventiva propia de tales medidas (paras. 11, 36, 62). Tal poder inherente se ejerce en orden de asegurar la debida administración de justicia (la bonne administration de la justice) (paras. 12 y 63). El régimen legal autónomo de medidas provisional incluye, según el juez Cançado Trindade (ya explicado en sus previas opinión disidente y opinión separada en la CIJ, paras. 14-16 y 21-23), su naturaleza jurídica, los derechos y obligaciones que implica 
al ser proferida, sus efectos legales y el deber de cumplirlas (para. 13).

10. Las medidas provisionales se han expandido, y en la práctica han ampliado el ámbito de protección (parte IV, paras. 17-18). Para el juez Cançado Trindade, no es "casual" que sean concebidas como medidas de precaución (mesures provisoires/medidas cautelares), prevención y precaución implícitas en todas ellas, y agrega:

Precaución, en efecto, lleva más lejos a la prevención, frente a la incertidumbre de los riesgos, para evitar daños irreparables. Y aquí, de nuevo, en el dominio de las medidas provisionales de protección, la relación entre el derecho internacional y el tiempo se hace manifiesta. La dimensión intertemporal se hace aquí ineludible, superando las barreras del positivismo jurídico. El derecho internacional involucra ser anticipatorio en la regulación de hechos sociales, como en evitar el daño irreparable: las medidas provisionales expanden la protección que persiguen, como una verdadera garantía judicial internacional de carácter preventivo (para. 19).

11. El juez Cançado Trindade luego gira hacia la violación de medidas provisionales de protección, que considera como una violación autónoma, que deriva en responsabilidad internacional del Estado por sí misma (parte V), y adicional a la violación que viene, o puede venir, a ser determinada posteriormente en la decisión de fondo del caso (para. 24). Según esto, la violación de medidas provisionales puede, en su entendimiento, ser prontamente determinada, con sus consecuencias legales, sin necesidad de esperar a la conclusión de los procedimientos de fondo (para. 25).

12. El juez Cançado Trindade después revisa las sentencias de la CIJ sobre la determinación de violaciones a obligaciones bajo medidas provisionales de protección (parte VI), donde la Corte lo ha hecho al final del procedimiento de fondo en los correspondientes casos, siendo estos, además del caso presente, en las sentencias de fondo en LaGrand (2001), Actividades armadas en el territorio del Congo (2005) y Genocidio en Bosnia (2007). En el temprano caso de Rehenes en Teherán (Estados Unidos $c$. Irán) (sentencia del 24.05.1980), la CIJ no afirmó expresamente 
que la orden de medidas provisionales del 15.12.1979 había sido violada.

13. Encontró tal violación (de su orden de medidas provisionales del 3.3.1999) en el caso LaGrand (Alemania c. Estados Unidos) (sentencia del 27.6.2011), pero sin derivar ninguna consecuencia de la conducta violatoria de medidas provisionales. Cuatro años después, en su sentencia del 19.12.2005 en el caso concerniente a Actividades armadas en el territorio del Congo (R. D. Congo c. Uganda), la CIJ, al referirse a su orden de medidas provisionales 1.7.2000 adoptada media década antes - concerniente a las violaciones del derecho internacional humanitario y el derecho internacional de los derechos humanos-, encontró que el Estado demandado no había cumplido con ella, y reiteró sus hallazgos en el punto resolutorio 7 del dispositif.

14. Otro caso de determinación por la CIJ de violación de sus órdenes de medidas provisionales de protección fue el de Aplicación de la Convención contra el Genocidio (Bosnia Herzegovina c. Serbia y Montenegro): la Corte lo sostuvo en su sentencia del 26.02.2007, mientras que las órdenes de medidas provisionales habían sido adoptadas catorce años antes, en 8.4.1993 y 13.9.1993, buscando el cese de atrocidades que ya se estaban perpetrando. Dos años después de su primera orden 8.4.1993, el área segura de la ONU en Srebrenica colapsó y los asesinatos en masa de julio de 1995 en Srebrenica ocurrieron en una flagrante violación de las medidas provisionales ordenadas por la CIJ (paras. 30-31).

15. Mientras tanto, los procedimientos en el caso ante la CIJ se prolongaron en el tiempo: las objeciones preliminares hasta 1996, las pretensiones reconvencionales en 1997, de nuevo en 2001 y la etapa de fondo hasta 2007. Las manifiestas violaciones de las órdenes de medidas provisionales de protección de 1993 pasaron largo tiempo sin determinación, y sin consecuencia legal. Tomó catorce años para la Corte determinar, en su sentencia de fondo (2007), la violación de sus medidas provisionales de protección en el cas d'espèce. Para el juez:

No había necesidad de esperar tan largo tiempo para determinar la violación de tales medidas, por el contrario, debió ser prontamente determinada por la CIJ, con todas sus consecuencias legales. Este trágico caso muestra que aún estamos en la infancia del desarrollo de un 
régimen legal de medidas provisional en el derecho internacional contemporáneo. Una adecuada comprensión del régimen legal autónomo de esas medidas puede promover su desarrollo conceptual (para. 33).

16. En sus posteriores reflexiones, como un llamado a la pronta determinación de violaciones a medidas provisionales de protección (parte VII), el juez Cançado Trindade pondera, primero, que, en el cas d'espèce ("Ciertas actividades"), las violaciones de medidas provisionales fue determinada por la Corte dentro de un lapso razonable — distinto al caso de Actividades armadas en territorio del Congo (media década después), y en el caso Genocidio en Bosnia (casi década y media después)—. En el cas d'espèce, los daños causados por las violaciones de medidas provisionales no fueron irreparables — como sí en el caso LaGrand-y "con su determinación la Corte en la presente sentencia, puede hacer que cesen sus efectos" (para. 34).

17. En efecto, a su entender, "la determinación de la violación de una medida provisional de protección no es, ni debe ser, condicionada por la finalización de los procedimientos subsecuentes de fondo en el caso" (para. 35). Los efectos legales de la violación de medidas provisionales de protección deben, en su opinión, "ser determinados prontamente, con todas sus consecuencias legales, de esta manera, se sirve mejor a su racionalidad anticipatoria". En su opinión, "no hay lugar a alegar las presuntas dificultades de evidencia"; tanto para ordenar las medidas provisionales de protección como en la determinación de su incumplimiento, "es suficiente contar con evidencia prima facie (commencement de prewve)" (para. 35).

18. Adicionalmente, los derechos que se busca proteger con las medidas provisionales "no son necesariamente los mismos a vindicar en el fondo", como lo demuestra el caso del Templo de Préah Vihear. A su vez, "las obligaciones de prevención son nuevas o adicionales, en relación con aquellas que se derivan de la sentencia de fondo" (para. 36). El hecho de que, en su práctica, la CIJ haya solo indicado medidas provisionales a solicitud de un Estado parte "no significa que no pueda ordenarlas sponte sua, ex officio" (para. 37). El Estatuto de la CIJ le da a la Corte el poder para hacerlo, si considera que las circunstancias lo requieren —artículo 41(1) - 
19. Las reglas de la Corte indican que, independiente de la solicitud de una parte, la Corte puede indicar medidas provisionales que, en su opinión, "sean en todo o en parte diferentes a las solicitadas" —artículo 75(2)—. Esto ocurrió en el caso concerniente a la Delimitación territorial y marítima entre Camerín y Nigeria (orden del 15.03.1996) y Actividades armadas en el territorio del Congo ( $\mathrm{R}$. D. Congo c. Uganda) (orden del 1.7.2000). El juez Cançado Trindade agrega que "la Corte no está condicionada por lo que una parte, o las partes, solicite, tampoco —en mi opinión- por la existencia misma de la solicitud. Aquí, en el ámbito de las medidas provisionales de protección, una vez más las barreras del positivismo legal y voluntarista deben ser, en mi opinión, superadas".

20. Posteriormente, apunta que recientemente ha habido casos ante la Corte donde se le ha solicitado que "razone más allá de la dimensión interestatal, al no limitarse a las solicitudes e intereses de las partes en litigio", como lo señala en su opinión separada (paras. 227-228) en el caso de A. S. Diallo (Guinea c. R. D. Congo) (sentencia de fondo 30.11.2010) y en su opinión disidente en el caso Cuestiones relativas a la obligación de juzgar y extraditar (Bélgica c. Senegal) (orden de medidas provisionales del 28.5.2009), como también en su opinión disidente en el caso concerniente a la Aplicación de la Convención Internacional para la Eliminación de Todas las Formas de Discriminación (Georgia c. Federación Rusa) (sentencia de excepciones preliminares del 1.4.2011) (paras. 40-41). El juez Cançado Trindade advierte que la Corte:

no es un tribunal arbitral, y se eleva por encima de la voluntad de las partes en contienda. No está condicionada por las solicitudes o intenciones profesadas por las partes. Tiene el poder inherente o faculté para proceder prontamente a la determinación de la violación de medidas provisionales, en el interés de la debida administración de justicia. Y la recta ratio es la que guía la correcta administración de justicia, por ello, la recta ratio debe sobreponerse a la voluntad (del Estado). Esta guía da adjudicación internacional y asegura obligatoriedad y supremacía del derecho (prééminence du droit) en el ámbito internacional.

La Corte es enteramente libre de ordenar medidas provisionales que considere necesarias, para prevenir que la disputa se agrave o la 
ocurrencia de daño irreparable, incluso si las medidas que decide ordenar son distintas a aquellas solicitadas por las partes en contienda (paras. 42-43).

21. El juez Cançado Trindade concluye, en este asunto particular, que la CIJ puede, tras examinar las circunstancias del cas d'espèce, proceder a ordenar, sponte sua, medidas provisionales de protección. Puede hacerlo motu proprio, para evitar que se agrave la situación. Esta determinación ex officio de la ocurrencia de la violación de una orden de medidas provisionales de protección mantiene la dimensión preventiva en el derecho internacional contemporáneo, evitando daño irreparable. En su opinión, "la Corte no tiene que esperar hasta que se completen los procedimientos respecto al fondo, especialmente si esos procedimientos son irrazonablemente prolongados, como en el caso del genocidio en Bosnia” (para. 44).

22. El juez Cançado Trindade continúa con el asunto de la supervisión al cumplimiento de las medidas provisionales de protección (parte VIII). El hecho de que la CIJ ha, hasta el momento, ligeramente procedido a la determinación de violaciones a medidas provisionales en los procedimientos subsecuentes como en los méritos de sus respectivos casos, en su opinión, no significa que no pueda hacerlo más prontamente, por vía de otra orden de medidas provisionales. La Corte — procede- tiene poderes de monitoreo al cumplimiento de medidas provisionales. Si cualquier circunstancia no prevista ocurre, la CIJ “está empoderada con poderes inherentes o facultés para tomar la decisión que asegure el cumplimiento de tales medidas que ha ordenado, y con ello salvaguardar los derechos en peligro" (para. 45). Esto fortalece la dimensión preventiva de las medidas provisionales, como la supremacía del derecho (prééminence du droit) en el ámbito internacional (para. 46).

23. El siguiente punto examinado por el juez Cançado Trindade es el de la violación de medidas provisionales y la reparación de daños (en sus distintas formas) (parte IX), un punto que no ha pasado desapercibido en el presente fallo de la CIJ en los casos acumulados de "Ciertas actividades" y "Construcción de una carretera": la Corte se refirió a las reparaciones en los casos acumulados, en particular, en su declaración (en el caso "Ciertas 
actividades") de la violación de las medidas provisionales en cuanto a una "adecuada satisfacción al demandante, sin incluir las costas". (En el caso acumulado "Construcción de una carretera"), su declaración sobre la violación de la obligación de conducir un estudio de impacto ambiental en sí misma provee adecuada satisfacción al demandante.

24. La concesión de esta forma de reparación (satisfacción) en los casos acumulados es necesaria y reconfortante. El juez Cançado Trindade agrega que el hecho de que la CIJ no estableció la violación de las medidas provisionales ni indicó nuevas medidas provisionales de una vez en su orden del 16.7.2013 (como debió haber hecho, por las razones explicadas en su opinión disidente) y solo lo hizo en su orden subsecuente del 22.11.2013 da peso a su decisión de no conceder costas. Después de todo — procede-, "la prolongación de los procedimientos (como de las medidas provisionales) se debió a la indecisión de la Corte misma. Por ello, el asunto relevante aquí es, entonces, la reparación (más que las costas) por la violación de las medidas provisionales de protección" (para. 50).

25. En efecto, "violación y deber de reparar vienen juntos"; como señaló en su opinión separada en el caso A. S. Diallo (Guinea c. R. D. Congo) (reparaciones, sentencia del 19.6.2012), "el deber de reparar tiene raíces históricas profundas, que datan de los orígenes del derecho de gentes, y que se hacen presente en el legado de los "padres fundadores de nuestra disciplina"' (para. 51). El deber de reparar — agrega el juez Cançado Trindade- es ampliamente reconocido como general o como derecho internacional consuetudinario, como "el adecuado e indispensable complemento de un hecho internacionalmente ilícito, para que cesen todas las consecuencias que de este se derivan, y asegurar el respeto por el orden legal internacional". Violación y deber de reparación "forman un todo indisoluble" (para. 51). Y concluye, para el caso particular, que:

la interrelación entre violación y deber de reparar tiene presencia también en el ámbito del régimen legal autónomo de las medidas provisionales de protección. La violación de una medida provisional prontamente genera el deber de reparar. Es importante, para que las medidas provisionales logren su plenitud (dentro de su régimen legal), 
mantenerse dispuesto a la reparación —en distintas formas - ante su violación. Reparaciones (de mayor alcance que las costas) por la violación autónoma de medidas provisionales de protección son un elemento central para la consolidación de un régimen legal autónomo de medidas provisionales de protección (para. 52).

26. El juez Cançado Trindade luego llama su atención a la debida diligencia, y a la correlación entre el principio de prevención y el principio de precaución (parte X). Estos son elementos que marcan su presencia en el fallo de la CIJ en los casos acumulados sobre "Ciertas actividades" y "Construcción de una carretera", como lo hicieron en un reciente caso latinoamericano, el de las papeleras del río Uruguay (2010), entre Argentina y Uruguay (paras. 53-54): "Mientras el principio de prevención asume que los riesgos pueden ser objetivamente valorados para evitar el daño, el principio de precaución valora los riesgos frente a incertidumbres, teniendo en cuenta la vulnerabilidad de los seres humanos y del medio ambiente, como la posibilidad de daño irreversible" (para. 55).

27. Posteriormente, él pondera que, "a diferencia de la creencia positivista en la certeza del conocimiento científico", el principio de precaución "está engranado con la debida diligencia, frente a incertidumbres científicas; la precaución, es, actualmente, más necesaria que nunca". "No es sorprendente que algunas convenciones de derecho ambiental le den expresión tanto al deber de prevención como al de precaución, reconociendo la conexión entre ellos, dando bases al deber de conducir un estudio de impacto ambiental", y según lo resuelto por la CIJ en el caso acumulado de "Construcción de una carretera" (para. 56). En el presente fallo — continúa_, la Corte, frente al requisito de debida diligencia para prevenir el daño transfronterizo significativo, se enfocó en la realización de un estudio de impacto ambiental "en el ámbito de un amplio derecho internacional general” (para. 57).

28. El juez Cançado Trindade luego se encamina a detectar el camino hacia un desarrollo progresivo de las medidas provisionales de protección (parte XI), que considera es la mayor lección de la adjudicación en el cas d'espèce, el caso acumulado de "Ciertas actividades". La conformación de un régimen legal autónomo de 
medidas provisionales de protección, con todos sus elementos e implicaciones, debe ser desarrollada más a fondo. Como él ya advirtió en su previa opinión disidente en la orden de la CIJ del 16.7.2013 en los presentes casos acumulados, donde la Corte decidió no indicar nuevas medidas provisionales ni modificar las medidas indicadas en su orden previa del 8.3.2011, él considera necesario reiterar:

Mi tesis, en suma, es que las medidas provisionales, dotadas con una base convencional — como la de la CIJ (bajo el artículo 41 del Estatuto)—, también están dotadas de autonomía, tienen su propio régimen legal, y su incumplimiento genera responsabilidad internacional del Estado, implica consecuencias legales, sin el perjuicio del examen y solución del caso concreto en cuanto al fondo.

[...] Las medidas provisionales de protección general de obligaciones (de prevención para los Estados involucrados), que son distintas de las obligaciones que emanan de las sentencias de fondo de la Corte (y de las reparaciones) de los casos respectivos. Esto nace de su régimen legal autónomo, como yo lo concibo. Existe, en mi opinión, una urgente necesidad actual de refinar y desarrollar conceptualmente este régimen autónomo. [...].

[...] El asunto ante la Corte invita a una postura más proactiva de su parte, no solo a resolver controversias presentadas ante ella, sino también a decir que es el derecho (juris dictio) y con ello contribuir efectivamente a evitar o prevenir el daño irreparable en situaciones de urgencia, para el beneficio de todos los sujetos de derecho internacional, Estados como grupos de individuos y simples particulares. Después de todo, la persona humana (viviendo en armonía con el hábitat natural) ocupa un lugar central en el jus gentium de nuestra época (cit. in. para. 59).

29. El juez Cançado Trindade adiciona que los derechos protegidos por las medidas provisionales de protección no son necesariamente los mismos que aquellos relativos al fondo del caso; y que las obligaciones que nacen de las medidas provisionales son distintas, y adicionales, a aquellas que se deriven después de la subsecuente decisión de la Corte respecto al fondo (para. 61). En caso de violación de las medidas provisionales 
de protección, "la noción de víctima de daño emerge en el marco de las medidas provisionales; daños irreparables pueden, por tal violación, ocurrir en el contexto de la prevención" (para. 61). Siendo así, la "determinación de tal violación no requiere de esperar a la conclusión de los procedimientos de fondo en el caso, particularmente si estos procedimientos se prolongan indebidamente" (para. 63).

30. Adicionalmente, "la determinación de su violación no está condicionada a la existencia de una solicitud para tal efecto por el Estado afectado". La Corte —él concluye en el punto presente- "está totalmente facultada para proceder prontamente en la determinación de la violación sponte sua, ex officio, en el interés de la debida administración de justicia" (para. 64). El refinamiento del régimen legal autónomo de las medidas provisionales de protección (incluyendo reparación en sus distintas formas, como eventuales costas) "puede clarificar este dominio del derecho internacional marcado por la prevención y la debida diligencia, y puede promover el desarrollo progresivo de estas medidas en el derecho internacional contemporáneo, fiel a su dimensión preventiva, para el beneficio de todos los justiciables" (para. 66). Al hacerlo, la jurisprudencia internacional parece estar precediendo a la doctrina legal (para. 66).

31. En la última parte (XII) de su opinión separada, al presentar una recapitulación de sus argumentos, el juez Cançado Trindade pondera que las medidas provisionales proveen, como se ha visto, "tierra fértil para la reflexión en el nivel jurídico-epistemológico. Tiempo y derecho están aquí ineludiblemente juntos, como en otros temas de derecho internacional" (para. 67). Las medidas provisionales implican la dimensión preventiva, "creciendo en su claridad, en el derecho internacional contemporáneo". Las medidas provisionales "han tenido una significativa evolución, pero aún falta largo camino para llegar a su plenitud” (para. 67).

\section{Opinión separada de la jueza Donoghue}

La jueza Donoghue considera que bajo el derecho internacional consuetudinario los Estados tienen una obligación de ejercer la debida diligencia en la prevención del daño transfronterizo significativo. Esta obligación de 
debida diligencia emana de la síntesis de principios básicos del orden legal internacional, en particular, la igualdad soberana y la integridad territorial. Las medidas que un Estado de origen debe tomar para cumplir con esta obligación de debida diligencia dependen de las circunstancias particulares, y pueden incluir el estudio de impacto ambiental, la notificación de los Estados potencialmente afectados y la consulta con esos Estados. Sin embargo, la jueza Donoghue no considera que la Corte esté en posición de prescribir reglas específicas de derecho internacional consuetudinario en relación con estos tres temas. Con respecto a la notificación y la consulta, ella también encuentra reparos sobre la formulación precisa adoptada por la Corte.

\section{Opinión separada del juez Bhandari}

En su opinión separada, el juez Bhandari recuerda que ha votado con la mayoría para decidir que Costa Rica ha violado el derecho internacional al no producir un estudio de impacto ambiental EIA en relación con el omnicomprensivo proyecto de carretera a lo largo del río San Juan. Sin embargo, lamenta la falta de directrices claras en relación con los requerimientos de un EIA bajo el derecho internacional, y procede a recomendar ciertos requisitos mínimos que, en su consideración, deben ser satisfechos al momento de realizar un EIA. Él inicia su análisis con un repaso por las tendencias modernas y varios principios pilares en el derecho internacional ambiental contemporáneo, incluyendo: el principio de desarrollo sostenible, el principio de acción preventiva, comunes globales, el principio de precaución, el principio de quien contamina paga y el concepto de daño trasfronterizo. Él discute después cómo el requerimiento de efectuar un EIA emerge de esos principios. La opinión indica adicionalmente que en la actualidad el régimen del derecho internacional ambiental en relación con el desarrollo de un EIA está disperso a lo largo de una colcha de retazos de diferentes instrumentos internacionales, el cual finalmente no establece con claridad requisitos procedimentales y sustanciales mínimos. Haciendo referencia al Convenio de Espoo y otras fuentes, el juez Bhandari busca extraer ciertas obligaciones básicas relacionadas con la conducción de un EIA que, él cree, deben ser incorporadas en el canon del derecho internacional ambiental. Finalmente, el juez Bhandari llama a las naciones a reunirse para celebrar un tratado internacional que gobierne los requerimientos mínimos de los EIA. De no llegar a crearse ese régimen, él sugiere que las 
naciones podrían querer seguir las sugerencias contenidas en su opinión como "mejores prácticas" para ser aplicadas por los Estados en el cumplimiento de su deber de llevar a cabo EIA transfronterizos.

\section{Opinión separada del juez Robinson}

La opinión separada del juez Robinson explica las razones por las cuales votó en contra del rechazo en el párrafo 229(7) del fallo de todas las otras pretensiones hechas por las partes. El juez Robinson considera que la Corte debió haber decidido explícitamente el alegato de Costa Rica según el cual Nicaragua violó el artículo 2(4) de la Carta de las Naciones Unidas, en vez de decidir, como lo hizo en el fallo, no extenderse en este alegato "dado que el carácter ilícito de estas actividades ya ha sido establecido".

El artículo 2(4) de la Carta de las Naciones Unidas, que prohíbe la "amenaza o el uso de la fuerza contra la integridad territorial o la independencia política de cualquier Estado, o en cualquier otra forma incompatible con los propósitos de las Naciones Unidas", es, en consideración de la Corte, "un pilar de la Carta de las Naciones Unidas". Dada la naturaleza fundacional de la prohibición en el orden internacional, así como el rol previsto para la Corte en el acogimiento de los propósitos de la Carta de las Naciones Unidas, la Corte debe jugar su rol en el fortalecimiento del respeto por la prohibición del uso de la fuerza. En la posición del juez Robinson, la Corte debe desarrollar la práctica de hacer determinaciones expresas y discretas cuando se eleva una reclamación de que la prohibición del uso de la fuerza ha sido violada, a menos que sea de la opinión que la pretensión es flagrantemente inmeritoria o frívola.

El juez Robinson interpreta el "daño sufrido por Costa Rica", discutido en el párrafo 97 del fallo, en el sentido de incorporar cualquier potencial daño sufrido por Costa Rica como resultado de la violación de la prohibición del uso de la fuerza. Él está convencido de que es posible asegurar que el perjuicio será remediado sin un examen de los hechos y circunstancias que rodearon la potencial violación. El juez Robinson es escéptico de que, en el contexto de este caso, la reparación derivada de la violación de Nicaragua de la soberanía territorial pueda remediar el perjuicio sufrido a causa de la violación de la prohibición del uso de la fuerza. La Corte no analizó ninguna equivalencia entre las dos normas, las cuales, en consideración del juez Robinson, sirven a propósitos distintos y reflejan preocupaciones convergentes pero no idénticas. 
La jurisprudencia de la Corte establece que las acciones de un Estado deben alcanzar un determinado umbral antes de ser calificadas como un uso ilícito de la fuerza. Analizar si este umbral ha sido cumplido o no requiere un análisis de gravedad y el propósito de las presuntas acciones ilícitas. La posición del juez Robinson es que la evidencia ante la Corte en este caso demuestra que Nicaragua sí violó la prohibición del uso de la fuerza.

\section{Declaración del juez Gevorgian}

El juez Gevorgian explica en su declaración las razones por las que él votó en contra del párrafo 1 del dispositif, el cual prevé que "Costa Rica tiene soberanía sobre el 'territorio en disputa". En su opinión, esta decisión de la Corte — hecha en respuesta a una pretensión presentada por Costa Rica solo al exponer sus conclusiones finales en el caso sobre "Ciertas actividades" - no era requerida en las circunstancias del caso.

El juez Gevorgian comparte la negativa de la Corte de delimitar el curso de la frontera en el "territorio en disputa" definido por la Corte en sus órdenes de medidas provisionales del 8 de marzo de 2011 y 22 de noviembre de 2023. Sin embargo, él encuentra problemático que la Corte declare la soberanía de Costa Rica sobre un área cuyos límites están lejos de ser claros. En la opinión del juez Gevorgian, la Corte debió evadir esa determinación por dos razones.

Primero, las partes no abordaron el asunto de la ubicación precisa de la boca del río o de la frontera en la costa, como lo indica la mayoría en el párrafo 70 del fallo. Por lo tanto, el juez Gevorgian considera que la Corte no estaba en posición de abordar completamente la pretensión final de Costa Rica.

Segundo, la geografía del área en disputa —en la cual han ocurrido importantes alteraciones geomorfológicas en el último siglo- es altamente inestable. De esta forma, de acuerdo con el juez Gevorgian, la conclusión de la Corte en relación con la soberanía sobre el territorio en disputa puede volverse la fuente de un futuro desacuerdo entre las partes.

\section{Declaración del juez 'ad hoc' Guillaume}

El juez ad hoc Guillaume concuerda con algunas de las determinaciones de la Corte. Sin embargo, él ha expresado su desacuerdo con un punto 
en el caso relativo a "Ciertas actividades llevadas a cabo por Nicaragua en el área de frontera (Costa Rica c. Nicaragua)". Él observa que este caso originalmente se relacionó únicamente con aquellas actividades y que todo lo que Costa Rica estaba buscando era un fallo contra Nicaragua por haber violado su soberanía sobre la parte norte de la Isla Portillos. Fue solo al final de los procedimientos orales que, por primera vez, Costa Rica le pidió a la Corte determinar que tenía soberanía sobre el territorio en disputa. La Corte lo decidió, aunque sin determinar en plenitud los límites de ese territorio.

El juez ad hoc Guillaume recuerda que, de acuerdo con su jurisprudencia, la materia objeto de la disputa está definida por las pretensiones presentadas en la demanda, según lo prevé el artículo 40 del Estatuto. Pretensiones adicionales son admisibles solo si ellas se enmarcan en la materia objeto de la demanda. La única excepción se da cuando las nuevas pretensiones se encuentran implícitas en la demanda, o emergen directamente de la cuestión que constituye la materia objeto de la demanda - Ahmadou Sadio Diallo (República de Guinea c. República Democrática del Congo), fondo, fallo, ICJ Reports 2010, (II), p. 656, citando Ciertas tierras fosfáticas en Nauru (Nauru c. Australia), excepciones preliminares, fallo, ICJ Reports 1992, p. 267-.

El juez ad hoc Guillaume pone de presente que las nuevas pretensiones de Costa Rica han transformado el caso relativo a la responsabilidad del Estado en una disputa territorial. Él considera que esto no es posible, $\mathrm{y}$, por esto, concluye que las nuevas pretensiones fueron extemporáneas y, por ende, inadmisibles. Por esta razón, él votó contra el punto 1 de la cláusula operativa.

El juez ad hoc Guillaume también aclaró su posición en varios otros puntos. En relación con la libertad de navegación en el río San Juan, él observa que Costa Rica citó cinco incidentes que presuntamente habían violado esa libertad. El juez ad hoc Guillaume observa que la Corte aceptó solo dos de estos como probados. Él cree que dos incidentes en un período de siete años, por lamentables que sean, no pueden ser considerados indicativos de la conducta general de Nicaragua.

En el segundo caso, el relativo a la "Construcción de una carretera en Costa Rica a lo largo del río San Juan (Nicaragua c. Costa Rica)”, el juez ad hoc Guillaume indicó que esta carretera no solo fue construida sin realizar un estudio de impacto ambiental previo, sino que además causó un daño real a Nicaragua. Sin embargo, el juez ad hoc Guillaume expresó que Nicaragua no demostró que ese daño fuera "significativo". Dado que este 
umbral jurisprudencial no fue alcanzado, el juez ad hoc Guillaume encuentra que la responsabilidad de Costa Rica se vio comprometida.

\section{Opinión separada del juez 'ad hoc' Dugard}

La obligación de llevar a cabo un estudio de impacto ambiental en relación con una actividad que presenta un riesgo de daño transfronterizo significativo apareció de manera prominente tanto en "Ciertas actividades" como en el caso de la "Construcción de la carretera". La Corte decidió tomar esta obligación como una del "derecho internacional general", pero un escrutinio de este término sugiere que es casi un sinónimo del de "derecho internacional consuetudinario". La obligación de llevar a cabo un estudio de impacto ambiental es una obligación independiente del deber de debida diligencia, que es el estándar de conducta requerido por parte del Estado al efectuar ese análisis. Aunque se ha sugerido que la obligación de realizar un estudio de impacto ambiental no tiene contenido, un análisis de la decisión de la Corte establece la presencia de ciertas reglas inherentes a esa obligación.

Con base en los principios que ha expuesto en relación con el contenido de la obligación de análisis del impacto ambiental, la Corte correctamente decidió que Costa Rica había violado su obligación al no llevar a cabo ese análisis cuando se embarcó en la construcción de la carretera a lo largo del río San Juan. Las circunstancias demuestran claramente que la carretera presentaba un riesgo de daño significativo al medio ambiente de Nicaragua.

La forma en que la Corte manejó el alegato de Costa Rica según el cual Nicaragua no había llevado a cabo un estudio de impacto ambiental adecuado cuando planeó su programa para mejorar la navegabilidad del río San Juan mediante el dragado fue menos satisfactoria. Por lo tanto, disintió en este punto.

Sin examinar la situación fáctica relativa al programa de dragado de Nicaragua cuando este fue planificado en 2006 y el riesgo que representaba para los humedales de Costa Rica, la Corte tersamente declaró que los reportes presentados ante ella y el testimonio de los testigos llamados por las dos partes la llevaban a concluir que el programa de dragado de Nicaragua planeado en 2006 no era tal que generara un riesgo de daño transfronterizo significativo. Un examen cuidadoso de los reportes más relevantes y del testimonio de los testigos me llevan a concluir que estos 
no fundamentan la determinación fáctica de la Corte. En mi opinión, la evidencia demostraba que el dragado del río San Juan representaba un riesgo para los humedales de Costa Rica, los cuales están protegidos por la Convención de Ramsar. La evidencia de uno de los testigos de Nicaragua, según quien el hecho de que una actividad que tenga lugar en la proximidad de un humedal protegido por la Convención de Ramsar era suficiente razón por sí misma para exigir un estudio de impacto ambiental, era particularmente convincente y parece haber sido ignorada por la Corte. Una objeción ulterior al manejo de la Corte en este punto es que no aplicó los principios que ella misma siguió al abordar el reclamo de Nicaragua contra la construcción de la carretera por parte de Costa Rica. Hubo una clara contradicción entre el razonamiento que la Corte aplicó en cada uno de los casos. Finalmente, un análisis de las disposiciones de la Convención de Ramsar sugería que Nicaragua estaba obligada a realizar un estudio de impacto ambiental en este caso.

Sin lugar a dudas, la carretera que Costa Rica construyó a lo largo del río San Juan representaba un riesgo de daño ambiental al río más grande que el representado por el programa de dragado de Nicaragua para los humedales de Costa Rica. Sin embargo, esto no constituía una justificación para el defectuoso análisis de la prueba ni para el razonamiento contradictorio de la Corte. 
